ФЕДЕРАЛЬНАЯ СЛУЖБА ПО ГИДРОМЕТЕОРОЛОГИИ

И МОНИТОРИНГУ ОКРУЖАЮЩЕЙ СРЕДЫ (РОСГИДРОМЕТ)

КЛИМАТИЧЕСКИЙ ЦЕНТР РОСГИДРОМЕТА

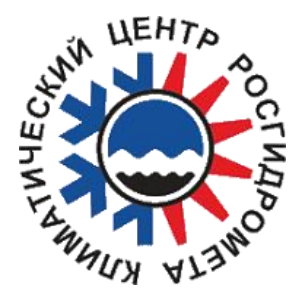

ДОКЛАД

О КЛИМАТИЧЕСКИХ РИСКАХ

НА ТЕРРИТОРИИ РОССИЙСКОЙ ФЕДЕРАЦИИ 
Доклад о климатических рисках на территории Российской Федерации. Санкт-Петербург. 2017. - 106 с.

В настоящей публикации представлены результаты оценки климатических рисков на территории Российской Федерации на основе научных исследований, проводимых учреждениями Федеральной службы по гидрометеорологии и мониторингу окружающей среды (Росгидромета) и обобщенных Климатическим центром Росгидромета.

Материалы настоящей публикации могут быть использованы федеральными и региональными органами государственной власти и другими организациями при планировании мер адаптации к происходящим и ожидаемым изменениям климата.

\section{Под редакцией}

доктора физико-математических наук В. М. Катцова

\section{Авторский коллектив:}

Е. М. Акентьева, Е. И. Александров, Г. В. Алексеев, О. А. Анисимов, Ж. А. Балонишникова, О. Н. Булыгина, В. Ю. Георгиевский, М. Д. Докукин, С. В. Ефримов, Н. Е. Иванов, Х. М. Калов, В. М. Катцов, А. А. Киселев, А. В. Клепиков, М. В. Клюева, Н. В. Кобышева, В. В. Оганесян, В. Н. Павлова, T. В. Павлова, А. А. Постнов, В. В. Стадник, С. А. Солдатенко, Е. И. Хлебникова, А. Л. Шалыгин, И. М. Школьник

ISBN 978-9500833-1-5

(С) Главная геофизическая обсерватория им. А. И. Воейкова (ФГБУ «ГГО»), 2017 


\section{ОГЛАВЛЕНИЕ}

Предисловие ........................................................................ 4

1 Климатические риски: международный контекст............................... 7

2 Изменения климата на территории Российской Федерации................... 12

3 Климатические риски для населения и экономики Российской

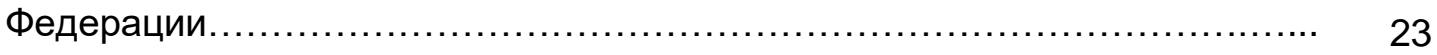

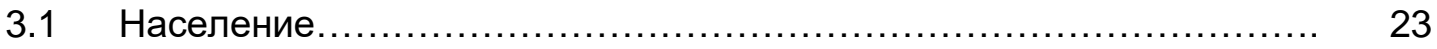

3.2 Национальная инфрраструктура.................................... 31

3.2.1 Состояние зданий и сооружений............................ 31

3.2.2 Транспортная инфрраструктура............................. 33

3.2.3 Энергетическая инфрраструктура............................ 39

3.2.4 Климатические риски для объектов инфраструктуры, связанные с деградацией многолетней мерзлоты............ 45

3.2.5 Климатические риски для объектов инфраструктуры, связанные с динамикой ледников......................... 49

3.3 Сельское хозяйство.................................................... 52

3.4 Водное хозяйство................................................ 62

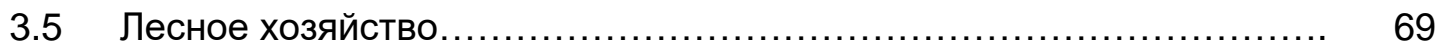

3.6 Морская деятельность............................................. 79

4 Управление климатическими рисками как основа адаптации к изменению

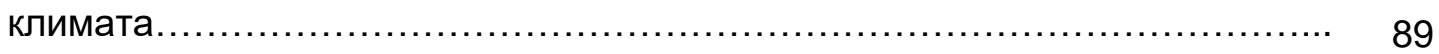

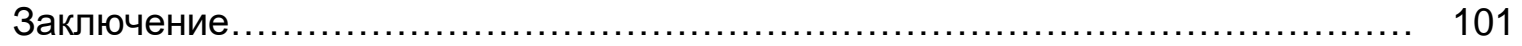

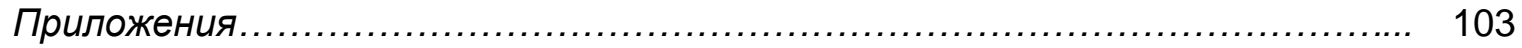




\section{Предисловие}

Всемирный экономический форум (ВЭФ) опубликовал списки глобальных рисков на 2017 г. ${ }^{1}$ Первую позицию в пятерке главных глобальных рисков, ранжированных по вероятности, заняли экстремальные погодные явления. За ними следуют риски массовой вынужденной миграции, стихийные бедствия, крупные теракты и кража данных с сопутствующими видами мошенничества. В списке рисков, ранжированных по масштабу оказываемого воздействия, экстремальные погодные явления уступили лишь оружию массового поражения, опередив нехватку воды, крупные стихийные бедствия и неудачи в борьбе с изменением климата. Эволюция рейтингов угроз, так или иначе связанных с погодно-климатическим фрактором и его изменением, в ежегодных отчетах ВЭФ, публикуемых уже более десятилетия, однозначно указывает на возрастание значимости гидрометеорологического фактора в устойчивом развитии общества.

Одним из наиболее острых вопросов, стоящих перед современной климатической наукой, является вопрос о связи статистики экстремальных погодных явлений в различных регионах мира с глобальным изменением климата.

Выводы Межправительственной группы экспертов по изменению климата $(\text { МгЭИК) })^{2}$ о не вызывающем сомнения глобальном потеплении, которое происходит в настоящее время, продолжают находить подтверждение в данных наблюдений. При этом, согласно данным Росгидромета ${ }^{3}$, на территории России в последние десятилетия потепление климата происходило быстрее и масштабнее, чем в среднем по Земному шару. Так, скорость современного роста глобальной температуры, вызванного в основном увеличением концентрации парниковых газов в атмосфере, составила за последние сорок лет около $0,17^{\circ} \mathrm{C}$ за 10 лет. Температура на территории России растет значительно быстрее $-0,45^{\circ} \mathrm{C}$ за 10 лет, и особенно быстро в Арктике, где скорость роста достигает $0,8^{\circ} \mathrm{C}$ за 10 лет.

Одновременно с этим современная статистика свидетельствует о растущем во всем мире ущербе от опасных погодных и климатических явлений. Данные говорят о том, что $90 \%$ самых тяжелых экономических потерь приходится на опасные гидрометеорологические явления: паводки, наводнения, сильный ветер, ливневые дожди, град, засухи, оставляя таким стихийным бедствиям, как извержения вулканов, цунами и землетрясения, лишь $10 \%$.

По данным Росгидромета за период 1990-2000 гг. на территории России ежегодно фриксировалось 150-200 нанесших ущерб опасных

\footnotetext{
${ }^{1}$ http://reports.weforum.org/global-risks-2017/

${ }^{2} \mathrm{http}: / / \mathrm{ipcc} . \mathrm{ch}$

3 Здесь и далее: Росгидромет, 2017: Доклад об особенностях климата на территории Российской Федерации за 2016 год. Росгидромет, М., 70 с. http://cc.voeikovmgo.ru/images/dokumenty/2017/doc2016.pdf.
} 
гидрометеорологических явлений (ОЯ). В последующие годы их число возросло до 250-300 в год, а, начиная с 2007 года, в среднем один раз в два года число таких ОЯ превышало 400. При этом ОЯ, наблюдаемые в течение двух последних десятилетий, оказались более интенсивными и разрушительными, чем когда-либо.

В частности, в прошедшем 2016 году наиболее значимыми были сильные пожары на юге Восточной Сибири (с начала пожароопасного периода пожары охватили более 305 тыс. га в Иркутской области и более 150 тыс. га в Бурятии), дождевые паводки в Приморском крае в сентябре (были подтоплены населенные пункты, повреждено девять мостов, разрушены дамбы и дороги, местами отсутствовали связь и электроснабжение). Оперативнопрогностическими подразделениями Росгидромета в течение 2016 года было выпущено и доведено до потребителей более двух тысяч штормовых предупреждений. Их оправдываемость составила $94 \%$. На основе штормовых предупреждений принимались превентивные меры, что позволило смягчить последствия стихийных бедствий.

Однако, эффрективные меры по сокращению ущерба от экстремальных погодных явлений зачастую требуют существенно большей заблаговременности, нежели индивидуальные оперативные прогнозы погоды, ограниченные теоретическим пределом предсказуемости. Для принятия действенных упреждающих мер адаптации требуются долгосрочные планы действий, основанные на научно обоснованных перспективных оценках изменения климата, включая оценки изменения статистики экстремальных погодных явлений.

Согласно современным научно обоснованным прогнозам, в том числе приведенным в Оценочных докладах Росгидромета об изменениях климата и их последствиях на территории Российской Федерации (2008 и 2014 гг.) $)^{4}$, наблюдаемые тенденции в изменении климата с высокой степенью вероятности сохранятся и, в ряде аспектов, усугубятся.

В настоящем докладе обобщены основные результаты работ в сфере оценки погодно-климатических рисков для территории России. Определение путей управления этими рисками в дальнейшем должно стать ключевым элементом планирования адаптации к изменениям климата на федеральном и региональном уровнях.

Доклад был подготовлен специалистами НИУ Росгидромета: Главной геофизической обсерватории им. А. И. Воейкова (ФГБУ «ГГО»), Научноисследовательского института Арктики и Антарктики (ФГБУ «ААНИИ»), Всероссийского научно-исследовательского института гидрометеорологической информации - Мирового центра данных (ФГБУ «ВНИИГМИ-МЦД»),

\footnotetext{
${ }^{4}$ Здесь и далее, соответственно: Росгидромет, 2008, и Росгидромет, 2014: Оценочный доклад об изменениях климата и их последствиях на территории Российской Федерации (Бедрицкий А.И. и др., ред.), Росгидромет, 2008, т. 1 (230 с.) и т. 2 (291 c.): http://cc.voeikovmgo.ru/ru/publikatsii/2016-03-22-13-0634; Второй оценочный доклад об изменениях климата и их последствиях на территории Российской Федерации (Катцов В.М., Семенов С.М., ред.), Росгидромет, 2014, 1009 с.: http://cc.voeikovmgo.ru/ru/publikatsii/2016-03-21-16-23-52.
} 
Всероссийского научно-исследовательского института сельскохозяйственной метеорологии (ФГБУ «ВНИИСХМ»), Высокогорного геофизического института (ФГБУ «ВГИ»), Гидрометеорологического научно-исследовательского центра Российской Федерации (ФГБУ «Гидрометцентр России»), Государственного гидрологического института (ФГБУ «ГГИ»), Государственного океанографрического института им. Н. Н. Зубова (ФГБУ «ГОИН») - в рамках Целевой научно-технической программы Росгидромета «Научноисследовательские, опытно-конструкторские, технологические и другие работы для государственных нужд в области гидрометеорологии и мониторинга окружающей среды» за 2014-2016 гг. В докладе также использованы результаты научных исследований, поддержанных грантами РНФ и РФФИ.

Инициатива подготовки настоящего доклада принадлежит В. Г. Блинову в его бытность начальником Управления научных программ, международного сотрудничества и информационных ресурсов Росгидромета. С отдельными главами доклада ознакомились и сделали полезные замечания А. В. Константинов (Санкт-Петербургский научно-исследовательский институт лесного хозяйства), М. Д. Корзухин (Институт глобального климата и экологии Росгидромета и РАН), Б. А. Ревич (Институт народнохозяйственного планирования РАН). Большую работу по подготовке доклада к печати осуществили Е. Л. Махоткина, А. Н. Махоткин и Т. В. Потехина (ФГБУ «ГГО»). Координация подготовки доклада осуществлялась Климатическим центром Росгидромета на базе Главной геофизической обсерватории им. А. И. Воейкова. 


\section{1. Климатические риски: международный контекст}

В конце XX - начале XXI вв. мировое научное сообщество пришло практически к единому мнению о том, что на Земле происходят значимые климатические изменения, которые ощутимо влияют на социальноэкономическое развитие, продовольственную и энергетическую безопасность, урожайность сельскохозяйственных культур, качество жизни, миграцию населения и т. д. Развитие междисциплинарных исследований в рамках крупнейших международных и национальных проектов улучшило понимание причин и факторов воздействия изменения климата на объекты экономики и социальной сореры. Одним из проявлений климатических изменений является увеличение во многих регионах изменчивости и экстремальности климата. Так, по данным Росгидромета ${ }^{5}$, на территории России участились опасные явления погоды, а также инициированные ими техногенные чрезвычайные ситуации. ОЯ, наблюдаемые в течение двух последних десятилетий, оказались более интенсивными и разрушительными, чем когда-либо. В результате возникла безотлагательная необходимость использовать увеличивающийся объем информации о климатической системе как основу для активизации действий по уменьшению опасности бедствий и адаптации к ним.

Современная статистика свидетельствует о растущем во всем мире ущербе от опасных погодных и климатических явлений. Она говорит о том, что 90 \% самых тяжелых экономических потерь приходится не на такие явления природы, как извержения вулканов, цунами и землетрясения, а на более «обыденные»: паводки, наводнения, сильный ветер, ливневые дожди, град, засухи (рис. 1.1).

В своем новом докладе «Погодный бизнес - как компании могут защитить себя от растущей изменчивости погоды» ${ }^{6}$, уделяющем основное внимание растущей важности погодных рисков для компаний, страховщик крупных промышленных рисков Allianz Global Corporate \& Specialty SE (AGCS $)^{7}$ указывает на экономические последствия нестабильных погодных условий и рассказывает, как компании могут защитить себя, используя новые подходы к «управлению погодными рисками». Согласно докладу AGCS, экономические последствия от роста повседневной изменчивости погодных условий значительно превышают и без того огромные суммы убытков, возникающих каждый год по причине стихийных бедствий. По оценкам AGCS, последствия регулярных погодных изменений для экономики Евросоюза могут составить до 406 млрд евро (561 млрд долларов) в год. Для сравнения, за 2012 г. по всему миру произошло 905 стихийных бедствий, 93 \% из которых были связаны с погодой. Они привели к убыткам в размере 170 млрд долларов. Более того,

\footnotetext{
5 Здесь и далее: Росгидромет, 2017: Доклад об особенностях климата на территории Российской Федерации за 2016 год. Росгидромет, М., 70 c. http://www.meteorf.ru/upload/pdf_download/Доклад2016.pdf. ${ }^{6}$ The weather business - how companies can protect against increasing weather volatility. Allianz Global Corporate \& Specialty. 2013, 36 p.

http://www.agcs.allianz.com/assets/PDFs/Reports/2484\%20Allianz\%20Weather\%20Risk\%20LR.pdf

${ }^{7}$ http://www.agcs.allianz.com
} 
наблюдается значительный рост прямых издержек от нестабильности погоды по всему миру. По утверждению AGCS, только в течение трех лет, предшествовавших публикации доклада, страховщики по всему миру выплачивали по 70 млрд долларов в год по убыткам, связанным с экстремальными природными явлениями. В 1980-е годы ежегодная сумма выплат по таким убыткам составляла «только» 15 млрд долларов. К отраслям, наиболее сильно подверженным данным рискам, относятся агропродовольственная отрасль, строительство, торговля, энергетика, туризм и транспортный сектор.

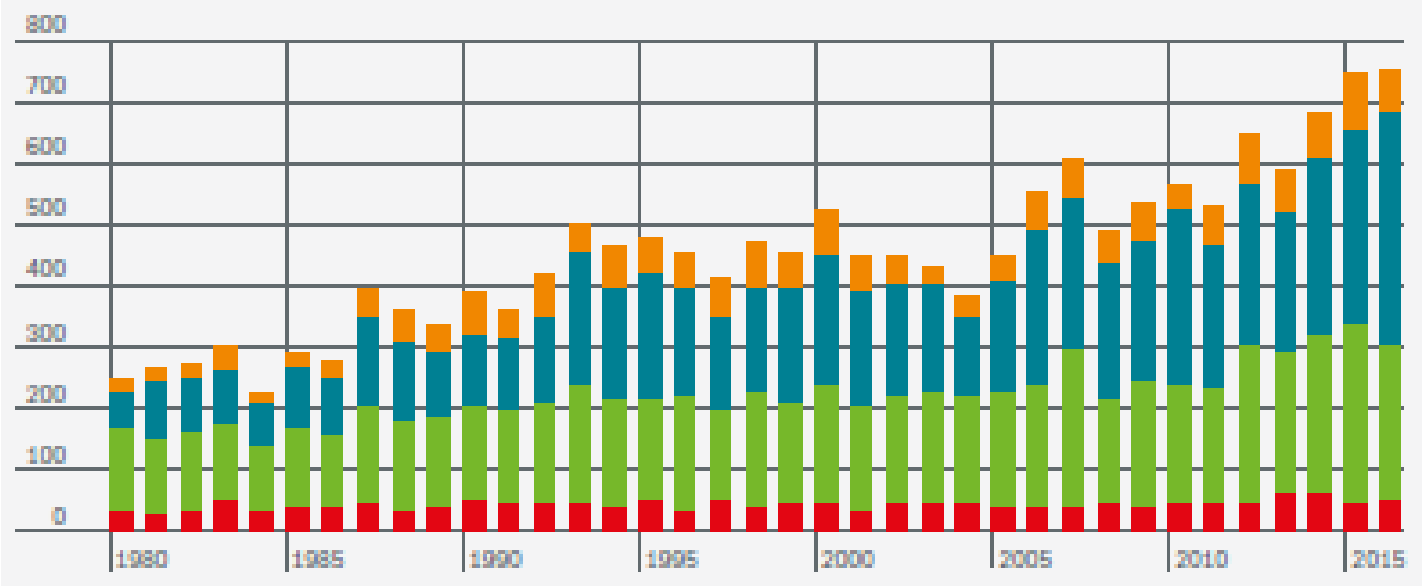

Рис. 1.1 Количество природных катастроф за период 1980-2016 гг. (источник: Munich Re, NatCatSERVICE, www.munichre.com/touch). ${ }^{8}$

\section{- Геофизические явления: землетрясения, цунами, извержения вулканов \\ - Метеорологические явления: тропические штормы, внетропические штормы, конвективные штормы, локальные штормы \\ - Гидрологические явления: речные наводнения, сели (оползни) \\ - Климатические явления: экстремальные температуры, лесные пожары, засухи ${ }^{9}$}

Негативные последствия для денежных оборотов компаний могут возникать даже тогда, когда погодные условия не были экстремальными. Иногда для снижения доходов достаточно необычных, несезонных или просто неожиданных погодных явлений.

В сложившейся ситуации оценка и управление погодно-климатическими рисками становятся особенно актуальными. Решению этой задачи посвящены многие инициативы на международном и национальном уровнях. В 2009 г. на Третьей Всемирной Конференции по климату (ВКК-З) ${ }^{10}$ была принята, а в 2012 г. на внеочередной сессии Всемирного метеорологического конгресса ${ }^{11}$ утверждена Глобальная рамочная основа для климатического обслуживания

\footnotetext{
${ }^{8}$ https://www.munichre.com/site/touch-publications/get/documents_E-

271800065/mr/assetpool.shared/Documents/5_Touch/_Publications/TOPICS_GEO_2016-en.pdf

${ }^{9}$ Приводится классификация явлений, используемая в источнике. Она не является общепринятой.

${ }^{10} \mathrm{http}: / /$ www.gfcs-climate.org/wwc_3

${ }^{11} \mathrm{https} / / /$ library.wmo.int/pmb_ged/wmo_1102_en-p1.pdf
} 
$(\text { ГРОКО })^{12}$, разработанная Всемирной метеорологической организацией (ВМО). В состав ГРОКО включены системы гидрометеорологических наблюдений и моделирования климата, информационная климатическая система и как основной компонент - система обеспечения климатической информацией о меняющемся климате пользователей секторов экономики и социальной сферы. Особенностью ГРОКО, позволяющей определить данный проект как новое стратегическое направление развития климатологии, является ее практическая направленность. Например, такой фундаментальный раздел науки о климате, как моделирование климатической системы, рассматривается в плане возможности интерпретации результатов моделирования для оценки последствий изменения климата. Приоритетными составляющими информационной климатической системы являются интегрируемые в нее экономические методы. Это, прежде всего, оценка факторов климатического риска, количественно характеризующих последствия изменения и изменчивости климата и служащих отправным моментом для управления рисками бедствий и адаптации человеческой деятельности к современному и будущему климату. В 2012 г. МГЭИК подготовила специальный доклад на эту тему. ${ }^{13}$

Хиогская $(2005 \text { г. })^{14}$ и Сендайская $(2015 \text { г. })^{15}$ рамочные программы действий по уменьшению опасности бедствий отмечали приоритетный характер управления климатическими рисками для обеспечения устойчивого развития общества на локальном, национальном и глобальном уровнях. Как следует из приоритетов Сендайской рамочной программы действий ${ }^{16}$, инвестировать в снижение рисков более эффективно, чем оплачивать последствия катастроф.

Вопросами управления климатическими рисками также занимается открытая группа экспертов Комиссии по климатологии ВМО «Взаимодействие с пользователями в целях адаптации к климату и управления рисками». ${ }^{17}$ В 2012 г. при участии этой группы был разработан документ «Совершенствование управления климатическими рисками на местном уровне - технологии, примеры, положительный опыт и рекомендации для членов ВМО». ${ }^{18}$ Он содержал анализ методик управления рисками, обусловленными изменениями и изменчивостью климата, на примерах сельских сообществ. В конце 2017 г. экспертная группа планирует выпуск

\footnotetext{
${ }^{12} \mathrm{http}: / / \mathrm{www} . \mathrm{gfcs}-\mathrm{climate} . \mathrm{org}$

${ }^{13}$ IPCC, 2012: Managing the Risks of Extreme Events and Disasters to Advance Climate Change Adaptation. A Special Report of Working Groups I and II of the Intergovernmental Panel on Climate Change [Field, C.B., V. Barros, T.F. Stocker, D. Qin, D.J. Dokken, K.L. Ebi, M.D. Mastrandrea, K.J. Mach, G.-K. Plattner, S.K. Allen, M. Tignor and P.M. Midgley (eds.)]. Cambridge University Press, Cambridge, UK, and New York, NY, USA, $582 \mathrm{p}$.

${ }^{14} \mathrm{http} / / / \mathrm{www} . u n . o r g / r u / d o c u m e n t s / d e c l \_c o n v / c o n v e n t i o n s /$ hyogoframework.shtml

${ }^{15} \mathrm{http} / / / \mathrm{www}$.unisdr.org/files/43291_russiansendaiframeworkfordisasterri.pdf

${ }^{16} \mathrm{http} / / / \mathrm{www} . u n i s d r . o r g /$ files/43291_russiansendaiframeworkfordisasterri.pdf

${ }^{17} \mathrm{http} / / / \mathrm{www} . \mathrm{wmo} . \mathrm{int} / \mathrm{pages} / \mathrm{prog} / \mathrm{wcp} / \mathrm{ccl} /$ opace/archive/ccl-15/opace4/opace4-ccl-XV.php

${ }^{18}$ Improving Climate Risk Management at Local Level - Techniques, Case Studies, Good Practices and Guidance for World Meteorological Organization Members (Chapter 21) in a book by InTech: Risk Management - Current Issues and challenges (Edited by Nerija Banaitiene, ISBN 978-953-51-0747-7, 584 pages, 2012). https://www.intechopen.com/books/risk-management-current-issues-and-challenges/improvingclimate-risk-management-at-local-level-techniques-case-studies-good-practices-and-guidelin
} 
Руководства по управлению климатическими рисками для национальных гидрометслужб. Его цель - облегчить специалистам-климатологам на местах взаимодействие с потребителями климатической информации для идентификации, оценки и управления климатическими рисками в секторах экономики и социальной сферы.

Концепция климатического риска представлена МГЭИК ${ }^{19}$ в виде схемы (рис. 1.2).

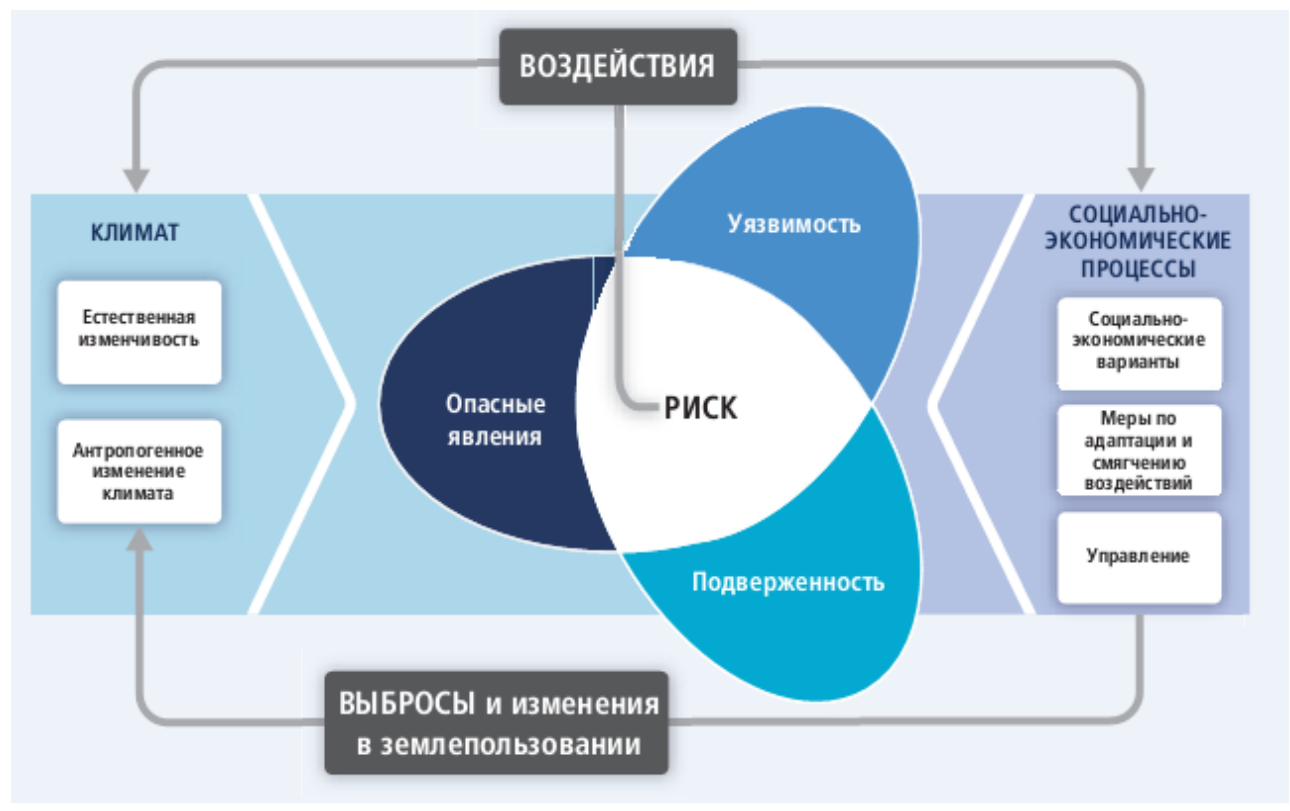

Рис. 1.2 Концепция климатического риска Мгэик. ${ }^{20}$

Таким образом, можно говорить о климатическом риске, если на данной территории наблюдаются опасные или неблагоприятные метеорологические явления и существует некий объект (реципиент риска), находящийся под их вероятным воздействием и уязвимый для них. Перечень опасных явлений, утвержденный местной гидрометслужбой, включает в себя экстремальные значения метеорологических переменных, превышающие заданные потребителем пределы, а также медленные климатические изменения, такие как рост уровня моря, таяние вечной мерзлоты и т. д. В качестве реципиента риска может выступать население, территории, отрасли экономики, экосистемы, технические объекты и процессы.

Глобальные ключевые погодно-климатические риски были определены МГЭИк ${ }^{21}$ на основе экспертных заключений, в которых использовались следующие критерии: «большая величина, большая вероятность или

\footnotetext{
19 Здесь и далее: МГЭИК, 2014а: Изменение климата, 2014: Воздействия, адаптация и уязвимость Резюме для политиков. Вклад Рабочей группы II в Пятый оценочный доклад Межправительственной группы экспертов по изменению климата [Филд К. Б., В. Р. Баррос, Д. Дж. Доккен и др. (редакторы)]. Всемирная метеорологическая организация, Женева, Швейцария, 34 стр. http://ipcc.ch/pdf/assessmentreport/ar5/wg2/ar5_wgII_spm_ru.pdf.

${ }^{20}$ МГЭИК, 2014a.

${ }^{21}$ МГЭИК, 2014a.
} 
необратимость воздействий; сроки воздействий; сохраняющиеся уязвимость или подверженность, способствующие возникновению рисков; или ограниченный потенциал для уменьшения рисков посредством адаптации или смягчения воздействий». Риски характеризовались в диапазоне от весьма низкого до весьма высокого для трех временных интервалов: настоящее время, ближайшая перспектива (до 2030-2040 гг.), долгосрочная перспектива (20802100 гг.). Каждый из этих ключевых рисков является причиной для озабоченности и требует принятия решений:

- риск гибели, увечий или уничтожения средств к существованию в низменных прибрежных зонах и на территориях малых островных государств, связанных со штормовыми нагонами, прибрежными наводнениями и повышением уровня моря;

- системные риски, связанные с аномальными метеорологическими явлениями и обусловливающие нарушение эффрективного функционирования инфраструктурных сетей и жизненно важных систем обслуживания, таких как электроснабжение, водоснабжение, здравоохранение, служба по противодействию чрезвычайным ситуациям;

- риск смертности и заболеваемости в течение периодов экстремальной жары, особенно для уязвимых групп городского населения;

- риск утраты продовольственной безопасности и сбоя в функционировании продовольственных систем, связанный с потеплением, засухой, наводнением, изменчивостью осадков, экстремальными осадками;

- риск потери средств к существованию и дохода из-за недостаточного доступа к питьевой воде и воде для ирригации, а также снижения продуктивности сельского хозяйства в полузасушливых регионах;

- риск утраты морских и прибрежных экосистем, биоразнообразия, экосистемных функций и услуг, которые они обеспечивают в качестве средств к существованию в прибрежных зонах, особенно в тропиках и в Арктике.

Однако до настоящего времени понятие «климатический риск» окончательно не определено, и соответствующая терминология не является общепризнанной. Разные авторы вкладывают неодинаковый смысл в понятие «риск». Например, ряд авторов придают понятию «риск» смысл вероятности угрозы (вероятность смерча, шквала и т. п.), не рассматривая при этом уязвимость объекта. Но даже в тех случаях, когда разные эксперты придерживаются одного и того же смысла, они могут использовать разные термины. Один из них, например, может говорить о риске смерча, другой - о риске разрушения здания (вследствие смерча), а третий стремится оценить риск гибели людей в данном здании вследствие его разрушения. 


\section{2. Изменения климата на территории Российской Федерации}

\section{Наблюдаемые изменения климата}

Выводы МГЭИк 22 о не вызывающем сомнения глобальном потеплении климата, которое происходит в настоящее время, продолжают находить подтверждение в данных наблюдений (рис. 2.1).

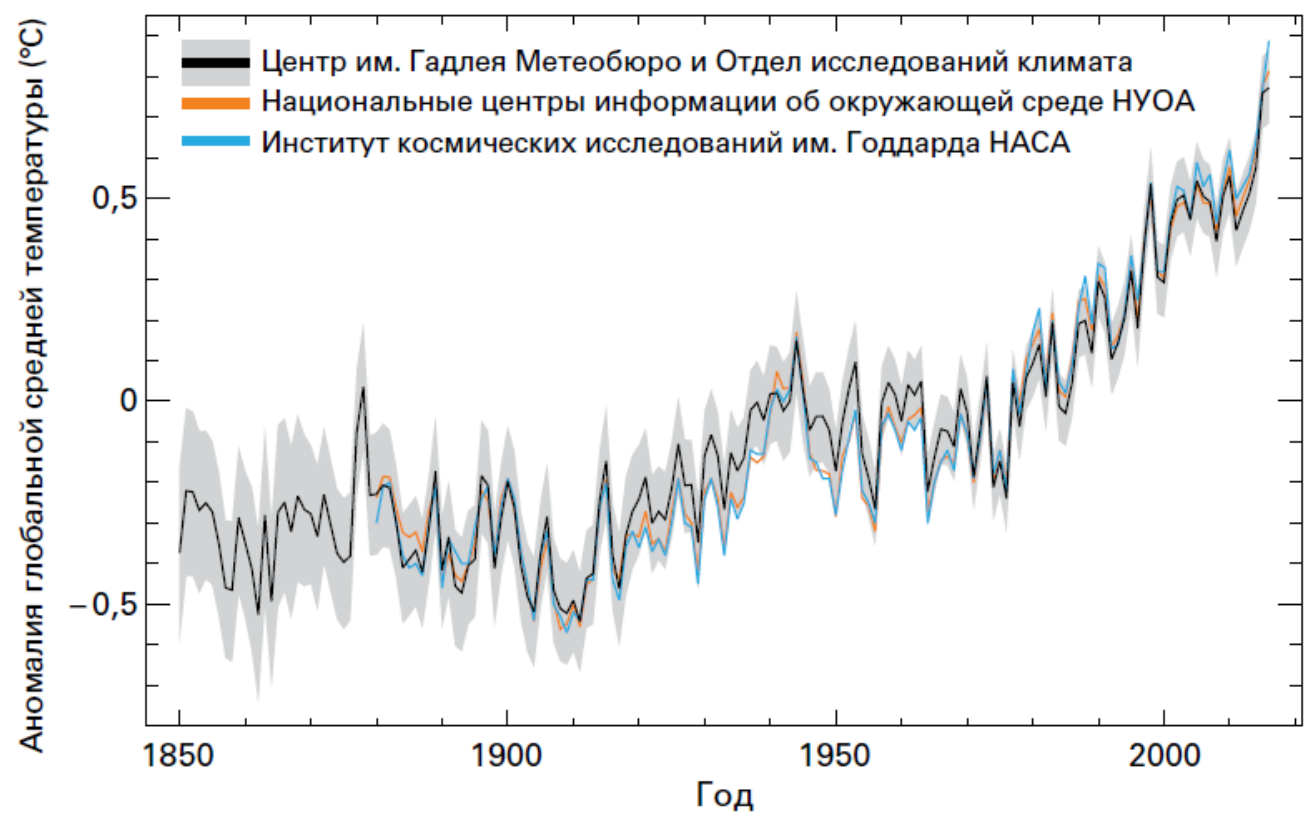

Рис. 2.1 Годовые аномалии средней глобальной температуры (относительно средней за 1961-1990 гг.) за период 1850-2016 гг. Черная линия и затененная серым цветом зона получены на основе анализа HadCRUT4, проведенного Центром им. Дж. Гадлея Метеобюро совместно с Отделом исследований климата Университета Восточной Англии. Серое затенение показывает 95-процентный доверительный интервал оценок. Оранжевая линия - это комплект данных NOAAGlobalTemp, подготовленный национальными центрами информации об окружающей среде Национального управления по исследованию океанов и атмосферы США. Голубая линия - это комплект данных GISTEMP, подготовленный Институтом космических исследований им. Р. Годдарда при Национальном управлении по аэронавтике и исследованию космического пространства (Источник: Центр им. Дж. Гадлея Метеобюро, Соединенное Королевство, и Отдел исследований климата, Университет Восточной Англии, Соединенное Королевство). ${ }^{23}$

При этом роль собственной изменчивости климатической системы, даже в эволюции ее глобальных характеристик, не говоря даже о региональном климате, наглядно продемонстрировала «приостановка» глобального

\footnotetext{
22 Здесь и далее: МГЭИК, 2013: Climate Change 2013: The Physical Science Basis. Contribution of Working Group I to the Fifth Assessment Report of the Intergovernmental Panel on Climate Change [Stocker T.F., D. Qin, G.-K. Plattner, M. Tignor, S.K. Allen, J. Boschung, A. Nauels, Y. Xia, V. Bex and P.M. Midgley (eds.)]. Cambridge University Press, Cambridge, United Kingdom and New York, NY, USA, 1535 p. http://ipcc.ch/report/ar5/wg1/.

23 ВМО, 2017: Заявление ВМО о состоянии глобального климата в 2016 году. Всемирная метеорологическая организация, ВМО-№1189, 24 с.

http://library.wmo.int/opac/doc_num.php?explnum_id=3414.
} 
потепления (известная в англоязычной литературе как «hiatus»). Значительное внимание приостановке было уделено в научной литературе последнего десятилетия, в т. ч. в 5-м Оценочном докладе МГЭИк. ${ }^{24}$ Но уже 2015-й год, отчасти благодаря сильному Эль-Ниньо, нарушил эту 15-летнюю паузу; а ВМО объявила 2011-2015 гг. самым теплым пятилетием за весь период инструментальных наблюдений. ${ }^{25}$ Последующий 2016 г. отмечен еще более высоким, чем 2015 г., значением средней за год средней глобальной приземной температуры воздуха.

Согласно оценкам Росгидромета ${ }^{26}$, на территории России потепление климата происходит примерно в 2,5 раза интенсивнее, чем в среднем по Земному шару: в период 1976-2016 гг. ${ }^{27}$ оно составило 0,45 ${ }^{\circ} \mathrm{C}$ за 10 лет. Наибольшая скорость роста среднегодовой температуры отмечается на побережье Северного Ледовитого океана, особенно в Азиатской части России (АЧР) (на Таймыре - более $+0,9{ }^{\circ} \mathrm{C} / 10$ лет). Весной и осенью максимум потепления наблюдается на побережье Восточно-Сибирского моря, а зимой на северо-западе Европейской части России (ЕЧР). Летом самое быстрое потепление происходит на юге ЕЧР. Весной интенсивное потепление наблюдается в Западной $\left(+0,74{ }^{\circ} \mathrm{C} / 10\right.$ лет) и Средней Сибири $\left(+0,77^{\circ} \mathrm{C} / 10\right.$ лет). В Восточной Сибири очень быстро теплеет весной $\left(+0,72{ }^{\circ} \mathrm{C} / 10\right.$ лет) и осенью (+0,74 ${ }^{\circ} \mathrm{C} / 10$ лет); летом - в Южном и Центральном ФО (+0,76 ${ }^{\circ} \mathrm{C} / 10$ лет и $+0,70{ }^{\circ} \mathrm{C} / 10$ лет). Наименьшее потепление в среднем за год отмечается на юге Западной Сибири. Летом и осенью потепление наблюдается на всей территории России, однако в Сибири (на юге летом и в центре осенью) местами рост очень слаб. Для зимы за указанный период тренд в среднем по территории России положителен $\left(0,32{ }^{\circ} \mathrm{C} / 10\right.$ лет), но статистически незначим. Рост зимней температуры прекратился в середине 1990-х гг., после чего наблюдалось ее убывание; однако в последние пять лет наметилась тенденция к росту.

При этом, согласно Второму оценочному докладу Росгидромета об изменениях климата и их последствиях на территории Российской Федерации ${ }^{28}$, «приостановка» роста средней глобальной приземной температуры практически не проявилась на территории нашей страны: «... в отличие от глобальной ситуации, изменение климата России в целом (в среднем за год и по территории) следует охарактеризовать как продолжающееся потепление, отметив, что тенденция к замедлению потепления пока по данным наблюдений не прослеживается (по крайней мере, во все сезоны, кроме зимы)» (рис. 2.2).

\footnotetext{
${ }^{24}$ МГЭИК, 2013.

${ }^{25}$ BMO, 2016: The global climate in 2011-2015. WMO-No. 1179, 28 p.

${ }^{26}$ Росгидромет, 2017.

271976 год выбран в качестве начала современного потепления в соответствии с ходом глобальной температуры (Росгидромет, 2017).

28 Здесь и далее: Росгидромет, 2014: Второй оценочный доклад об изменениях климата и их последствиях на территории Российской Федерации (Катцов В.М., Семенов С.М., ред.), Росгидромет, 2014, 1009 с.: http://cc.voeikovmgo.ru/ru/publikatsii/2016-03-21-16-23-52.
} 
Значительные изменения коснулись и осадков. В целом по территории России в период 1976-2016 гг. годовые осадки растут - 2,1\% за 10 лет. ${ }^{29}$ Особенно быстро растут весенние осадки - 5,9\% за 10 лет (в Восточной Сибири - до 15-20 \% за 10 лет). Летом на ЕЧР, за исключением северных регионов, наблюдается убывание количества осадков, существенное в южных областях.

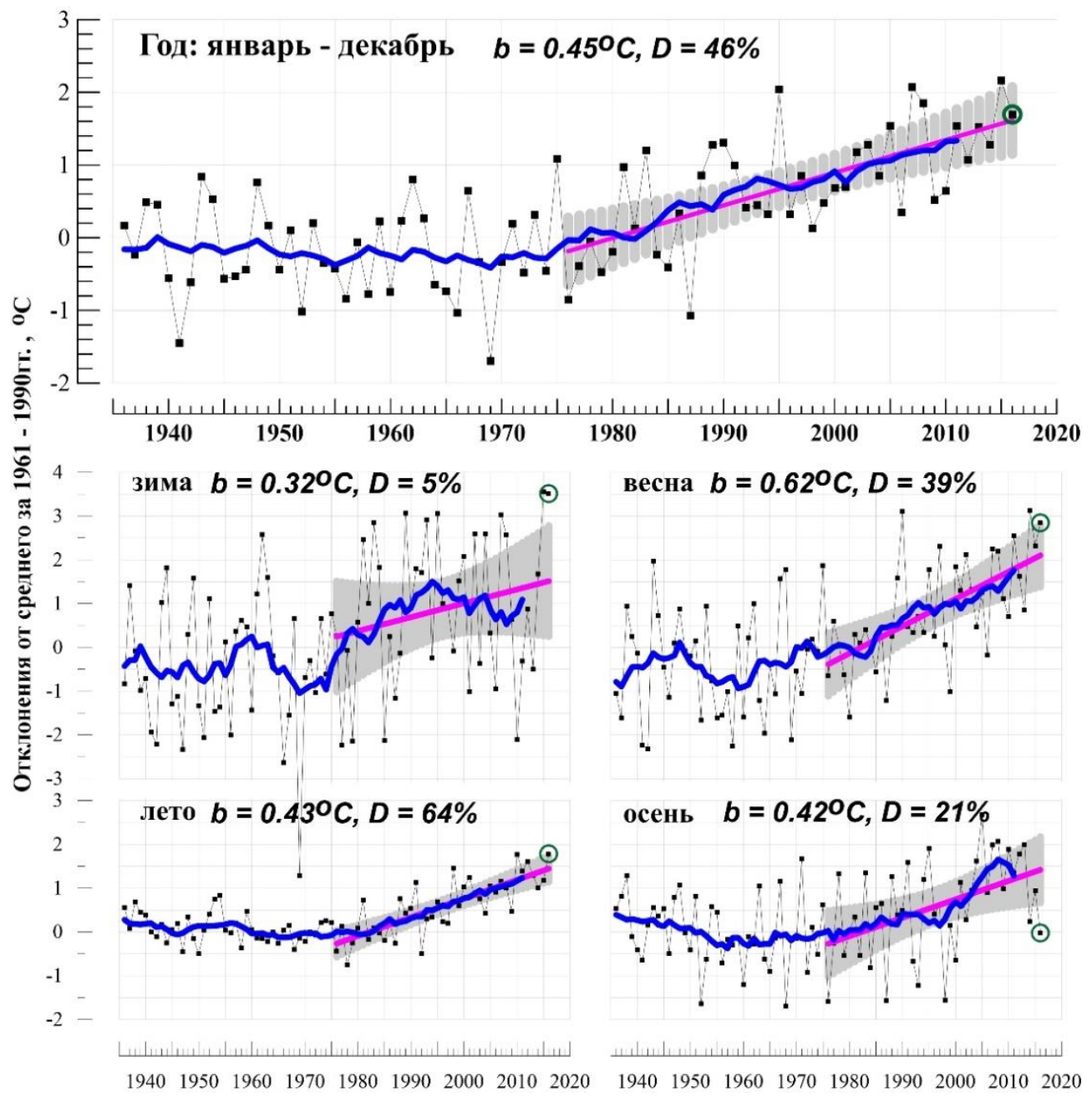

Рис. 2.2 Средние годовые (вверху) и сезонные аномалии температуры приземного воздуха $\left({ }^{\circ} \mathrm{C}\right)$ в период 1936-2016 гг., осредненные по территории России. Аномалии рассчитаны как отклонения от среднего за 1961-1990 гг. Показаны также 11-летнее скользящее среднее, линейный тренд за 1976-2016 гг. с 95\%-й доверительной полосой; b - коэфффициент тренда ( ${ }^{\circ} \mathrm{C} / 10$ лет), D - вклад тренда в суммарную дисперсию (\%). ${ }^{30}$

Тенденция уменьшения продолжительности залегания снежного покрова обнаружена на большей части ЕЧР, на севере и юге Западной Сибири, Таймыре и северо-западе Республики Саха (Якутия). В среднем для России число дней со снежным покровом сокращается на 1,01 дня за 10 лет. Сохраняется тенденция увеличения числа дней со снежным покровом в Забайкалье, на северном побережье Охотского моря, на южном и центральном

\footnotetext{
${ }^{29}$ Росгидромет, 2017.

${ }^{30}$ Росгидромет, 2017.
} 
Урале. Отмечено увеличение максимальной за зиму высоты снежного покрова на севере Западной Сибири, на побережье Охотского моря и дальневосточном юге, в центре ЕЧР, в Чукотском AO и на юге Камчатки. Уменьшение максимальной за зиму высоты снежного покрова зафиксировано на отдельных станциях на севере ЕЧР, севере Камчатского края, северо-западе Республики Саха (Якутия).

Наблюдается рост максимального за зиму запаса воды в снежном покрове в центральных районах ЕЧР, северных и южных районах Западной Сибири, на Камчатке, Сахалине и в Приморье. В лесах на территории России преобладают тенденции к уменьшению максимального за зиму запаса воды в снежном покрове (примерно на 2 мм за 10 лет). В то же время, положительные тренды наблюдаются в южных районах Хабаровского края, в Приморье и на Сахалине. На Дальнем Востоке запас воды в снежном покрове в лесах увеличивается более чем на 7 мм за 10 лет.

Годовой сток большинства крупнейших рек России в последнее тридцатилетие в среднем выше, чем в предшествующее. Значительно увеличилась водность Волги, а также крупных рек, впадающих в Северный Ледовитый океан. Основной причиной роста стока рек зимой на ЕЧР, повидимому, является как рост количества осадков, так и рост повторяемости зимних оттепелей. В Приморье и на Северном Кавказе увеличиваются частота и рост высоких уровней воды при дождевых паводках. Возрастают также частота и мощность наводнений, обусловленных заторами льда на реках Восточной Сибири.

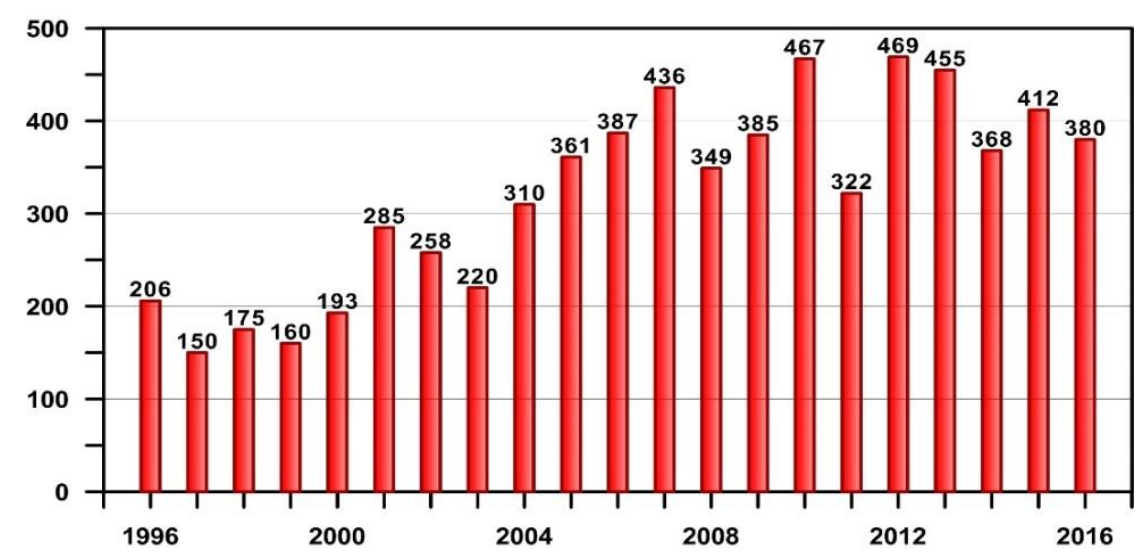

Рис. 2.3 Суммарное за год число гидрометеорологических опасных явлений на территории России, нанесших значительный ущерб экономике и населению, 1996-2016 rr. ${ }^{31}$

При некотором снижении количества непредусмотренных опасных гидрометеорологических явлений, включая гидрологические и агрометеорологические, нанесших значительный ущерб отраслям экономики и жизнедеятельности населения, их общее ежегодное количество в последнее

\footnotetext{
${ }^{31}$ Росгидромет, 2017 (версия рисунка для настоящего доклада подготовлена Т. Р. Жемчуговой).
} 
десятилетие остается неизменно высоким по сравнению с предыдущим десятилетием (рис. 2.3).

В последние десятилетия на многих участках криолитозоны происходит рост температуры верхнего слоя многолетнемерзлых грунтов, а в отдельных регионах отмечается увеличение глубины сезонного протаивания. В то же время, наблюдения на геокриологических стационарах демонстрируют неоднозначные результаты в разных регионах России.

Особую тревогу вызывает скорость таяния ледяного покрова Северного Ледовитого океана. Рекордный минимум площади морского льда за без малого четыре десятилетия спутниковых наблюдений был достигнут в 2012 г. $\left(3,39 \times 10^{6} \mathrm{kм}^{2}\right)$, а средняя скорость этого сокращения по отношению к периоду 1981-2010 гг. в 2016 г. достигла 13,3 \% за десятилетие. ${ }^{32}$

\section{Причины наблюдаемых изменений климата}

Расширяющийся круг исследований ${ }^{33}$, использующих фрормальные статистические методы выделения вклада отдельных внешних воздействий в наблюдаемое глобальное потепление, показывает, что вклад антропогенного роста атмосферной концентрации парниковых газов в температурный тренд с середины XX в. был наибольшим (больше наблюдаемого тренда), а суммарное воздействие остальных фракторов только ослабляло рост температуры. В частности, согласно МГЭИК ${ }^{34}$, нет оснований рассматривать изменение солнечной активности и связанные с нею изменения солнечной радиации на верхней границе атмосферы как причину наблюдаемого потепления климата. Гипотезы о доминирующей роли других естественных климатических факторов в наблюдаемых температурных изменениях, в том числе предположение, что нынешнее потепление климата является проявлением долгопериодной естественной изменчивости, не находят надежных научных подтверждений.

Статистический анализ позволил (с разной степенью достоверности) обнаружить антропогенное влияние не только на температуру приземного воздуха, но и на другие характеристики климатической системы, в частности, на вертикальный профиль температуры атмосферы, на частоту и интенсивность климатических экстремумов, а также на изменение теплозапаса Мирового океана. В последние десятилетия наблюдается одновременное увеличение запаса энергии основных компонентов климатической системы Земли. Причем амплитуда и пространственная структура наблюдаемого потепления в различных компонентах соответствуют ожидаемому по модельным расчетам отклику климатической системы Земли на антропогенное воздействие в виде роста концентрации парниковых газов в атмосфрере.

\footnotetext{
${ }^{32}$ Fetterer, F., K. Knowles, W. Meier and M. Savoie. 2016, updated daily. Sea Ice Index, Version 2. Boulder, Colorado USA. NSIDC: National Snow and Ice Data Center. doi: http://dx.doi.org/10.7265/N5736NV7.

33 См., например, Спорышев П.В., Катцов В.М., Мелешко В.П., Алексеев Г.В., Кароль И.Л., Мирвис В.М., 2014: Причины наблюдаемых изменений климата. Труды Главной геофизической обсерватории им. А.И. Воейкова, вып. 574, с. 39-124.

${ }^{34}$ МГЭИК, 2013.
} 
Что касается ожидаемых в XXI в. изменений климата, то, согласно МГЭИК ${ }^{35}$, средняя глобальная температура будет повышаться при всех сценариях радиационного воздействия. ${ }^{36}$ Для различных сценариев антропогенного воздействия наиболее вероятные оценки увеличения глобальной температуры в 2081-2100 гг. по отношению к 1986-2005 гг. для 5-95 \% общего числа моделей будут составлять: 0,2-1,8 ${ }^{\circ} \mathrm{C}$ (RCP2.6), 1,0-2,6 ${ }^{\circ} \mathrm{C}$ (RCP4.5), 1,3-3,2 ${ }^{\circ} \mathrm{C}$ (RCP6.0), 2,6-4,8 ${ }^{\circ} \mathrm{C}$ (RCP8.5). Различия в количестве осадков, выпадающих во влажных и засушливых регионах, а также в течение влажного и сухого сезонов, будут увеличиваться, хотя в ряде регионов могут быть исключения. Высока вероятность того, что в течение XXI в. меридиональная циркуляция в Атлантическом океане будет ослабевать, однако ее резкие изменения или остановка крайне маловероятны. Уровень Мирового океана в период с 2081 по 2100 г. по сравнению с концом XX в., вероятно, повысится в диапазонах от 0,26-0,55 м (RCP2.6) до 0,45-0,82 м (RCP8.5), а закисление океана будет продолжаться.

Все без исключения современные климатические модели дают потепление климата России в XXI в., заметно превышающее среднее глобальное потепление. Наибольший рост приземной температуры ожидается зимой, причем он усиливается к северу, достигая максимальных значений в Арктике. Летом, напротив, зональность потепления практически не выражена. Уже в начале XXI в. потепление климата в большинстве регионов России превышает стандартное отклонение, характеризующее межмодельный разброс оценок. C середины XXI в. количественные различия между картинами потепления, отвечающими разным сценариям, быстро нарастают.

Изменения средней летней температуры на территории России к середине XXI в. составляют, по отношению к концу $X X$ в., от 2-3 ${ }^{\circ} \mathrm{C}$ для сценария RCP2.6 до $3-4{ }^{\circ} \mathrm{C}$ для сценария RCP8.5. K концу XXI в. различия между сценариями существенно возрастают - от 3-4 ${ }^{\circ} \mathrm{C}$ для сценария RCP4.5 до 6-7 ${ }^{\circ} \mathrm{C}$ для сценария RCP8.5. Зимой и сами значения потепления, и различия между сценариями - значительно большие. В середине XXI в. быстрый рост зимней температуры охватывает все большую часть территории России,

\footnotetext{
${ }^{35}$ МГЭИК, 2013

36 Для перспективных оценок изменений климата, получаемых на основе расчетов с климатическими моделями, основное значение имеют сценарии эволюции содержания парниковых газов и аэрозолей в атмосфере в будущем, а порождающие ее социально-экономические условия не используются непосредственно в модельных расчетах. С этой целью применяется индекс радиационного воздействия, отражающий степень внешнего (антропогенного) воздействия на климатическую систему. В системе сценариев, широко используемой мировым научным сообществом в последние годы, основной исходной характеристикой является эволюция атмосферных концентраций радиационно активных примесей в будущем (т. н. «Representative concentration pathways»-RCP) и их радиационное воздействие к концу XXI века. Индекс сценария соответствует величине глобального антропогенного радиационного воздействия, достигаемого в 2100 г., а именно: 2,6; 4,5; 6,0 и 8,5 Вт/м² - RCP2.6, RCP4.5, RCP6.0 и RCP8.5 соответственно. Эти сценарии сфокусированы на антропогенных выбросах и не включают изменения природных факторов, таких как солнечное или вулканическое воздействия или естественные выбросы парниковых газов. Подробнее см. van Vuuren D.P., J.A. Edmonds, M. Kainuma, K. Riahi, A.M. Thomson, K. Hibbard, G.C. Hurtt, T. Kram, V. Krey, J-F. Lamarque, T. Masui, M. Meinshausen, N. Nakicenovic, S.J. Smith and S. Rose, 2011: The representative concentration pathways: an overview. Climatic Change, 109: 5-31. doi: 10.1007/s10584-011-0148-z.
} 
особенно по мере приближения к арктическому побережью, где для сценария RCP8.5 потепление достигает, в основном, 5-6 ${ }^{\circ} \mathrm{C}$. К концу века повышение зимней температуры для сценария RCP4.5 на территории России составляет от 3-4 ${ }^{\circ} \mathrm{C}$ на юге до $6-7{ }^{\circ} \mathrm{C}$ на севере. Для сценария RCP8.5 соответствующий разброс в конце XXI в. составляет от $5-8{ }^{\circ} \mathrm{C}$ на юге до $10-12{ }^{\circ} \mathrm{C}$ и более на севере.

B XXI в. осадки на территории России, в целом, будут возрастать, причем наиболее значительный их рост ожидается зимой. Географические распределения будущих изменений количества осадков зимой и летом существенно различаются между собой. Зимой увеличение количества осадков ожидается на всей территории России. В начале XXI в. рост количества осадков мал, а к середине века он усиливается, особенно в восточных и северных регионах России. К середине XXI в. наименьшие (в среднем по ансамблю моделей) изменения количества летних осадков отмечаются на юге ЕЧР, где даже проявляется тенденция к их уменьшению. Рост количества летних осадков наиболее значим, главным образом, на севере и востоке России. Изменения влажностного режима на территории России проявляются и в изменениях годового суммарного поверхностного стока: в частности, на юге ЕЧР - в Южном и Северо-Кавказском федеральных округах - ожидается усугубление засушливых (в среднем за год) условий. ${ }^{37}$

Вследствие глобального потепления возможны изменения частоты и (или) интенсивности экстремальных явлений погоды. ${ }^{38}$ Годовые максимумы и минимумы температуры воздуха увеличиваются на большей части территории России; во все сезоны преобладает увеличение числа суток с аномально высокой температурой воздуха и уменьшение числа суток с экстремально низкой ночной температурой воздуха.

Особенностью этих изменений для приземной температуры воздуха (рис. 2.4) является бо́льший рост годового минимума температуры по сравнению с ее годовым максимумом. ${ }^{39}$

На протяжении XXI В. на территории России вероятно нарастание «резкости» выпадения осадков в виде отдельных ливней или снегопадов, рост количества сильных паводков и наводнений, штормовых ветров, колебаний погоды в виде череды холодных и теплых периодов.

На большей части ЕЧР зимой ожидается увеличение числа суток с аномально большим количеством осадков, а летом, напротив, их уменьшение. ${ }^{40}$ Это в целом согласуется с прогнозируемыми изменениями количества осадков высокой интенсивности для указанных сезонов (рис. 2.5): в среднем за летний сезон, в отличие от зимнего, на значительной части региона ожидается снижение интенсивности экстремальных осадков (это, однако, не означает, что в отдельные дни количество экстремальных осадков летом не может перекрывать исторические максимумы).

\footnotetext{
${ }^{37}$ Более подробные количественные оценки можно найти в Росгидромет, 2014

${ }^{38}$ МГЭИК, 2013; Росгидромет, 2014.

${ }^{39}$ МГЭИК, 2013.

${ }^{40}$ Росгидромет, 2014.
} 
A)

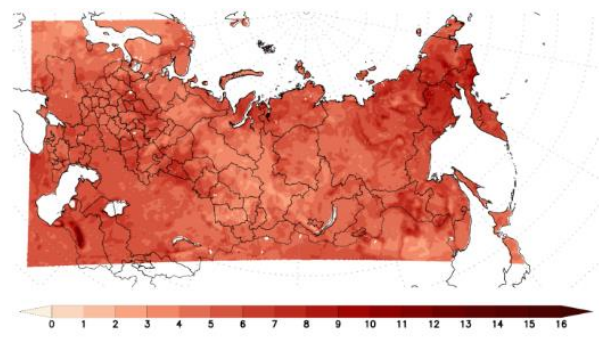

Б)

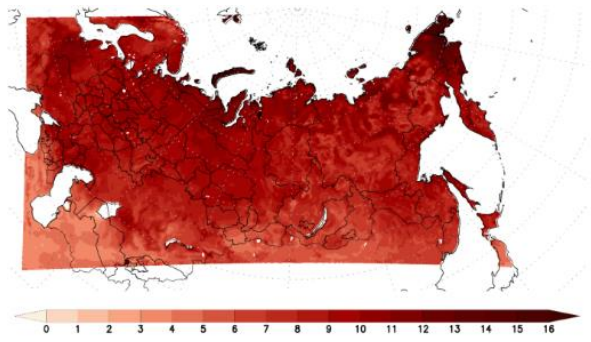

B)

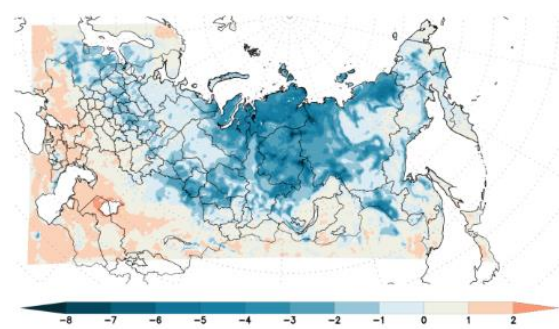

Г)

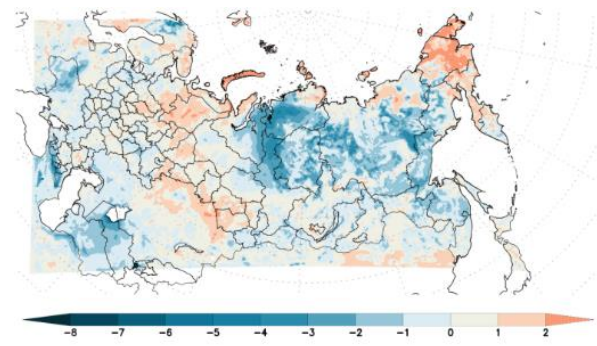

Рис. 2.4 Верхняя (А, Б) и нижняя (В, Г) границы диапазонов изменений годовых максимума (A, B) и минимума (Б, Г) температуры воздуха у подстилающей поверхности в 2050-2059 гг. в ансамбле расчетов с помощью региональной климатической модели ГГО (50 членов) для сценария RCP8.5. Изменения температуры даны в ${ }^{\circ} \mathrm{C}$ относительно базового периода (1990-1999 гг.). ${ }^{41}$

A)

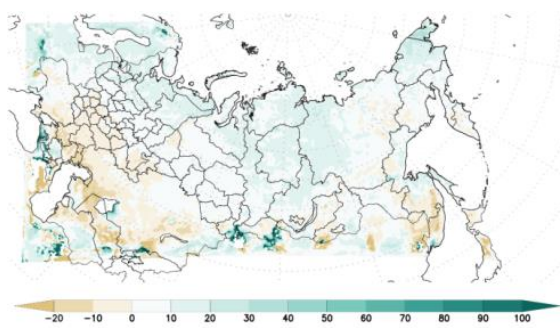

Б)

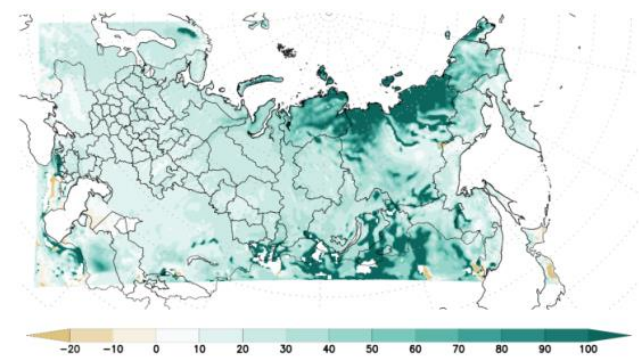

B)

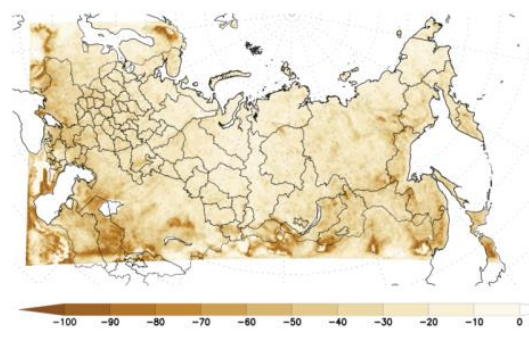

Г)

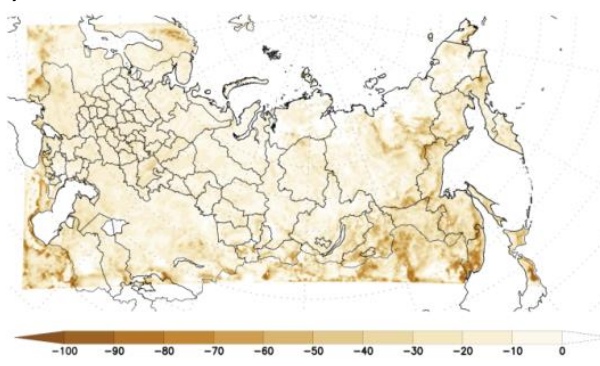

Рис. 2.5 То же, что на рис. 2.4, но для 95-го процентиля осадков летом (А, В) и зимой (Б, Г) В 2050-2059 гг. Изменения осадков даны в \% относительно базового периода $(1990-1999 \text { гг. })^{42}$.

\footnotetext{
${ }^{41}$ Катцов В.М., Школьник И.М., Ефимов С.В., 2017: Перспективные оценки изменений климата в российских регионах: детализация в физическом и вероятностном пространствах. Метеорология $u$ гидрология. № 7, с. 68-80.

42 Катцов В.М., И.М. Школьник, С.В. Ефимов, 2017: Перспективные оценки изменений климата в российских регионах: детализация в физическом и вероятностном пространствах. Метеорология $u$ гидрология. № 7, с. 68-80.
} 
Статистически значимые региональные изменения длительности волн тепла и холода (рис. 2.6) ожидаются на значительной части территории России уже к середине XXI в. и существенно усиливаются к его концу, распространяясь почти на всю территорию страны. Ожидается также более быстрое сокращение длительности зимних волн холода по сравнению с увеличением продолжительности волн тепла летом.

A)

B)

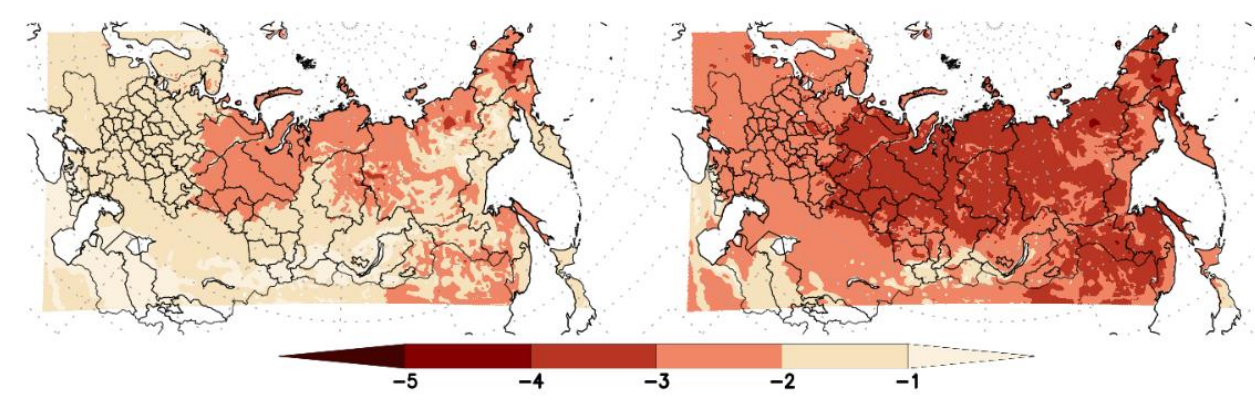

Б)

Г)

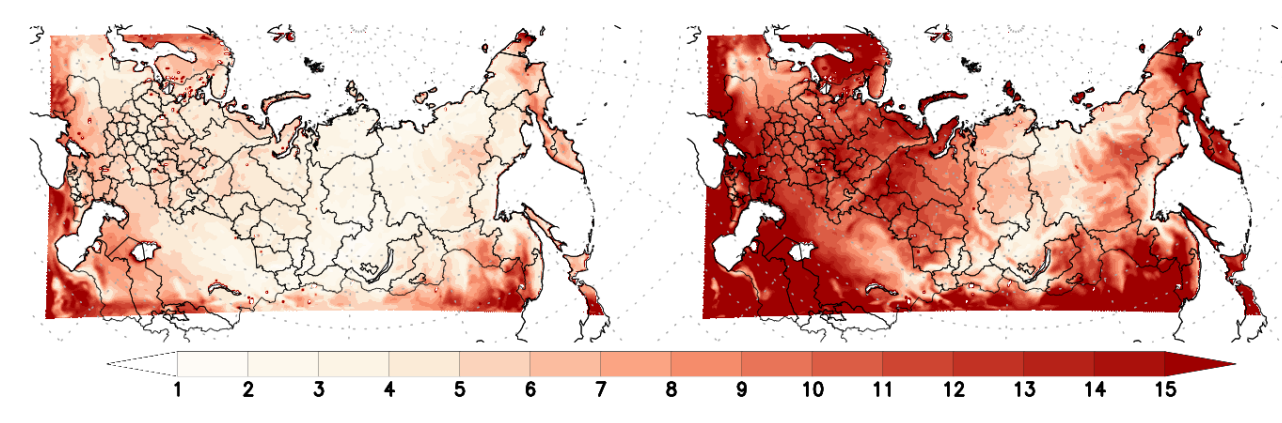

Рис. 2.6 Средние изменения длительности волн холода зимой (A, В) и волн тепла летом (Б, Г) в 2050-2059 гг. (А, Б) и в 2090-2099 гг. (В, Г) по отношению к базовому периоду (1990-1999 гг.), рассчитанные с помощью региональной климатической модели ГГО по ансамблю из 50 членов. Сценарий МГэИК RCP8.5. Волны тепла (холода) рассчитываются здесь как максимальные за сезон непрерывные периоды (не менее 6 суток) с температурой воздуха у подстилающей поверхности выше (ниже) порогового среднего климатического значения температуры 90-го (10-го) процентиля в данной точке. ${ }^{43}$

Для приземной температуры воздуха (несмотря на повышение еe в среднем) в отдельные годы в середине, а в некоторых случаях и в конце XXI в., может отмечаться понижение даже по отношению к базовому периоду - в силу собственной изменчивости климата (рис. 2.7). Иными словами, экстремально холодные периоды в «теплеющем» климате будут отмечаться еще, по крайней мере, несколько десятилетий, и это не противоречит теории антропогенного потепления.

\footnotetext{
${ }^{43}$ Катцов В.М., Школьник И.М., Ефимов С.В., 2017: Перспективные оценки изменений климата в российских регионах: детализация в физическом и вероятностном пространствах. Метеорология $u$ гидрология. № 7, с. 68-80.
} 

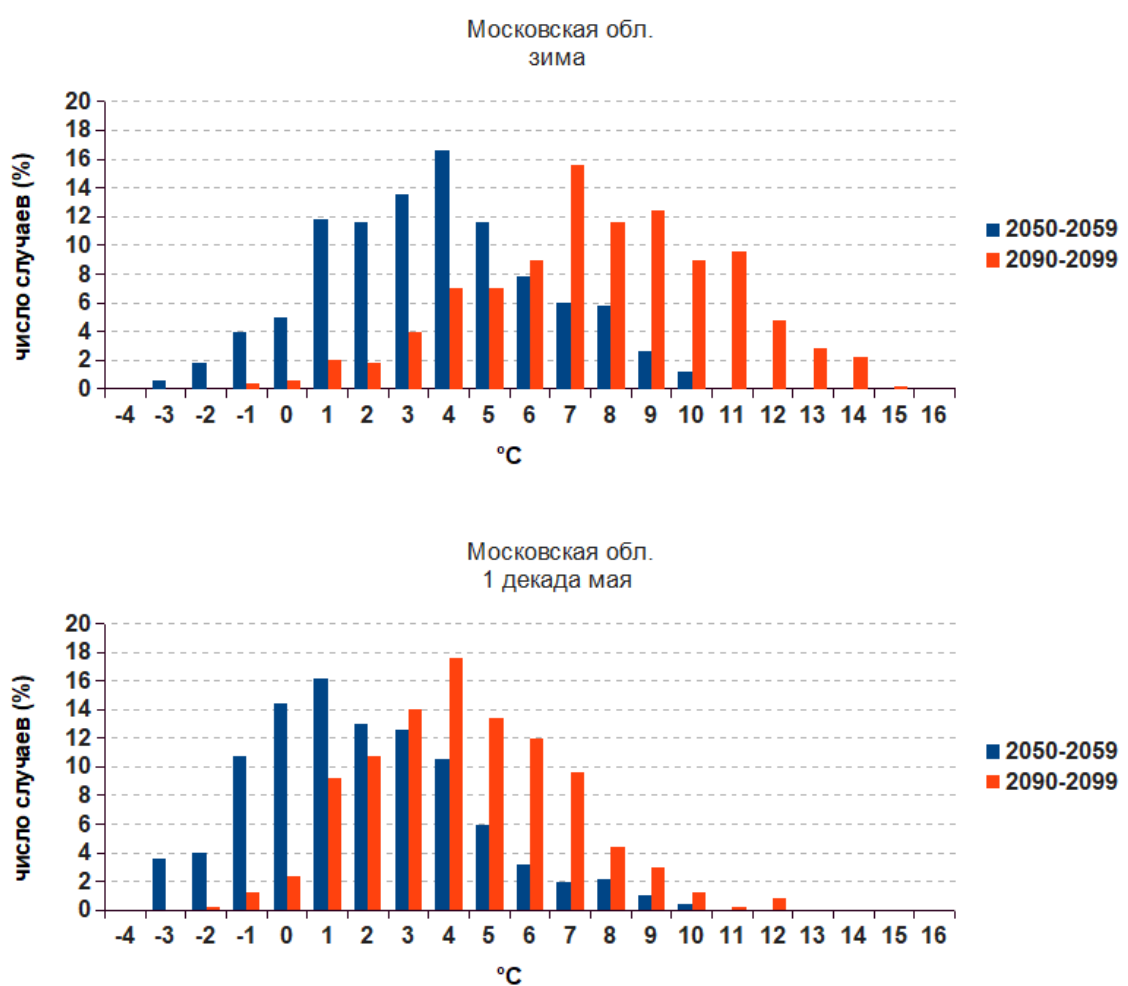

Рис. 2.7 Распределения изменений средней за сезон температуры приземного воздуха в Московской области для зимы (вверху) и первой декады мая (внизу), построенные по ансамблю из 50 членов расчетов с помощью региональной климатической модели ГГО для середины и конца XXI в. - по 500 годам для каждого временного периода. По оси абсцисс отложены градации изменения температуры $\left({ }^{\circ} \mathrm{C}\right)$, по оси ординат - количество «попаданий» средней по региону оценки изменения температуры в соответствующую градацию в процентах. Синим цветом показано распределение изменений температуры для середины XXI В. (2050-2059 гг.), красным - для конца XXI В. (2090-2099 гг.) по отношению к базовому периоду (1990-1999 гг.).

Расчеты будущих изменений снежного покрова суши указывают на сокращение его площади с различной скоростью, в зависимости от рассматриваемого сценария. Скорость сокращения площади снежного покрова до середины XXI в. по сценариям RCP4.5 и RCP8.5 примерно одинаковая, но во второй половине XXI в. для сценария RCP4.5 она замедляется, а для сценария RCP8.5 увеличивается. ${ }^{44}$

При реализации сценария RCP4.5 сохранение приповерхностной мерзлоты в границах современной зоны прерывистой мерзлоты маловероятно, a в рамках сценария RCP8.5 условия, благоприятные для существования многолетней мерзлоты, сохранятся на территории России только в Арктике и на Восточно-Сибирском нагорье. ${ }^{45}$

Что касается будущих изменений площади и толщины морского льда в Арктике, то соответствующие современные модельные оценки согласуются

\footnotetext{
${ }^{44}$ Павлова Т.В., Катцов В.М., Пикалева А.А., Спорышев П.В., Говоркова В.А., 2013: Снежный покров и многолетняя мерзлота в моделях CMIP5: оценки современного состояния и его возможных изменений в 21-м веке. Труды Главной геофизической обсерватории им. А.И. Воейкова, вып. 569, с. 38-61.

${ }^{45}$ Slater, A.G. and D.M. Lawrence, 2013: Diagnosing Present and Future Permafrost from Climate Models. J. Climate, 26, 5608-5623, https://doi.org/10.1175/JCLI-D-12-00341.1.
} 
качественно, однако разброс их весьма значителен. Оценки, предполагающие исчезновение многолетнего морского льда к середине XXI в. при реализации «жестких» сценариев антропогенного воздействия, на сегодняшний день не представляются нереалистичными (рис. 2.8).

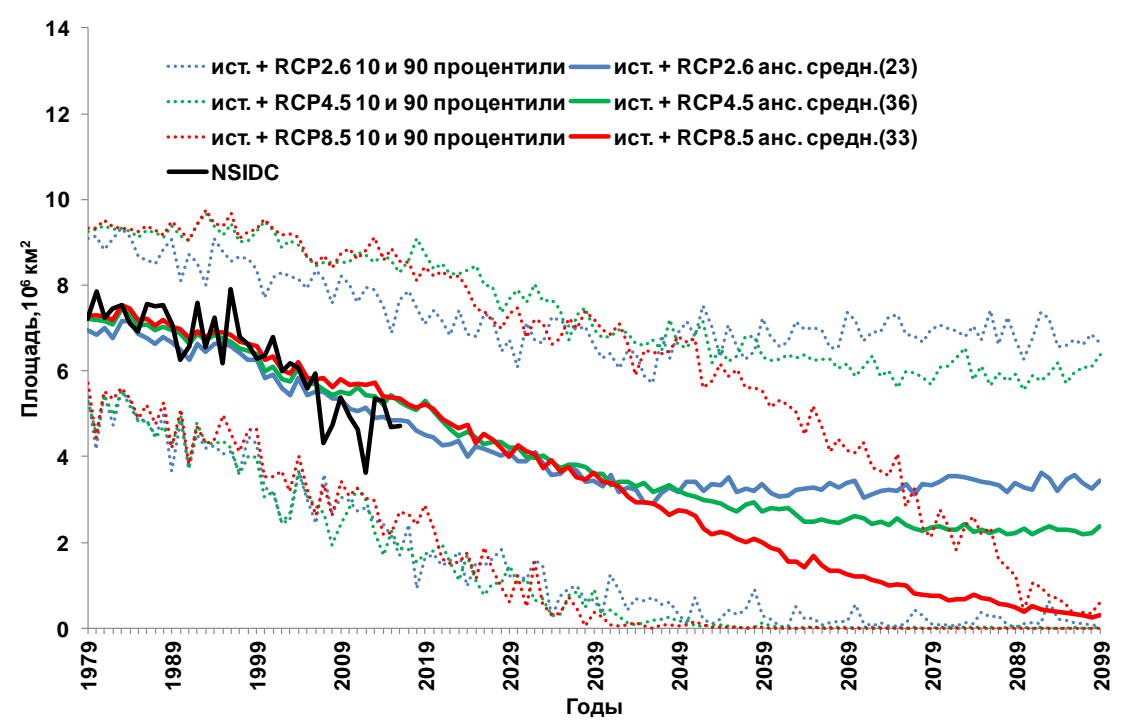

Рис. 2.8 Эволюция площади морского льда в период 1979-2099 гг. в Северном полушарии в сентябре по данным моделей CMIP5 для трех сценариев RCP: RCP2.6, RCP4.5 и RCP8.5 (голубая, зеленая и красная сплошные линии соответственно), а также межмодельный разброс в пределах 10-го и 90-го процентилей (голубая, зеленая и красная пунктирные линии соответственно) ${ }^{46}$. Для периода 1979-2005 гг. в каждом ансамбле сценарному расчету предшествует ретроспективный (ист.) расчет. Для периода 1979-2016 гг. приводится наблюдаемая площадь льда, по данным NSIDC ${ }^{47}$ (черная линия).

В последнее время в литературе появляются прогнозы эволюции ледяного покрова Северного Ледовитого океана в XXI в. с детализацией по десятилетиям. $^{48}$ Такие прогнозы обычно основываются на гипотезе о периодичности собственных (т. е. не связанных с антропогенным воздействием) колебаний климатической системы и о возможности экстраполяции характеристик этих периодических колебаний в будущее. Согласно некоторым из таких прогнозов, в 2020-2030-х (в некоторых - до 2040-х) гг. ожидается более или менее интенсивное похолодание и, соответственно, рост ледяного покрова Северного Ледовитого океана. Не ставя здесь задачу подробной дискуссии с авторами подобных прогнозов, следует все же отметить, что

\footnotetext{
${ }^{46}$ Павлова Т.В., Катцов В.М., 2013: Площадь ледяного покрова Мирового океана в расчетах с помощью моделей СМІР5. Труды Главной геофизической обсерватории им. А.И. Воейкова, вып. 568, с. 7-25.

${ }^{47}$ Fetterer, F., K. Knowles, W. Meier, and M. Savoie. 2016, updated daily. Sea Ice Index, Version 2. Boulder, Colorado USA. NSIDC: National Snow and Ice Data Center. doi: http://dx.doi.org/10.7265/N5736NV7.

${ }^{48}$ См., например, Панин Г.Н., Дианский Н.А., Соломонова И.В., Гусев А.В., Выручалина Т.Ю. Оценка климатических изменений в Арктике в XXI столетии на основе комбинированного прогностического сценария. // Арктика: экология и экономика, 2-17, № 2, с. 35-52. http://arcticaac.ru/docs/2(26)_2017_Arctic/035_052.pdf; Фролов И.Е., Гудкович 3.М., Карклин В.П., Ковалев Е.Г., Смоляницкий В.М., 2007: Климатические изменения ледовых условий в Арктических морях Евразийского шельфа. Проблемы Арктики и Антарктики, № 75, с. 149-160 http://www.aari.ru/misc/publicat/paa/PAA-75/PAA75-15\%20(149-160).pdf.
} 
современная наука о климате не допускает сведѐния прогнозирования собственных колебаний климатической системы на временных масштабах от межгодового до внутривекового (междесятилетнего) к экстраполяции в будущее тех или иных «аппроксимаций» данных наблюдений. Собственная изменчивость климатической системы, действительно, предполагает наличие межгодовых и внутривековых колебаний относительно описанных в этом разделе трендов, обусловленных различными сценариями антропогенного воздействия. Однако «прогноз» пространственно-временных характеристик этих колебаний, включая конкретные временные интервалы для аномалий того или иного знака, находится за пределами возможностей современной науки о климате.

\section{3. Климатические риски для населения и экономики Российской Федерации}

\section{1 Население}

Социальное поведение человека часто очень неоднозначно, и непросто отделить воздействие изменения климата от множества других социальноэкономических и политических факторов. Степень воздействия изменения климата определяется риском, зависящим не только от связанных с климатом угроз, но также от «подверженности» людей и их уязвимости, на которые, в свою очередь, оказывает влияние большой набор социальных, экономических и культурных фракторов и процессов. Эти фракторы включают демографрические характеристики (полово-возрастную структуру населения, миграционные потоки и т. д.), доступ к технологиям и информации, характерные типы занятости и др. Наиболее негативные последствия изменения климата присущи территориям с низким качеством здравоохранения, с низким уровнем доходов населения, с высоким уровнем социальных (наркомания, алкоголизм) и демографрических проблем.

\section{Здоровье}

Согласно перспективным оценкам в XXI в. изменение климата будет оказывать воздействие на здоровье человека с весьма высокой степенью достоверности, главным образом усугубляя уже существующие проблемы. Ухудшение здоровья населения в условиях меняющегося климата будет происходить за счет ${ }^{49}$

\footnotetext{
49 Здесь и далее: МГЭИК, 2014б: Изменение климата, 2014 г.: Обобщающий доклад. Вклад Рабочих групп I, II и III в Пятый оценочный доклад Межправительственной группы экспертов по изменению климата [основная группа авторов, Р.К. Пачаури и Л.А. Мейер (ред.)]. МГЭИК, Женева, Швейцария, 163 стр. http://ipcc.ch/pdf/assessment-report/ar5/syr/SYR_AR5_FINAL_full_ru.pdf. В докладе МГЭИК (2014б) степень достоверности выражается посредством пяти качественных оценок: весьма низкая, низкая, средняя, высокая и весьма высокая.
} 
- повышенного риска травматизма, болезней и преждевременной смертности из-за более интенсивных волн тепла, ураганов, наводнений и лесных пожаров (очень высокая степень достоверности);

- повышенного риска недоедания в результате уменьшения количества продуктов питания в засушливых регионах (высокая степень достоверности);

- повышенного риска заболеваний, связанных с некачественными пищевыми продуктами и водой (очень высокая степень достоверности), и трансмиссивными заболеваниями ${ }^{50}$ (средняя степень достоверности);

- повышенного риска для психического здоровья, связанного с утратой трудоспособности и снижением производительности труда среди уязвимых групп населения (высокая степень достоверности).

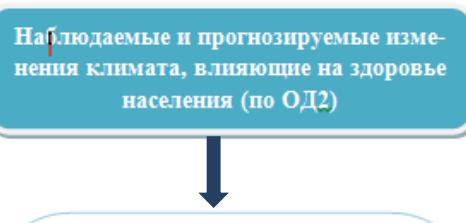

- Рост числа опасньг гидрометеорологических явлений (наводнения, пожары, ураганы)

- Возрастание частоты и интенсивно сти волн тепла

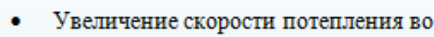
все сезоны, кроме зимнего

- Увеличение количества осадков и площадей подтопляемьг территорий. На большей части ЕЧР зимой отмечается увеличение числа суток с аномально большим количеством осадков (>10 мм), а летом — напротив, их уменьшение

- Усиление климатической составляющей опустынивания. Вероятен более частый охват засухами территории к северу от зернового пояса

- Деградация вечной мерзлоты. Согласно модельным расчетам, к середине XXI в. мерзлота протает на большей части севера Европейской части Рогсии

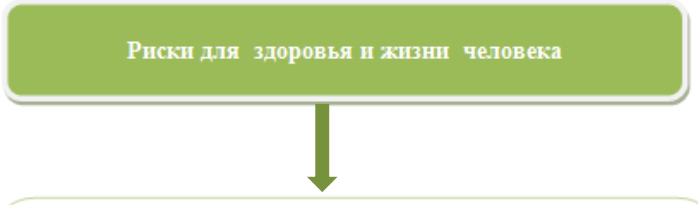

Риски прямьх воздействий

- Гибельлюдей

- Увеличение числа заболеваний, свлзанных с перегревом - системы кровообращения (инфаркт)

- цереброваскулярных заболеваний (инсульт)

- заболеваний органов дыхания (астма, гипоксия и др.)

Косвенные (экологические) риски воздействий

- Расширение ареалов переносчиков трансмиссивньх болезней чело-

века

- Рест желудочно-башегных забобеваний в местах недостаточного

водоснабжения

- Рост опасности заражения инфекционньди заботеваниям в райо-

нах деградации вечной мерзлоты

- Рост числа алтергических и простудньх заболеваний

Косвенные (социальные) риски воздействий

- Стрессы и рост психических и нервных болезней

- Рест социальньк забобелеваний (алкоголизм, наркомания, и т.д.)

Рис. 3.1 Схема путей воздействия изменения климата на здоровье человека. ОД2 здесь Росгидромет, 2014.

Можно выделить три направления, по которым изменение климата влияет на здоровье человека (рис. 3.1). Во-первых, непосредственные (прямые) воздействия - из-за экстремальных погодных явлений, в увеличении повторяемости которых изменение климата играет определенную роль. С ними связаны гибель людей, рост травматизма, повышение уровня смертности от обострения хронических заболеваний. Во-вторых, косвенные воздействия, обусловленные изменением окружающей среды и экосистем. Они

50 заразные болезни человека, возбудители которых передаются кровососущими членистоногими (насекомыми и клещами) 
сопровождаются повышением уровня смертности и заболеваемости в связи с изменением условий распространения инфекционных заболеваний комарами и клещами, с увеличением числа заболеваний, передающихся через воду, с ростом количества осадков, с увеличением поверхностного стока, с деградацией вечной мерзлоты. Третье направление - косвенные воздействия, опосредованные изменениями в социальных системах. Последствиями таких воздействий могут стать недоедание, нервные и психические расстройства, связанные как с ухудшением экономической ситуации, так и от стрессов из-за повышенной аномальности погоды и ряда других причин. ${ }^{51}$

Риски прямого воздействия зависят, прежде всего, от роста повторяемости опасных и аномальных явлений. В России число гидрометеорологических опасных явлений, нанесших значительный ущерб, за последние двадцать лет выросло вдвое. ${ }^{52}$ По данным МЧС $^{53}$ наиболее разрушительными для России являются наводнения, лесные пожары и аномальная жара. Крупные наводнения угрожают жизни людей, нарушают эпидемиологическую безопасность, являются причиной повышенного травматизма, вызывают психические заболевания. В свою очередь, сильные лесные пожары, связанные, как правило, с высокими температурами воздуха, для людей, страдающих бронхо-легочными заболеваниями (аллергией, астмой или эмфиземой), могут стать причиной летального исхода. Еще одна опасность - сочетанное воздействие аномальных температур и высокого уровня загрязнения атмосферного воздуха, вызывающее негативные изменения в центральной нервной системе, сердце, почках, печени. ${ }^{54}$

Наиболее выраженный негативный эффект влияния на человека оказывают периодически повторяющиеся волны жары. По оценке UNISDR ${ }^{55}$, аномальная жара 2010 г. в ЕЧР вошла в первую десятку самых смертоносных бедствий на Земле за последние 20 лет (седьмое место в рейтинге бедствий). По данным центра EM-Dat, в 2010 г. от жары в ЕЧР погибли 55736 человек. ${ }^{56}$ (По оценке Б. А. Ревича ${ }^{57}-54$ тыс. дополнительных случаев смерти).

Продолжительная жаркая погода вызывает увеличение числа смертей и заболеваний системы кровообращения, цереброваскулярных заболеваний, заболеваний органов дыхания и эндокринной системы, особенно у лиц старше 65 лет, а также у людей с хроническими заболеваниями сердечно-сосудистой системы и органов дыхания. Были выявлены связи между числом обращений

\footnotetext{
${ }^{51}$ Для территории Российской Федерации проблема изменения климата как фактора риска жизни и здоровью населения наиболее полно рассмотрена в (Росгидромет, 2014).

${ }^{52}$ Росгидромет, 2014.

53 Атлас природных и техногенных опасностей и рисков чрезвычайных ситуаций (Шойгу С.К., ред.), Москва, Издательство «Феория», 2011, 696 с.

${ }^{54}$ Ревич Б.А., Малеев В.В., 2011: Изменения климата и здоровье населения России: Анализ ситуации и прогнозные оценки. М.: ЛЕНАНД, 208 с.

${ }_{55}^{5}$ Бюро ООН по снижению риска стихийных бедствий.

${ }^{56}$ Poverty \& Death (2016): Disaster Mortality 1996-2015, The Centre for Research on the Epidemiology of Disasters (CRED), 22 p., http://www.unisdr.org/files/50589_creddisastermortalityallfinalpdf.pdf.

${ }^{57}$ Ревич Б.А., 2011: Волны жары, качество атмосферного воздуха и смертность населения Европейской части России летом 2010 года: результаты предварительной оценки, Экология человека, № 7, с. 3-9.
} 
за экстренной медицинской помощью, общей смертностью и смертностью от ряда причин (травмы, несчастные случаи на воде и самоубийства), с одной стороны, и температурой воздуха в летний период, с другой. Негативный эффект здоровью при воздействии температурных волн жары и холода поразному проявляется в северных и южных городах. В северных городах Мурманске, Архангельске, Магадане и Якутске - волны холода оказывают более сильное влияние на уровень смертности населения, чем волны жары. Южные города (Астрахань, Волгоград, Краснодар, Ростов-на-Дону) характеризуются наиболее выраженными потерями жизней при длительных волнах жары, основной вклад в преждевременную смертность вносят сердечнососудистые заболевания. На втором месте по величине вклада стоят новообразования, а на третьем - болезни органов дыхания. Этими тремя группами причин объясняется прирост всей естественной смертности до 85 \% и до $94 \%$ в возрастных группах от 30 до 64 лет и от 65 лет и старше, соответственно. ${ }^{58}$

Влияние изменений климата на здоровье выходит далеко за пределы очевидного прямого воздействия во время стихийных бедствий. Повышение температуры приводит к расширению ареалов переносчиков инфекционных болезней человека. Во Втором оценочном докладе Росгидромета ${ }^{59}$ детально рассмотрены причины и пути распространения целого ряда трансмиссионных инфекционных заболеваний на территории России. Современная эпидемиологическая ситуация в России характеризуется ростом числа случаев трансмиссивных заболеваний: геморрагической лихорадкой, бореллиозом, лихорадкой Лайма, лихорадкой Западного Нила. Потепление климата приводит и к расширению ареала малярии на север, а в районах, где малярия уже была свойственна ранее, увеличилась длительность сезона передачи инфекций. К 2030 г. в России ареал малярийных комаров продвинется к северу, возможно замещение их северных популяций южными. ${ }^{60}$ Произошло смещение границы распространения переносчиков клещевого энцефалита на северо-восток ЕЧР и Сибири, соответственно, и удлинился период их активности.

Продолжительный период высокой температуры воздуха, ранняя теплая весна и длительная осень являются причиной распространения определенных видов грызунов-переносчиков, что, в свою очередь, создает предпосылки для существования очагов туляремии, лептоспироза, геморрагической лихорадки с почечным синдромом, псевдотуберкулеза. Наиболее актуальна эта проблема для северных территорий России. ${ }^{61}$

Изменение климата обостряет проблему безопасности пищевых продуктов и качества питьевой воды. Тепло способствует росту бактериальной

\footnotetext{
${ }^{58}$ Ревич Б.А. и др., 2015: Волны жары в южных городах Европейской части России как фактор риска преждевременной смертности населения. Проблемы прогнозирования, № 2, с. 56-66.

${ }_{59}^{59}$ Росгидромет, 2014.

${ }^{60}$ Семенов С.М., Ясюкевич В.В., Гельвер Е.С., 2006: Выявление климатогенных изменений. М.: Издательский центр «Метеорология и гидрология», 324 с.

${ }^{61}$ Стратегия адаптации к воздействию изменения климата на здоровье населения для Архангельской области и Ненецкого автономного округа Российской Федерации (2012). Архангельск, 103 с.
} 
фрлоры в пище и воде. При температуре окружающего воздуха выше $5{ }^{\circ} \mathrm{C}$ каждое повышение средненедельной температуры на один градус обусловливает повышение уровня заболеваемости сальмонеллезами на 5-10\%. ${ }^{62}$ Повышается риск заболеваемости инфекциями с водно-пищевым путем заражения паразитарными, бактериальными и вирусными инфекциями (шистоматоз, сальмонеллез, ротавирусы, энтеровирусы и др.).

Воздействие на здоровье человека оказывают и деградация земель, и их опустынивание. К середине XXI в. ожидаются уменьшение увлажнения, особенно на засушливых землях юга ЕЧР, и увеличение повторяемости почвенных засух ${ }^{63}$. Эти процессы могут привести к недостаточности питания, возрастанию числа болезней, передающихся через недоброкачественные воду и пищевые продукты, к дополнительной смертности, особенно от сердечнососудистых и респираторных заболеваний, вызванных увеличением количества пыли, перемещаемой с пустынных и полупустынных территорий. ${ }^{64}$

Гибель близких, утрата имущества из-за прямых воздействий ведет к росту психических и нервных заболеваний. Рост температуры выше нормы также негативно влияет на нервную систему человека и даже может приводить к росту суицидов. ${ }^{65}$ Душная погода провоцирует рост алкогольных психозов. ${ }^{66}$

\section{Демографические и социальные процессы}

Помимо воздействия на здоровье человека, изменение климата оказывает серьезное влияние на социально-демографические процессы (демографрия, занятость, процессы миграции и т. д.). Изменение климата природный процесс, усугубляющий некоторые из наиболее острых социальных, социально-экономических и социально-политических проблем общества в целом. Несмотря на то, что демографические процессы в большей степени зависят от социально-экономических и политических факторов, потенциальное влияние ожидаемых изменений климата (в том числе - опосредованных) для демографической ситуации в России заслуживает специальных исследований.

Фактором риска для демографической ситуации в стране является рост опасных и аномальных явлений, которые воздействуют на динамику смертности и демографический состав населения. К группе наибольшего риска в первую очередь относятся дети младшего возраста, пожилые люди, молодые женщины, граждане, работающие на открытом воздухе. Хотя влияние этого фактора пока незначительно, оно, очевидно, будет возрастать. Даже небольшое увеличение его вклада, например, до 0,5 \%, в предстоящее

\footnotetext{
${ }^{62}$ Grjibovski A.M., Bushueva V., Boltenkov V.P. et al. 2012. Climate variations and salmonellosis in northwest Russia: a time-series analysis. Epidemiol. Infec., doi: 10:1017/S0950268812000544.

${ }^{63}$ Росгидромет, 2014.

${ }^{64}$ Ревич Б.А., Малеев В.В., 2011: Изменения климата и здоровье населения России: Анализ ситуации и прогнозные оценки. М.: ЛЕНАНД, 208 с.

${ }^{65}$ Page L.A., Hajat S. and Kovats R.S., 2007: Relationship between daily suicide counts and temperature in England and Wales. The British Journal of Psychiatry: The Journal of Mental Science, v. 191, pp. 106-112.

${ }^{66}$ Немцов А.В., Нечаев А.К., 2006: Климатические факторы заболеваемости алкогольными психозами. Климат, качество атмосферного воздуха и здоровье москвичей (Б.А. Ревич, ред.). М.: Издательское товарищество «Адамант Ъ», с. 197-213.
} 
десятилетие, в соответствии с существующими оценками стоимости среднестатистической человеческой жизни (VSL) порядка 30 млн рублей, означало бы экономический ущерб около 110 млрд рублей, или 0,3 \% ВВП. ${ }^{67}$

Еще одна демографическая проблема - урбанизация. Для России климат и его изменения не являются определяющими в этом процессе, но сам факт расселения большого количества людей в городах повышает риски для здоровья, уже непосредственно связанные с климатической системой. С ростом населения увеличивается уязвимость и подверженность городских территорий явлениям, перечисленным в табл. 3.1. Такие аномальные явления как волны жары в несколько раз повышают число дополнительных случаев смертности в городе. $^{68}$

\section{Миграция}

Изменение климата может вызвать приток мигрантов в страну. Миграции приводят к изменениям демографической структуры населения в районах расселения мигрантов: фрормируется специфическая возрастная структура, В которой доля жителей трудоспособного возраста, особенно молодежных групп, значительно выше средних показателей. Под воздействием миграций меняются социальная структура и этнический состав населения.

Несмотря на то, что достаточно сложно вычленить климатический фрактор в причинах миграции и определить политическую ответственность государств, МГЭИк ${ }^{69}$ особое внимание уделяет вопросам «климатической миграции»: «Согласно перспективным оценкам, изменение климата увеличит масштабы перемещения людей... Риск перемещения населения возрастает, когда группы населения, не имеющие ресурсов для плановой миграции, испытывают повышенную подверженность экстремальным метеорологическим явлениям, таким как паводки и засухи. Изменения в миграционных структурах могут стать ответной реакцией как на экстремальные метеорологические явления, так и на долгосрочную изменчивость и изменение климата, а миграция может также быть эффрективной стратегией адаптации».

Согласно прогнозам в мире к 2050 г. около 200 млн мигрантов будут нуждаться в защите в связи с климатическими изменениями. Особо уязвимыми являются люди, проживающие на территориях, расположенных низко над уровнем моря, и жители некоторых небольших островных государств, территория которых возвышается над уровнем моря на 3-4 м. Эти группы людей могут быть вынуждены мигрировать в результате повышения уровня моря и оседания земли. В зависимости от масштаба и типа катастрофы миграция может привести к социальному конфликту, особенно если мигрировать вынуждены представители групп, между которыми наблюдается

\footnotetext{
${ }^{67}$ Порфирьев Б.Н., 2011: Природа и экономика: риски и взаимодействия (эколого-экономические очерки). Изд. «Анкил», 356 с.

${ }^{68}$ Глобальный доклад о населенных пунктах 2011 года «Города и изменение климата: направления стратегии». http://viktorvoksanaev.narod.ru/3101_alt.pdf.

${ }^{69}$ МГЭИК, 2014б.
} 
социальная либо культурная напряженность. Кроме того, приезд мигрантов в города может рассматриваться как нежелательная конкуренция за рабочие места или ресурсы, что повышает напряженность и приводит к конфликтам с городским населением.

Для России основными климатическими факторами, влияющими на процессы миграции, являются увеличение числа и интенсивности наводнений, эрозия прибрежных районов, связанная с повышением уровня моря, деградация вечной мерзлоты. Что касается масштабов внутренних потоков мигрантов, движимых ухудшением климатических условий проживания и хозяйственной деятельности в отдельных регионах, имеющиеся экспертные оценки характеризуются большой неопределенностью и разбросом. По некоторым оценкам ${ }^{70}$ они не будут превышать порядка сотни тысяч $\left(10^{5}\right)$ человек.

Значительно выше риск климатической иммиграции в Россию из районов Центральной Азии, в частности, в связи с нарастающим дефицитом водных ресурсов. Вопрос о возможной миграции по климатическому принципу и о появлении «климатических беженцев» на территории России был поднят на пресс-конференции, посвященной глобальному потеплению и его последствиям. ${ }^{71}$ Преобладание аграрного сектора и бедность населения в Таджикистане, Узбекистане и Киргизии делают их чрезвычайно уязвимыми перед климатическими изменениями. Если население этих стран, пострадавших от климатических катаклизмов, будет поставлено в безвыходные условия существования, оно будет стремиться переехать в местности с более благоприятным климатом, и, не в последнюю очередь, - в Россию. Причем эта миграция будет носить уже не трудовой и сезонный, а постоянный характер. ${ }^{72}$

\section{Образ жизни}

Наибольшие риски изменения образа жизни под влиянием климатических изменений ожидают наиболее уязвимую часть населения России - коренные малочисленные народы, чей уклад и традиционные виды экономической деятельности (рыболовство, оленеводство, сельское хозяйство и т. п.) напрямую зависят от климатических условий. Из-за более частых оттепелей происходит образование слоя льда на грунте, который ограничивает доступ северному оленю к лишайникам, находящимся под коркой льда. Таяние вечной мерзлоты, изменения в распространении снежного покрова и наблюдаемые в последние годы более раннее таяние и более позднее образование речного льда приводят к нарушению традиционных путей миграции северных оленей

\footnotetext{
${ }^{70}$ Оценка макроклиматических последствий изменений климата на территории Российской Федерации на период до 2030 года и дальнейшую перспективу (2011), (Катцов В.М., Порфирьев Б.Н. ред.). Росгидромет. М.: Д’АРТ: Главная геофизическая обсерватория, 252 c. http://www.voeikovmgo.ru.

71 Фролов А.В., 2014: Риски и выгоды для Российской Федерации от глобального изменения климата Пресс-конференция в ТАСС, 24.11.2014. http://meteoinfo.ru/news/1-2009-10-01-09-03-06/10150-24112014.

72 Шустов А., 2010: Климат и миграция. Чем чреваты для России климатические изменения в странах Центральной Азии. http://rus.kg/news_rus/rusmir_rus/8725-ashustov-migraciya-kak-glavnyy-vyzovrossii.html.
} 
между зимними и летними пастбищами. Потепление климата и снижение ледовитости северных морей, изменения миграционных путей диких оленей и их кормовой базы, уменьшение поголовья морских животных могут выразиться в сокращении традиционных промыслов коренных малочисленных народов Арктики. В ряде стран уже предприняты адаптационные меры по переселению малых народов в специальные поселения. ${ }^{73}$ Однако это заставляет их изменить свой образ жизни, что приводит к психологическим стрессам, и впоследствии очень немногие представители коренных народов будут способны вернуться к сложной и продуманной модели кочевого оленеводства и культурным традициям.

\section{Занятость}

Согласно МГЭИК ${ }^{74}$, негативный эффрект от климатических изменений затронет в средне- и долгосрочной перспективе все отрасли экономики и будет тем сильнее, чем масштабнее эти изменения. В первую очередь, пострадают отрасли и виды экономической деятельности, где широко используются ресурсы, чувствительные к изменению климата, включая сельское и лесное хозяйства, рыболовную отрасль, сферу туризма. Как следствие, в занятости только с точки зрения рабочих мест произойдут количественные, структурные и качественные изменения: появятся новые, трансформируются или ликвидируются старые рабочие места.

Климатические изменения влияют на трудоспособность населения России, и, в частности, в результате увеличения числа случаев инфекционных заболеваний, обусловленных изменениями климата и погоды. При возникновении нетрудоспособности и возможной инвалидности причиняемый ущерб неодинаков для различных заболеваний и зависит от их частоты и степени тяжести. Наибольший ущерб трудоспособности возможен, очевидно, в результате увеличения повторяемости заболеваний клещевым энцефалитом и геморрагическими лихорадками. Это, в свою очередь, вызовет необходимость в дополнительных медицинских кадрах, прежде всего врачах-эпидемиологах.

Существует целый ряд направлений адаптационного поведения хозяйствующих субъектов в ответ на изменение климата и выявление подходов к оценке процессов, происходящих в сорере занятости. Один из них - переход к устойчивому развитию, основанному на «зеленой» промышленности. ${ }^{75}$

Предполагается создание эффективного экологического сектора экономики, который может включать бизнес в области общего и

\footnotetext{
73 Bronen, R., 2010: Forced migration of Alaskan indigenous communities due to climate change. In: Environment, Forced Migration and Social Vulnerability [Afifi, T. And J. Jдger (eds.)]. SpringerVerlagBerlinHeidelberg, Germany, p. 87-98.

${ }^{74}$ МГЭИК, 2007: IPСС, 2007: Climate Change 2007: Synthesis Report. Contribution of Working Groups I, II and III to the Fourth Assessment Report of the Intergovernmental Panel on Climate Change [Core Writing Team, Pachauri R.K and Reisinger A. (eds.)]. IPCC, Geneva, Switzerland, 104 p. http://www.ipcc.ch/pdf/assessmentreport/ar4/syr/ar4_syr_full_report.pdf.

75 Вередюк О.В., 2011: Влияние изменений климата на занятость. Вестник СПбГУ, сер. 5, вып. 4, c. $22-29$.
} 
специализированного

машиностроения,

экологического

консалтинга.

Приоритетными считаются такие секторы, как энергетика, строительство, транспорт, сельское и лесное хозяйство. Общая тенденция развития «зеленых» рабочих мест позволяет говорить о том, что парадигма «рабочие места или экология» сменяется парадигмой «рабочие места и экология».

\section{2 Национальная инфраструктура}

\subsection{1 Состояние зданий и сооружений}

Принятие климатически обусловленных решений в строительной отрасли сопряжено со значительными экономическими рисками, существенно возрастающими в условиях изменения климата.

Повышение температуры в летний сезон и увеличение повторяемости экстремально высоких температур уже в настоящее время приводят к нарушению соответствующих санитарно-гигиенических показателей в домах старой постройки, а в перспективе - при отсутствии адаптации - проблема борьбы с перегревом зданий значительно обострится. Ожидаемый рост летних температурных экстремумов, который влечет перегрев зданий, значительно увеличивает риск системных аварий, возникающих при одновременном резком увеличении энергопотребления, снижении генерации энергии и больших потерях на линиях электропередач.

Обеспечение долговечности ограждающих конструкций зданий ${ }^{76}$ является одной из современных проблем, связанных с прямым воздействием климатических изменений, а также с принятием комплекса регламентирующих мер, имеющих своей целью смягчение изменений климата.

В последние десятилетия отмечается тенденция к ускоренному старению и уменьшению долговечности ограждающих конструкций зданий и сооружений, определяемой сроком их службы без потери эксплуатационных качеств. Наблюдаемое усиление разрушающего действия температурно-влажностных деформаций связано с особенностями происходящих климатических изменений (рост количества жидких и смешанных осадков в зимний сезон, увеличение числа циклов замораживания и оттаивания, повышенное увлажнение стен зданий с последующим охлаждением), которые не были учтены при выборе материалов ограждающих конструкций надлежащей стойкости. По этой причине находятся в аварийном состоянии многие здания, построенные в 1960-х годах (например, в Якутске цокольная часть кирпичных зданий полностью разрушена из-за конденсации влаги в стенах). Негативное влияние роста числа циклов замораживания и оттаивания наиболее выражено на территории ЕЧР. В сочетании с увеличением количества жидких осадков в холодное время года это приводит к ускоренному старению зданий и сооружений. Согласно

\footnotetext{
76 Ограждающие конструкции здания - строительные конструкции, отделяющие внутреннее
} пространство здания от внешней среды. 
модельным оценкам, в ближайшие десятилетия эта тенденция сохранится и потребует серьезного увеличения эксплуатационных расходов.

Еще одна причина уменьшения долговечности существующих зданий в значительной мере связана с принятием в 1990-х гг. регламентирующих мер по смягчению изменений климата и повышению энергоэффективности зданий. Выполнение соответствующих требований привело к использованию многослойных конструкций и широкому применению теплоизоляционных материалов, долговечность которых - при условии их эксплуатации в разнообразных климатических условиях России - не была должным образом изучена. В результате десятки зданий оказались аварийными после 7-9 лет эксплуатации вследствие разрушения фрасадных систем. Особенно острая ситуация сложилась при строительстве капитальных объектов в северной строительно-климатической зоне. ${ }^{77}$

Важным аспектом обеспечения надежности, безопасности и долговечности сооружений является учет атмосферных нагрузок. Имеющиеся данные наблюдений не дают оснований говорить о заметном увеличении ветровых нагрузок. Ряды наблюдений за скоростью ветра на метеорологических станциях (однородность которых вызывает определенные сомнения) обнаруживают даже слабо выраженную отрицательную тенденцию. Однако при сохранении или слабом изменении средних значений скоростей ветра в некоторых регионах возможна трансформация их вероятностных распределений за счет увеличения вклада штормовых скоростей. В этом отношении требуются дополнительные региональные исследования. В связи с ростом экстремально высоких температур и увеличением количества осадков можно ожидать также усиления эффектов, обусловленных совместным воздействием ветровых нагрузок, температурных деформаций и коррозионного разрушения.

В условиях изменений климата, когда наблюдается увеличение интенсивности зимних осадков, особое значение для объектов строительства приобретают кратковременные снеговые нагрузки, возникающие при сильных снегопадах. Ожидаемые изменения, характеризующиеся усилением этой тенденции, являются дополнительным фактором риска для зданий и сооружений с легкими покрытиями.

Важнейшая составляющая безопасности зданий и сооружений обусловлена состоянием грунтов. Увеличение меженных расходов и уровня воды в реках в условиях уменьшения промерзания почвогрунтов способствует повышению уровня грунтовых вод и подтоплению равнинных территорий. Эти процессы приводят к деформации фундаментов зданий и сооружений и создают дополнительные риски их разрушения. Однако наиболее высокие климатические риски возникают в зоне многолетнемерзлых грунтов.

\footnotetext{
77 Термин «строительно-климатическая зона» восходит к ГОСТам по климатическому районированию СССР для технических целей.
} 


\subsection{2 Транспортная инфраструктура}

\section{Наземная транспортная инфраструктура}

Климат и его изменения оказывают значительное воздействие на состояние наземной транспортной инфраструктуры (автомобильные и железные дороги, мосты, тоннели, портовая инфраструктура, взлетнопосадочные полосы и пр.), а также обеспечение организации движения и эфффективность фрункционирования транспорта (расходы на содержание объектов, безопасность движения, скорость транспортных потоков и пр.). Наблюдаемые и ожидаемые климатические изменения термического режима и режима увлажнения в целом оказывают негативное воздействие на состояние и функционирование наземной транспортной инфраструктуры. ${ }^{78}$ Основные виды неблагоприятных воздействий, обусловленных происходящими климатическими изменениями, проявляются уже в настоящее время. К середине XXI в. ожидается усиление отмечаемых тенденций.

Повышение температуры воздуха в холодный период года сопровождается частыми перепадами температуры, которые способствуют ускоренному разрушению покрытия автомобильных дорог. Особенно интенсивно процесс разрушения материалов происходит при частых переходах температуры воздуха через $0{ }^{\circ} \mathrm{C}$. Увеличение количества жидких осадков, сопровождающих оттепели, является дополнительным фрактором, усиливающим процесс разрушения. Влияние этих эффектов наглядно проявляется на состоянии автодорог уже в настоящее время. При этом увеличиваются расходы на так называемый «ямочный» ремонт.

Рост температуры воздуха в летний сезон приведет к большему числу дней с экстремально высокими температурами воздуха, что отрицательно скажется на состоянии автомобильных дорог. В таких условиях происходит размягчение асфальтового покрытия и быстрое ухудшение эксплуатационных качеств автодорог, увеличивающее риск аварий. Это является особенно существенным для дорог местного значения, не рассчитанных на большую нагрузку, покрытие которых обладает сравнительно низкой температурой плавления. При экстремально высоких температурах воздуха происходит значительный перегрев рельсов и последующая деформация железнодорожных путей, приводящая к уменьшению скорости передвижения и увеличивающая риск схода с рельсов подвижного состава. Особую опасность представляют экстремальные температуры для службы сигнализации и связи

\footnotetext{
${ }^{78}$ Chapman, L., 2007. Climate Change and Transport: A Review. Journal of Transport Geography, v. 15, p. 354-367; Koetse M.J., Rietveld P., 2009. The impact of climate change and weather on transport: An overview of empirical findings. Transportation Research, Part D, v. 14, p. 205-221; Jaroszweski D., Chapman L., Petts J., 2010. Assessing the potential impact of climate change on transportation: The need for an interdisciplinary approach, Journal of Transport Geography, v. 18, p. 331-335; Самодурова Т.В., 2008. Физикостатистические модели для прогноза образования зимней скользкости на дорожных покрытиях, Научный вестник Воронежсккого государственного архитектурно-строительного ун-та, № 1, с. 126-129; Хлебникова Е.И., Салль И.А., 2012. Климатические воздействия на инфраструктуру прибрежных территорий России в первой половине 21-го века. Труды Главной геофизической обсерватории им. А.И. Воейкова, вып. 567, с. 83-126.
} 
на железных дорогах, так как при сильной жаре могут выходить из строя устройства автоблокировки, обеспечивающие надежность работы семафоров. ${ }^{79}$

Состояние и фрункционирование транспортной инфраструктуры в большой степени зависит от количества осадков и режима их выпадения. Рост количества осадков в зимний сезон и увеличение их суточных максимумов повлекут за собой необходимость принятия дополнительных мер по организации движения и обеспечению безопасности на дорогах и приведут к увеличению эксплуатационных расходов на зимнее содержание дорог ${ }^{80}$. Более частые переходы через температурную нулевую отметку, продолжительные снегопады, выпадение жидких осадков в холодное время года также негативно отразятся на безопасности дорожного движения и потребуют принятия специальных мер по уменьшению скользкости на дорогах. ${ }^{81}$ Сильные снегопады и метели чрезвычайно затрудняют функционирование железнодорожных станций и узлов, так как постоянная занятость станционных путей подвижным составом осложняет использование снегоуборочной техники.

К середине XXI в. на территории России преимущественно ожидается увеличение суммы осадков в теплый сезон. Важным фрактором является сопутствующий этому увеличению рост суточной интенсивности осадков. Сильные дожди негативно сказываются на скорости транспортных потоков и безопасности дорожного движения. Несоответствие существующих дренажных систем ожидаемому увеличению интенсивности осадков может повлечь разрушение грунтовых зон автомобильных и железных дорог и других объектов. Рост количества и интенсивности осадков в теплое время года увеличит риски возникновения опасных последствий, связанных с потерей устойчивости склонов - оползней, лавин. Такие риски особенно возрастают в случаях, когда сухие периоды чередуются с периодами интенсивных ливней. Неоднократные случаи разрушения новой автодороги, построенной в Приморье к саммиту АТЭС в 2012 г., привели к большому материальному ущербу и наглядно продемонстрировали важность и экономическую целесообразность учета климатических факторов на этапе проектирования и строительства инженерных сооружений.

Рост интенсивности ливневых осадков представляет особую опасность, так как при этом повышается вероятность речных ливневых наводнений, которые могут вызвать затопление и разрушение всей прибрежной инфраструктуры. В горных районах в случае выпадения сильных дождей большой интенсивности наблюдается процесс забивания почвенных пор мелкодисперсными частицами почвы, резко увеличивается коэффицциент

\footnotetext{
79 Зябриков В.А., Кобышева Н.В., Циркунов В.С., 2000. Климат и железнодорожный транспорт. Метеоагентство Росгидромета, 187 с.

${ }^{80}$ Самодурова Т.В., 2008. Физико-статистические модели для прогноза образования зимней скользкости на дорожных покрытиях, Научный вестник Воронежского государственного архитектурностроительного ун-та, № 1, с. 126-129.

81 Псаломщикова Л.М., Салль И.А., Стадник В.В., Трофимова О.В., 2008. Использование метеорологической информации в целях содержания автомобильных дорог в зимний период. Tpyдbl Главной геофизической обсерватории им. А.И. Воейкова, вып.557, с. 85-101.
} 
поверхностного стока, и паводки принимают характер катастрофических наводнений, особенно при охвате большими осадками значительной площади речного бассейна. ${ }^{82}$ При этом от момента выпадения осадков до начала интенсивного подъема уровня воды в реке может проходить менее 1-3 ч. При отсутствии превентивных адаптационных мероприятий такие наводнения могут иметь тяжелые последствия. Известный пример - Крымск, июль 2012 г.

\section{Трубопроводный транспорт}

Особое значение имеют последствия изменений климата для состояния трубопроводного транспорта. ${ }^{83}$ В зоне сезонного промерзания грунтов аварийные разрушения трубопроводов часто происходят в районах со сложными гидрогеологическими условиями, для которых характерен высокий риск возникновения оползневых и селевых процессов. ${ }^{84}$ Важнейшим фрактором, определяющим степень развития этих процессов, является количество и интенсивность осадков. В таких условиях ожидаемое увеличение сезонных сумм осадков и особенно их интенсивности в теплый сезон являются серьезным дополнительным фрактором риска, который необходимо принимать во внимание при эксплуатации существующих и проектировании новых трубопроводов.

В России проложено около 50 тыс. км нефтепроводов и около 150 тыс. км газопроводов. Они пересекают многие реки, протекающие по территории России. Через крупные и средние реки построено около 2000 переходов нефтепроводов. В каждом из таких коридоров располагается до 25 ниток трубопроводов.

Прокладка трубопроводов через водную преграду - весьма дорогостоящее и технически трудное мероприятие. Так, стоимость прокладки трубы на переходе через реку шириной 1-2 км составляет 120-150 млн руб. Часто соизмеримыми оказываются и затраты на капитальный и текущие ремонты перехода за период его эксплуатации. Расчетный период эксплуатации трубопровода на подводном переходе зависит от метода его сооружения. При траншейном методе прокладки он составляет 25-30 лет, при методе наклонно-направленного бурения - 50 лет. Нередки случаи, когда ремонт или переукладка трубопровода на переходе выполняется ранее расчетного срока эксплуатации. Одной из вероятных причин досрочного наступления срока окончания эксплуатации трубопровода может быть

\footnotetext{
82 Борщ С.В., Асарин А.Е., Болгов М.В., Полунин А.Я., 2012: Наводнения. В кн. «Методы оценки последствий изменений климата для физических и биологических систем» (под ред. С.М.Семенова). Росгидромет, с. 87-125.

${ }^{83}$ Власова Л.В., 2009: Природные факторы при аварийности газопроводов. Геоэкология. Инженерная геология, гидрогеология, геокриология, №3, с. 264-270; Власова Л.В., Ракитина Г.С., 2010. Результаты статистической обработки информации в целях идентификации природных рисков для газотранспортной системы России и роль климатической информации при управлении рисками в условиях глобального изменения климата. Труды ВНИИГМИ-МЦД. Вып.174.

${ }^{84}$ Казаков Н.А., Генсиоровский Ю.В., 2008. Экзогенные геодинамические и русловые процессы в низкогорье о. Сахалин как факторы риска для нефтегазопроводов «Сахалин-2». Геоэкология. Инженерная геология. Гидрогеология. Геокриология. № 6, с. 483-496.
} 
наступление климатического периода, и, в частности, уже наступившего три десятилетия назад современного периода потепления климата. Дело в том, что ареной строительства и эксплуатации переходов через реки магистральных трубопроводов являются поймы и русла водотоков, представляющие собой непрерывно меняющуюся топографическую основу, что проявляется в деформациях дна и берега русла и поверхности поймы. На весь расчетный период эксплуатации перехода трубопровод должен находиться вне пределов возможного размыва русла и берегов реки, т. е. вне профиля предельного размыва русла. Прогноз положения профиля предельного размыва русла определяется по среднестатистическим параметрам потока и русла - по расходу воды и скорости деформации ложа водотока.

Поскольку основное количество трубопроводов в стране было построено в 1950-1970-х гг., т. е. до наступления современного климатического периода, и не было рассчитано на возможность потепления климата, увеличения расходов воды и интенсификации русловых деформаций, то уменьшение расчетного срока эксплуатации переходов оказалось в определенной мере неожиданным. Появившаяся на некоторых переходах более ранняя по сравнению с проектной трансформация расчетного предельного профриля размыва русла привела к возникновению аварийных ситуаций, необходимости ранних ремонтов и создала предпосылки для экологических катастроф при разрыве трубопроводов и последующих разливах нефти и выбросах газа.

Практика эксплуатации переходов магистральных трубопроводов через реки позволяет в первом приближении утверждать, что климатическое увеличение среднегодовых, летне-осенних и зимних расходов воды усиливает вероятность досрочного размыва магистральных трубопроводов на подводных переходах через реки по двум причинам:

- из-за увеличения времени воздействия повышенных расходов воды на берега и русло реки, т. е. из-за увеличения времени размыва русла - вместо 3-4 месяцев в половодье, когда обычно деформации максимальны, время размыва удлиняется до 10-12 месяцев, включающих период летне-осенней и зимней межени;

- из-за более раннего наступления фрактического срока критического размыва трубопроводов по сравнению с проектным расчетным сроком, при определении которого климатическая составляющая не учитывалась.

Места наиболее проблемных подводных переходов трубопроводов расположены в следующих федеральных округах:

- Приволжский федеральный округ - области: Нижегородская, Оренбургская, Пермская, Самарская, Саратовская, Ульяновская; республики: Башкортостан, Марий Эл, Мордовия, Татарстан, Удмуртская, Чувашская; реки: Верхняя и Средняя Волга, средние и малые реки бассейна Волги;

- Южный федеральный округ - области: Астраханская, Волгоградская, Ростовская; Краснодарский край; реки: Нижняя Волга, Кубань и ее притоки, Дон и его притоки; 
- Северо-Кавказский фредеральный округ - Ставропольский край; республики Северного Кавказа; реки Северного Кавказа;

- Уральский федеральный округ - область Тюменская; реки: Нижняя Обь и ее притоки, Нижний Иртыш и его притоки;

- Сибирский федеральный округ - области: Новосибирская, Омская, Томская, Иркутская; Красноярский край; реки: Средний Иртыш и его притоки, Средняя Обь и ее притоки, Верхний Енисей и его притоки;

- Дальневосточный федеральный округ - Хабаровский край, Сахалинская область; реки: Нижний Амур, реки о. Сахалин.

Речное судоходство и ледовые трассы

Возможное при потеплении климата сокращение периода ледостава на реках и водоемах и уменьшение максимальной толщины льда будут способствовать заметному продлению периода навигации. Ожидаемые при изменении климата увеличение годового и меженного стока и изменение продолжительности и сроков навигации практически для всех крупных рек России потенциально могут благоприятствовать развитию речного судоходства и увеличению объема грузоперевозок по рекам и водоемам.

На многих судоходных реках России вследствие влияния изменений климата на сток рек наблюдаются существенные изменения в русловых процессах, осложняющих судоходство. В перспективе тенденции изменения русловых процессов будут нарастать. Это негативно отразится на судоходстве и потребует увеличения работ по дноуглублению и выправлению русел рек. Вместе с тем, вероятные при потеплении климата увеличение частоты и интенсивности опасных метеорологических и гидрологических явлений (шквалы, смерчи, ливни, резкие паводки и т. п.) могут сказаться на безопасности судоходства.

В основе концепции оценки влияния изменения климата на речное судоходство лежат комплексный мониторинг вышеуказанных фракторов, непосредственно влияющих на судоходство, сопоставление их с современными изменениями гидрометеорологических параметров $и$ экстраполяция $\mathrm{B}$ перспективу с учетом сценариев изменения климата будущего.

Прогнозируется сокращение периода ледостава на реках и водоемах в Сибири и в бассейне р. Камы до 15-27 суток и уменьшение максимальной толщины льда на 20-40 \%, а также значительные изменения в процессах замерзания и вскрытия рек и водоемов. Это, с одной стороны, способствует заметному продлению времени речного судоходства, а, с другой, сокращает период доставки грузов в труднодоступные районы по зимним автомобильным трассам, проложенным по замерзшим руслам больших рек. Такие изменения в режиме озер имеют как положительные, так и негативные последствия для жизнедеятельности многих субъектов Российской Федерации - Сибирского и Дальневосточного федеральных округов, особенно для Республики ЯкутияСаха и Магаданской области, где основной объем грузов доставляется по рекам: летом - судами, а зимой - автомобильным транспортом. 
Отдельно следует отметить реки, зарегулированные гидроузлами ГЭС и водохранилищами. Оценка влияния изменений климата на речное судоходство на этих реках затрудняется тем, что в современных условиях ГЭС и водохранилища являются объектами комплексных водохозяйственных систем, использующих речной сток для достижения одновременно или последовательно нескольких целей, в том числе и судоходства. Увеличение притока воды в меженные периоды и выравнивание внутригодового распределения стока благоприятны для судоходства, но требуют пересмотра режима работы водохранилищ и их каскадов для создания оптимальных условий регулирования стока с учетом запросов всех водопользователей и при минимизации возможных неблагоприятных экологических и социальных последствий. Оптимальное управление водными ресурсами водохранилищ позволит избежать отрицательных последствий для судоходства, которые имели место, например, на Чебоксарском и Куйбышевском водохранилищах, а также в низовьях Волги летом и осенью 2010 г., когда снизившийся в результате маловодья уровень воды сильно затруднил речное судоходство. В этом отношении для судоходства справедливо все то, что было сказано выше относительно гидроэнергетики - необходимы развитие гидрометеорологического мониторинга на реках и водосборах водохранилищ и совершенствование методов краткосрочных и долгосрочных прогнозов притока к водохранилищам.

A)
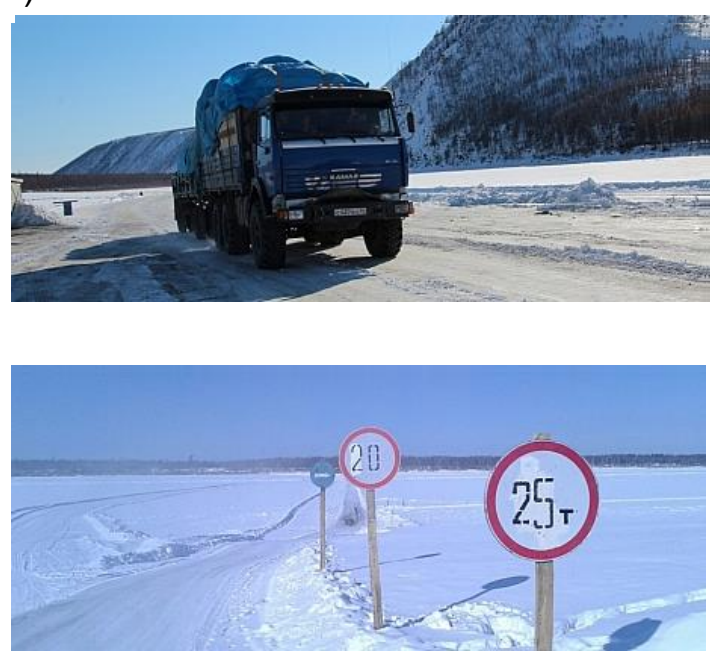

Б)
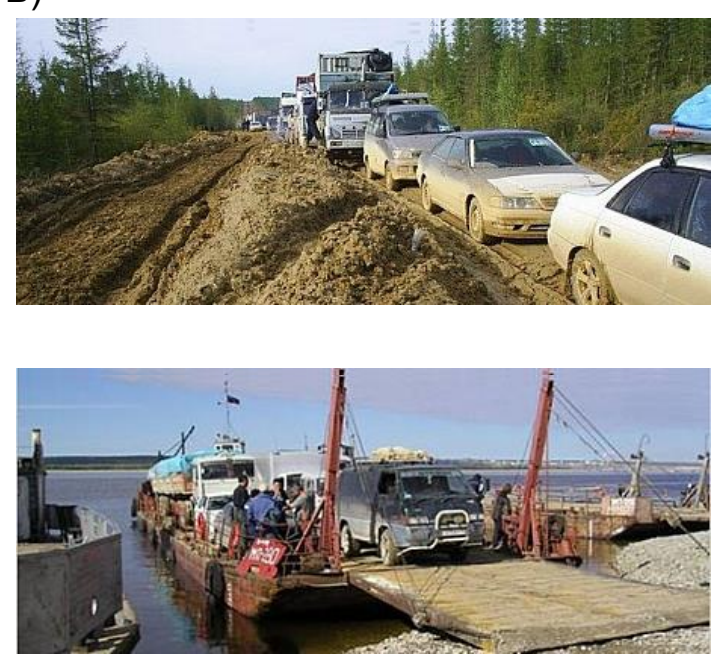

Рис. 3.2 Различие транспортных условий в зимний (А) и летний (Б) периоды в районах с использованием зимних дорог и ледовых/паромных переправ. На фотографиях показаны зимняя дорога и переправы через р. Лену в районе Якутска, а также фрагмент трассы «Лена» в летний период.

Особую группу транспортных сооружений составляют зимние дороги (зимники) и ледовые переправы, период эксплуатации которых сокращается с развитием климатического потепления. Принято считать, что такие сооружения обслуживают, главным образом, небольшие удаленные арктические поселки, однако в действительности это не так. Якутск, интенсивно развивающийся 
город с населением более 300 тысяч человек, расположен на левом берегу реки Лены и из-за отсутствия постоянно действующего моста несколько месяцев в году изолирован от железнодорожных узлов в Нерюнгри и Алдане. Большую часть года снабжение города осуществляется, помимо крайне дорогостоящего авиационного, автомобильным транспортом с использованием ледовой или паромной переправы (рис. 3.2). Таким образом, проблема зимников и ледовых переправ напрямую затрагивает устойчивое развитие городов Арктики.

\subsection{3 Энергетическая инфраструктура}

Энергетическая отрасль экономики характеризуется исключительным разнообразием типов инфраструктуры, включая установки по добыче и транспортировке топлива, электростанции различных типов, электросетевое хозяйство. Наблюдаемые и ожидаемые в будущем климатические изменения служат источником возникновения рисков практически для всех указанных объектов.

При анализе погодно-климатических рисков для энергетической инфраструктуры необходимо выявлять риски как экстремальных явлений, так и медленных климатических изменений. По своей природе эти изменения значительно отличаются от экстремальных климатических явлений и имеют долгосрочные и широкомасштабные последствия. При этом медленные изменения оказывают ощутимое влияние на частоту, интенсивность, пространственное распределение и длительность экстремальных явлений. Важным является и тот факт, что в долгосрочной перспективе постепенные изменения могут затронуть значительно большие территории, чем экстремальные явления.

\section{Добыча ископаемого топлива}

Наиболее значимыми для устойчивого функционирования нефтегазового комплекса России являются экстремальные погодные явления, воздействующие на температурно-ветровой режим, а также медленные климатические изменения, приводящие к таянию многолетнемерзлых пород. Несмотря на рост средних годовых и месячных температур воздуха и уменьшение средних скоростей ветра в большинстве районов добычи углеводородов, наблюдается рост числа аварий в этом секторе экономики в последние 10 лет, при этом примерно $60 \%$ аварий связано с метеорологическими фракторами. Это объясняется тем, что в прибрежной зоне арктических морей возрастает повторяемость штормовых скоростей ветра, что особенно опасно для буровых установок, расположенных на шельфе. Увеличение повторяемости штормовых нагонов приводит также к усилению береговой эрозии, особенно на побережье Берингова и Карского морей, что угрожает портовым причалам. Вследствие роста температуры происходит несвоевременное таяние зимников (включая движение по рекам), часто являющихся основными дорогами в районах нефте- и газодобычи на севере и 
северо-востоке Российской Федерации, а, следовательно, значительно сокращается время возможного перемещения людей и грузов, что создает дополнительные риски для снабжения нефтегазового комплекса. Увеличение температуры в летний период провоцирует риски уменьшения добычи газа, так как превышение температурой отметки в $15^{\circ} \mathrm{C}$ приводит к падению мощности компрессорных станций и к уменьшению добычи топлива. ${ }^{85}$

Последствия таяния многолетней мерзлоты носят комплексный характер и обуславливают транспортные риски (разрушение автомобильных и железных дорог, трубопроводов, ухудшение состояния взлетно-посадочных полос), а также риски снижения производительности нефтяных скважин, поскольку при таянии мерзлоты скважины деформируются, и их последующее восстановление приводит к потерям добычи нефти на 10-20 \%.

Погодно-климатические риски, характерные для добычи и транспортировки других видов ископаемого топлива - каменного и бурого угля обусловлены изменением режима увлажнения во многих регионах России, где производится добыча этого топлива, например, в Кузнецком и Канско-Ачинском бассейнах. Увеличение сумм осадков в этих районах приводит к дополнительному намоканию угля на открытых топливных складах, что на 1-3 \% уменьшает тепловую экономичность энергоустановок, использующих это топливо. В масштабах страны это вызывает дополнительный расход в размере 0,5-1 млн тонн условного топлива в год.

\section{Производство электроэнергии}

На территории страны производство электроэнергии осуществляется в рамках комплекса ЕЭС России, куда входит около 700 электростанций мощностью свыше 5 МВт. На начало 2016 г. общая установленная мощность электростанций ЕЭС России составила 235,3 ГВт.

A)

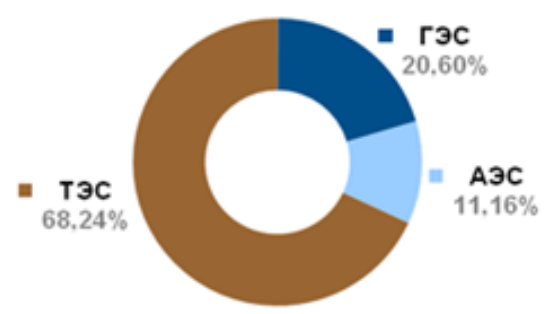

Б)

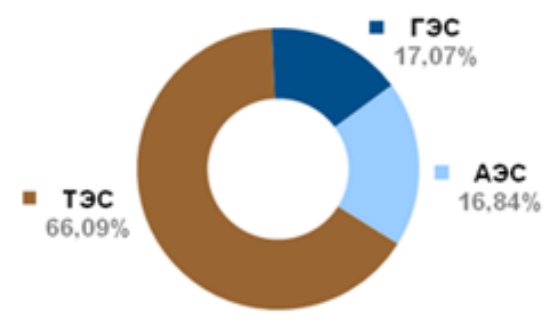

Рис. 3.3 Структура установленной мощности (А) и выработки электроэнергии (Б) в ЕЭС России (на 01.01.2016 г.).

Ежегодно все электростанции России вырабатывают около одного триллиона кВт॰ч электроэнергии. В 2015 г. станции ЕЭС России выработали

\footnotetext{
${ }^{85}$ Akentyeva E.M., 2010: Requirements of Oil and Gas Complex for Climate Data, Information, Products and Services in High Latitudes. In: Management of Weather and Climate Risk in the Energy Industry (Troccoli A., ed.), Springer Academic Publisher, p. 165-171.
} 
1 026,88 млрд кВт॰ч (на 0,2 \% больше, чем в 2014 г.). На рис. 3.3 представлена структура установленной мощности и выработки электроэнергии ЕЭС Российской Федерации. Лидирующее положение теплоэлектростанций является исторически сложившейся закономерностью развития российской энергетики.

\section{ТЭС и АЭС}

Погодно-климатические риски для ТЭС и АЭС обусловлены воздействием экстремальных метеорологических явлений, таких как смерчи, высокие скорости ветра и температуры воздуха, экстремальные осадки и снегопады. При этом неблагоприятные и опасные погодные явления угрожают не только безопасному функционированию электростанций, но также могут значительно уменьшить эффективность энергоблоков, так как при аномальных температурных условиях требуется снижение их мощности или полная остановка. Так, например, возрастание на $6{ }^{\circ} \mathrm{C}$ наружной температуры в среднем вызывает уменьшение на 0,5 \% эфрфективности и падение на 3-4 \% выходной мощности газовой турбины.

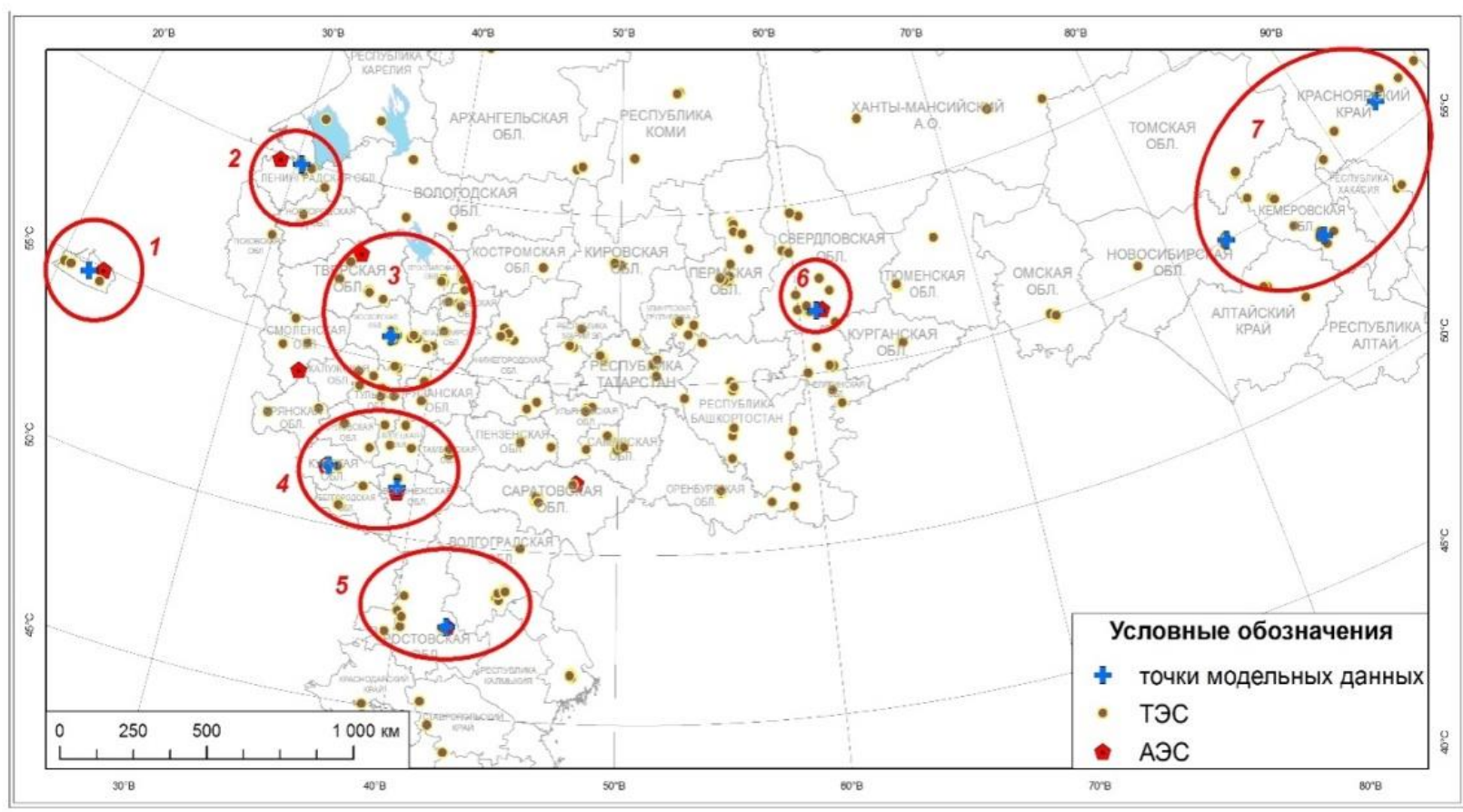

Рис. 3.4 Расположение районов с высокой концентрацией АЭС и ТЭС в ЕЧР и на юге АЧР: 1 - Калининградская область; 2 - Санкт-Петербург и Ленинградская область; 3 - Москва и Московская область; 4 - Центрально-Черноземный район; 5 - Ростовская область; 6 - Свердловская область; 7 - Юг Сибири.

Для нормальной эксплуатации ТЭС и АЭС наиболее важно бесперебойное функционирование конечного поглотителя тепла, в качестве которого выступают атмосфера и водоем (пруд-охладитель). Критические воздействия окружающей среды, которые могут вызвать опасные состояния систем охлаждения агрегатов электростанций, связаны с возникновением 
длительных периодов жаркой погоды (волн тепла) при малом количестве осадков. ${ }^{86}$ Анализ наблюдаемых трендов и оценок ожидаемых к середине XXI в. изменений этих характеристик, проведенный в семи регионах России с наибольшей плотностью расположения атомных и тепловых электростанций (рис. 3.4), показывает, что наибольшие погодно-климатические риски для нормального функционирования указанного типа электростанций характерны для Центрально-Черноземного района (прежде всего, района размещения Нововоронежской АЭС) и Ростовской области, где наблюдались наиболее значимые тренды всех рассматриваемых показателей.

Эксплуатация ТЭС (прежде всего ТЭС, использующих уголь, мазут и низкокалорийное топливо) сопряжена со значительным риском изменения режима регионального загрязнения атмосферы. Этот фактор в условиях климатических изменений может существенно повлиять на жизнедеятельность общества.

$\underline{\Gamma Э С}$

Климатические изменения влияют на следующие характеристики функционирования и развития гидроэнергосистем:

- изменение потенциальных гидроэнергоресурсов страны;

- изменение фактической выработки энергии на существующих ГЭС;

- изменение потребной гарантированной выработки электроэнергии, связанной с климатическими изменениями (например, вследствие снижения энергозатрат на отопление зданий или уменьшения энергопотребления орошаемого земледелия при снижении оросительных норм).

Изменение выработки гидроэлектроэнергии на конкретных ГЭС в отдельные годы при неизменности технических условий функционирования их оборудования и стабильности экономической ситуации в значительной степени зависит от притока воды к створу гидроузла. При снижении притока следует ожидать отрицательного влияния на производство гидроэлектроэнергии, а при увеличении притока, если он правильно регулируется во времени, положительного.

Объекты гидроэнергетики проектируются и строятся с большим запасом надежности. Гидрологическая безопасность ГЭС основана на принятии проектных значений максимальных уровней воды в водохранилищах у плотин, а также соответствующих максимальных расходов воды в нижних бьефах гидроузлов, которые обеспечивают сохранность гидротехнических сооружений при пропуске половодий и паводков с вероятностью не менее 0,9999.

Наибольшие погодно-климатические риски в гидроэнергетике связаны с аномально большими или аномально малыми объемами воды, поступающими на водосбор ГЭС с осадками или в период снеготаяния. В связи с наблюдающимся и ожидаемым в будущем климатообусловленным

\footnotetext{
${ }^{86}$ Кобышева Н.В., Акентьева Е.М., Галюк Л.П., 2015: Климатические риски и адаптация к изменениям и изменчивости климата в технической сфере. СПб: «Издательство Кириллица», 214 с.
} 
увеличением максимальных расходов и уровней наводнений различного генезиса, важнейшей проблемой является обеспечение безопасности гидротехнических сооружений в связи с тем, что пропускная способность водосбросов действующих гидроузлов может оказаться недостаточной, и при прохождении экстремальных расходов воды повышается риск повреждения и разрушения плотин. По данным Международной комиссии по большим плотинам, основная причина их прорыва заключается именно в недостаточной пропускной способности водосбросов, из-за чего происходит более $30 \%$ общего числа аварий. ${ }^{87}$

Для проектирования и эксплуатации ГЭС очень важна информация о режиме осадков и запасах воды в снежном покрове на водосборе водохранилища, от которых зависит объем притока воды в водохранилище, а также уровни в верхнем и нижнем бьефах. Так, изменение в месячных суммах осадков на $1 \%$ в среднем вызывает 1\%-е изменение в выработке электроэнергии на ГЭС. ${ }^{88}$

Если объем притока воды оказывается значительно большим нормы, то могут потребоваться холостые сбросы воды, представляющие опасность для населенных пунктов, расположенных ниже по течению. Если же объем притока будет меньше нормы, то водохранилище может оказаться незаполненным до нормального подпорного уровня. Возникающую при этом недовыработку ГЭС приходится в этих случаях компенсировать энергией от других источников.

В ближайшие десятилетия нет оснований ожидать каких-либо значительных изменений водных ресурсов основных рек страны в результате антропогенного потепления климата. ${ }^{89}$ Наиболее вероятно незначительное (в пределах 5 \%) увеличение годового стока. В первой трети текущего столетия можно ожидать незначительного (до 5 \%) повышения годового стока в бассейне Волги. Такие изменения находятся в пределах естественной изменчивости годового стока и не могут оказать существенного влияния на суммарную годовую выработку электроэнергии на ГЭС страны.

Вместе с тем, происходят существенные климатообусловленные изменения во внутригодовом распределении стока рек страны. ${ }^{90}$ Они выражаются в значительном увеличении меженного стока, главным образом зимнего. Так, в ЕЧР, как правило, водность рек зимой увеличивается на 50-120\%. Отмечаются значимые положительные тренды зимнего стока и существенное увеличение его изменчивости. Такое внутригодовое распределение стока благоприятно для большинства регионов России, так как в зимнее время возрастают бытовые нагрузки на энергетические системы страны.

\footnotetext{
${ }^{87}$ Малик Л.К. Факторы риска повреждения гидротехнических сооружений. Проблемы безопасности. М., Наука, 2005, 354 с.

88 Энциклопедия климатических ресурсов Российской Федерации (Н.В. Кобышева, ред.). СПб, Гидрометеоиздат, 2005, 319 с.

${ }^{89}$ Росгидромет, 2014.

90 Росгидромет, 2014.
} 
Вместе с тем, увеличение притока воды в меженные периоды может потребовать пересмотра правил использования водных ресурсов водохранилищ и каскадов для создания оптимальных условий регулирования стока с учетом запросов всех водопользователей и при минимизации возможных негативных экологических и социальных последствий. К таким последствиям относятся: возможное затопление и подтопление населенных пунктов, увеличение длины полыньи в нижних бьефах, что вызовет ухудшение климатических условий в береговой зоне (увеличение влажности воздуха, повторяемости туманов, ухудшение видимости и т. п.); возможно также повышенное образование шуги и развитие зажорных явлений на участках рек ниже полыньи, появление трещин и разводов на льду водохранилищ.

В последние годы в зоне наибольших погодно-климатических рисков, значимых для гидротехнических сооружений, находятся бассейн р. Амура и расположенные там Зейская и Бурейская ГЭС. Учитывая наблюдаемое уже сейчас возрастание межгодовой изменчивости метеорологических и гидрологических параметров в этом регионе, можно предположить, что величина слоя стока редкой обеспеченности (1\% и 0,01\%), наиболее важная для гидротехнических расчетов, в середине XXI в. возрастет еще более значительно. ${ }^{91}$

Для гидроэнергетики особенно значимы не только прямые, но и косвенные погодно-климатические риски, возникающие вследствие возможного изменения структуры и характера водопотребления и водопользования в связи с климатическими изменениями. При этом возможны усиления конкурентных столкновений в борьбе за воду различных отраслей хозяйства и отдельных потребителей. Так, при повышении температуры воздуха увеличится расход воды на водоснабжение, при увеличении стока уменьшатся его затраты на ирригацию. При уменьшении стока могут возникнуть проблемы с удовлетворением запросов водного хозяйства, что отразится на использовании ГЭС в энергосистемах. Неодинаковые изменения стока на реках потребуют оптимизации совместной работы ГЭС, в том числе многоступенчатых каскадов ГЭС в энерго- и водохозяйственных системах.

\section{Электросетевое хозяйство}

На начало 2016 г. ПАО «Федеральная сетевая компания Единой энергетической системы» (ФСК ЕЭС) обеспечивает функционирование 139,1 тыс. км линий электропередачи и 924 подстанций с общей трансформаторной мощностью более 322 тыс. МВА и напряжением до 750 кВ. В связи с такой большой протяженностью ЛЭП России их подверженность и уязвимость для неблагоприятных погодных воздействий исключительно велики. Ливень со снегом, ураганный ветер, перепады температуры создают риски технологических нарушений в электросетевом распределительном комплексе.

\footnotetext{
${ }^{91}$ Elistratov V.V., Fedorov M.P., Akentyeva E.M., 2014: Hydraulic power engineering under conditions of probable climate changes. Power Technology and Engineering, v. 48, № 4, p. 277-283.
} 
Наибольшее число аварий отмечается в холодную часть года при сильном ветре и отложении гололеда. Гололедно-ветровые нагрузки вызывают не только обрывы проводов, но и разрушение несущих опор. В летний период особую опасность вызывают грозы и волны жары, так как при высоких температурах воздуха происходит растяжение проводов, при этом возможны их провисание и контакт с соседними проводами, вызывающий короткое замыкание.

Удельный ущерб при различной длительности перерывов электроснабжения отличается в зависимости от типа пользователей электроэнергии. Наибольший ущерб в результате перерывов электроснабжения отмечается в промышленных, строительных и транспортных видах экономической деятельности. Основная часть (75 \%) простоев в производственной деятельности, вызванных отключениями электроэнергии, составляет сутки и менее. Причиной перерывов энергоснабжения в $17 \%$ случаев являются природные факторы, из которых на долю погодных условий приходится 90 \%. Наиболее опасными для электросетевого хозяйства являются ветер и осадки (8 \% всех отключений) и молнии (7 \% всех отключений).

\subsection{4 Климатические риски для объектов инфраструктуры, связанные с деградацией многолетней мерзлоты}

Изменение климата вызывает увеличение температуры многолетнемерзлых грунтов (ММГ), уменьшение их прочностных свойств и интенсификацию ряда деструктивных геокриологических процессов, таких как термокарст, солифлюкция, неравномерные просадки почвы и т. п. ${ }^{92}$ Прогнозы указывают на то, что эти изменения будут усиливаться в последующие несколько десятилетий, в результате чего возникнут и со временем увеличатся риски повреждения и разрушения сооружений и транспортных коммуникаций в криолитозоне. В научной литературе приведены многочисленные примеры того, что эти процессы уже имеют место. ${ }^{93}$

В инженерной геокриологии разработаны эффрективные методы стабилизации фундаментов и дорожных покрытий при деградации ММГ, прежде всего, термосифоны и вентиляционные устройства, применение которых позволяет в течение некоторого времени, часто сопоставимого со сроком эксплуатации сооружений, компенсировать воздействие изменения климата. ${ }^{94}$ Стабилизирующие технологии сопряжены со значительными расходами, и их повсеместное применение экономически нецелесообразно. По этой причине высокую актуальность приобретают сопоставительные оценки несущей

\footnotetext{
${ }^{92}$ Гарагуля Л.С., Ершов Э.Д., (ред.), 2000: Геокриологические опасности. Природные опасности России, ред. В.И. Осипов, С.К. Шойгу. Т. 1., М.: Крук, 315 с.; Гребенец В.И., Ухова Ю.А., 2008: Снижение геотехнической надежности при ухудшении мерзлотных условий оснований, Основания, фундаменты и механика грунтов, № 5, с. 24-28.

${ }_{93}$ Streletskiy D.A., Anisimov O.A., Vasiliev A., 2014: Permafrost Degradation. In: W. Haeberly and C. Whiteman (Eds.). Snow and Ice-Related Hazards, Risks and Disasters. Chapter 10, Elsevier, p. 303-344.

${ }^{94}$ Попов А.П., Милованов В.И., Жмулин В.В., Рябов В.А., Бережной М.А., 2008: К вопросу о типовых технических решениях по основаниям и фундаментам для криолитозоны, Инженерная геология, № 3 , c. $22-40$.
} 
способности фрундаментов и оснований инженерных сооружений в различных регионах Крайнего Севера в условиях современных и ожидаемых в будущем изменений климата.

Устойчивость сооружений в криолитозоне зависит, главным образом, от того, находится ли температура грунта в пределах диапазона, заложенного при их проектировании. Согласно строительным нормам и правилам (СНиП), он рассчитывается по средним многолетним значениям климатических параметров. В расчет закладывается коэфффициент запаса, который для большинства сооружений в России (и ранее в СССР) не превышает 30-40 \%.

В контексте ресурсоориентированного развития экономики Арктических регионов России особенно важен вопрос об устойчивости инфраструктуры топливно-энергетического комплекса, которая включает в себя разветвленную сеть трубопроводов. Проведенные в США исследования показали, что для поддержания нормативной работоспособности существующей на Аляске инфраструктуры в период до 2030 г. потребуется от 3,6 до 6,1 миллиарда долларов и около 7,6 миллиардов в период до 2080 г. ${ }^{95}$. Хотя подобные перспективные оценки для России отсутствуют, можно предположить, что с учетом значительно большего числа инфраструктурных объектов в криолитозоне расходы на их поддержание будут более высокими. Уже сейчас только лишь на обслуживание трубопроводов в районах распространения ММГ в России ежегодно расходуется около 55 млрд рублей. ${ }^{96}$

Выборочные исследования, проведенные в отдельных арктических городах России, выявили многочисленные примеры повреждения зданий и сооружений на ММГ. ${ }^{97}$ Данные указывают на то, что в настоящее время число сооружений в криолитозоне, основания которых испытывают деструктивное воздействие, значительно увеличилось. Так, в Норильске количество зданий, получивших повреждения в последние 10 лет, оказалось выше, чем за предшествующие 50 лет. $^{98}$ Эти изменения можно сопоставить с имевшими

\footnotetext{
${ }^{95}$ Larsen P.H., Goldsmith S., Smith O., Wilson M.L., Strzepek K., Chinowsky P., Saylor B., 2008: Estimating future costs for Alaska public infrastructure at risk from climate change, Global Environmental Change, 18(3), p. 442-457.

${ }^{96}$ Streletskiy D.A., Shiklomanov N.I., Hatleberg E., 2012: Infrastructure and a Changing Climate in the Russian Arctic: A Geographic Impact Assessment Proceedings of the 10th International Conference on Permafrost, v. 1, p. 407-412.

97 Алексеева О.И., Балобаев В.Т., Григорьев М.Н., Макаров В.Н., Чжан Р.В., Шац М.М., Шепелев В.В., 2007: О проблемах градостроительства в криолитозоне (на примере Якутска), Криосфера Земли, № 2, с. 76-83; Стрелецкий Д.А., Шикломанов Н.И., Гребенец В.И., 2012: Изменение несущей способности мерзлых грунтов в связи с потеплением климата на севере Западной Сибири, Криосфера Земли, T. XVI, № 1, с. 22-32; Хрусталев Л.Н., Давыдова И.В., 2007: Прогноз потепления климата и его учет при оценке надежности оснований зданий на вечномерзлых грунтах. Криосфера Земли, т. ХІ, № 2, с. 68-75; Хрусталев Л.Н., Пармузин С.Ю., Емельянова Л.В., 2011: Надежность северной инфраструктуры в условиях меняющегося климата: монография. М: Университетская книга, 260 с.; Grebenets V.I., Streletskiy D.A., Shiklomanov N.I., 2012: Geotechnical safety issues in the cities of Polar Regions, Geography, Environment, Sustainability, 5(3), p. 104-119; Streletskiy D.A., Shiklomanov N.I., Nelson F.E., 2012: Permafrost, infrastructure and climate change: a GIS-based landscape approach to geotechnical modeling, Arctic, Antarctic, and Alpine Research, 44(3), p. 368-380.

${ }^{98}$ Grebenets V.I., Streletskiy D.A., Shiklomanov N.I., 2012: Geotechnical safety issues in the cities of Polar Regions, Geography, Environment, Sustainability, 5(3), p. 104-119.
} 
место изменениями температуры воздуха в криолитозоне России, региональные особенности которых рассмотрены в ряде работ. ${ }^{99}$

Анализ данных о среднегодовой температуре воздуха (рис. 3.5а), используемой при расчете нормативной нагрузки свайных фундаментов, позволяет оценить изменение их несущей способности за время, прошедшее после постройки сооружений (рис. 3.5б).

A)

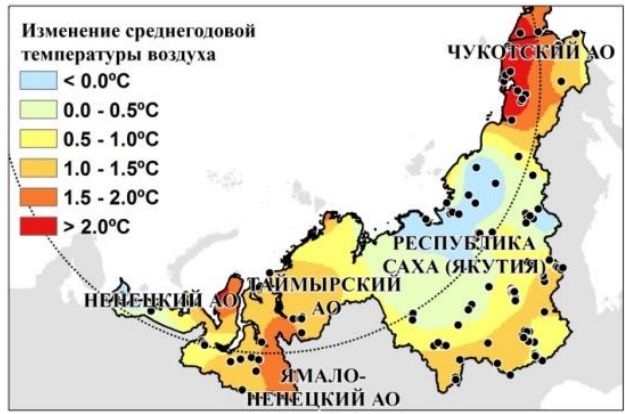

Б)

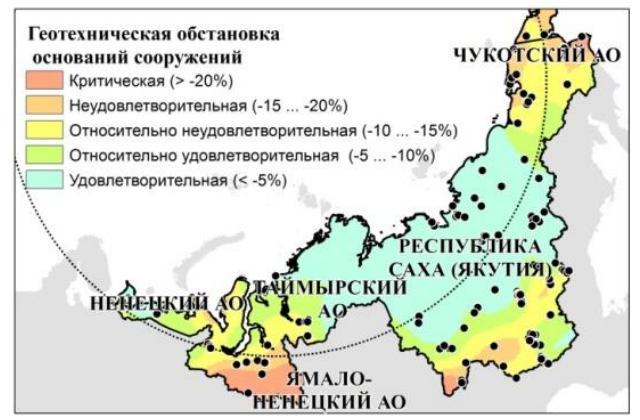

Рис. 3.5 Изменения среднегодовой температуры воздуха (А) и расчетной несущей способности свайных фундаментов (Б) в период между 1960-1970 гг. и 2000-2010 гг.

Таблица 3.1 Климатообусловленные изменения несущей способности свайных фундаментов в городах Российской Арктики за период эксплуатации сооружений, \%.

\begin{tabular}{c|c|c|c|c|c|c}
\hline \multirow{2}{*}{ Регион } & Город & \multicolumn{5}{|c}{ Несущая способность ММГ, \% } \\
\cline { 2 - 6 } & & $\begin{array}{c}1960- \\
1970\end{array}$ & 1980 & 1990 & 2000 & 2010 \\
\hline Западная & Салехард & 100 & $91-103$ & $72-86$ & $81-82$ & $68-70$ \\
Сибирь & Надым & 100 & $96-101$ & $77-91$ & $78-100$ & $64-95$ \\
& Новый Уренгой & - & - & 100 & $97-116$ & $91-96$ \\
& Новый Порт & 100 & $105-114$ & $86-93$ & $87-92$ & $63-76$ \\
Центральная & Норильск & 100 & $102-105$ & $88-93$ & $84-92$ & $85-94$ \\
Сибирь & Дудинка & 100 & $103-110$ & $93-94$ & $90-94$ & $74-82$ \\
Якутия & Якутск & 100 & $91-98$ & $80-92$ & $59-84$ & $54-80$ \\
& Тикси & 100 & $99-100$ & $96-98$ & $95-97$ & $93-96$ \\
Чукотка & Черский & 100 & $100-101$ & $97-98$ & 96 & $76-84$ \\
& Анадырь & 100 & $101-104$ & $92-100$ & $75-94$ & $52-84$
\end{tabular}

В табл. 3.1 приведены расчетные данные о динамике климатообусловленного изменения несущей способности свайных фундаментов для ряда городов Российской Арктики по десятилетиям, начиная с 1960-х гг.

Изменение климата повлияло на продолжительность эксплуатационного периода зимников и их несущую способность (рис. 3.6). Следует отметить неоднородность этих изменений в пределах криолитозоны. Так, с середины 1960-х гг. почти повсеместно в Якутии и в некоторых районах Центральной Сибири ежегодная продолжительность эксплуатации зимников увеличилась

\footnotetext{
99 Анисимов О.А., Жильцова Е.Л., 2012: Об оценках изменений климата регионов России в 20 и начале 21 веков по данным наблюдений. Метеорология и гидрология, № 6, с. 95-107; Anisimov O.A., Kokorev V.A., Ziltcova E.L., 2013: Temporal and Spatial Patterns of Modern Climatic Warming: Case Study of Northern Eurasia. Climatic Change, v. 118, № 3, p. 871-883.
} 
местами более чем на 10 дней. В то же время, она значительно сократилась во многих районах нефте- и газодобычи в Западной Сибири, в долине р. Енисея к северу от Игарки до Диксона, в районе г. Черский на северо-востоке Якутии, вблизи городов Певек и Анадырь на Чукотке. ${ }^{100}$ Согласно прогнозу ${ }^{101}$ к середине XXI в. в России на 13 \% сократится досягаемость удаленных поселков, в настоящее время обслуживаемых зимниками, при этом территория, на которой экономически целесообразно эксплуатировать зимники, уменьшится примерно на 1 млн км². На оставшихся зимниках сократится период эксплуатации, главным образом изменения произойдут в ноябре и апреле. При том, что с аналогичными транспортными проблемами сталкиваются все Арктические страны, в России они могут иметь наиболее сильные негативные последствия, поскольку, в отличие от Аляски и Северной Канады, у нас мало развит местный воздушный транспорт.

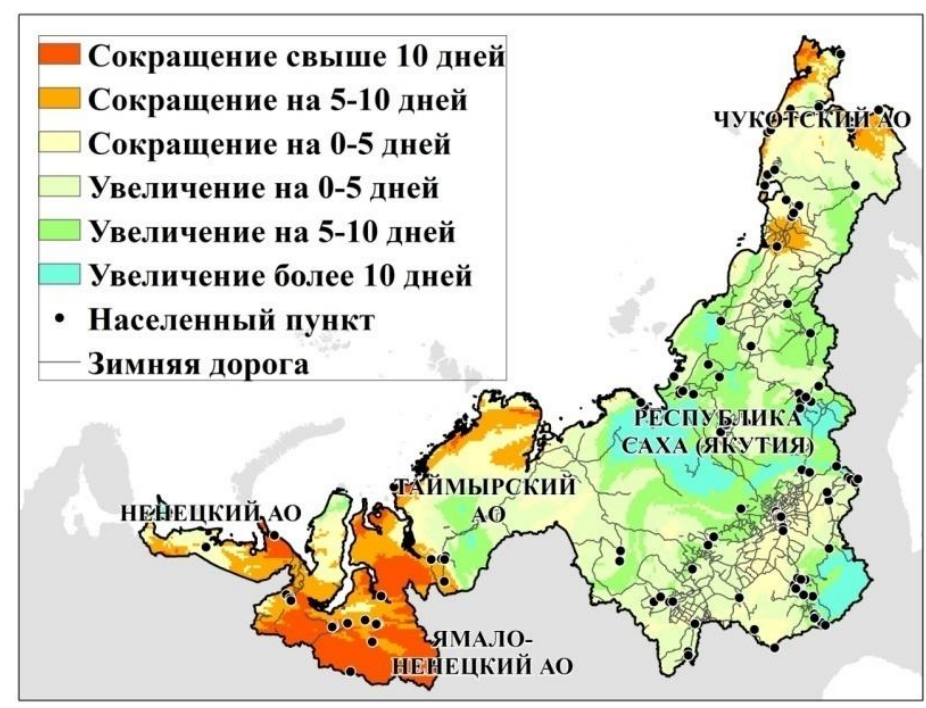

Рис. 3.6 Изменения расчетной продолжительности эксплуатации зимних дорог в период между 1965-1975 и 1995-2005 гг.

В ряде работ 102 были предложены расчетные индексы, которые позволяют количественно оценить уязвимость инженерных сооружений при таянии ММГ. Наибольшее распространение получил индекс геокриологических рисков, учитывающий относительное изменение мощности сезонно-талого слоя

\footnotetext{
${ }^{100}$ Streletskiy D.A., Shiklomanov N.I., Hatleberg E., 2012: Infrastructure and a Changing Climate in the Russian Arctic: A Geographic Impact Assessment Proceedings of the 10th International Conference on Permafrost, v. 1, p. 407-412.

${ }^{101}$ Stephenson S.R., Smith L.C., Agnew J.A, 2011: Divergent long-term trajectories of human access to the Arctic, Nature Climate Change, 1(3), p. 156-160.

102 Анисимов О.А., 2009: Вероятностно-статистическое моделирование мощности сезонно-талого слоя в условиях современного и будущего климата. Криосфера Земли, т. 8, № 3, с. 36-44; Анисимов О.А., Белолуцкая М.А., 2002: Оценка влияния изменения климата и деградации вечной мерзлоты на инфраструктуру в северных регионах России. Метеорология и гидрология, № 6, с. 15-22; Анисимов, О.А., Лавров С.А., 2004: Глобальное потепление и таяние вечной мерзлоты: оценка рисков для производственных объектов ТЭК, Технологии ТЭК, № 3, с. 78-83; Nelson F.E., Anisimov O.A., Shiklomanov N.I., 2001: Subsidence risk from thawing permafrost. Nature, № 410, p. 889-890; Nelson F.E., Anisimov O.A., Shiklomanov N.I., 2002: Climate change and hazard zonation in the circum-Arctic permafrost regions. Natural Hazards, v. 26, № 3, p. 203-225.
} 
по сравнению с условиями, заложенными в расчет при строительстве сооружения, объемной доли льда в мерзлом грунте, а также засоленности грунта (рис. 3.7).

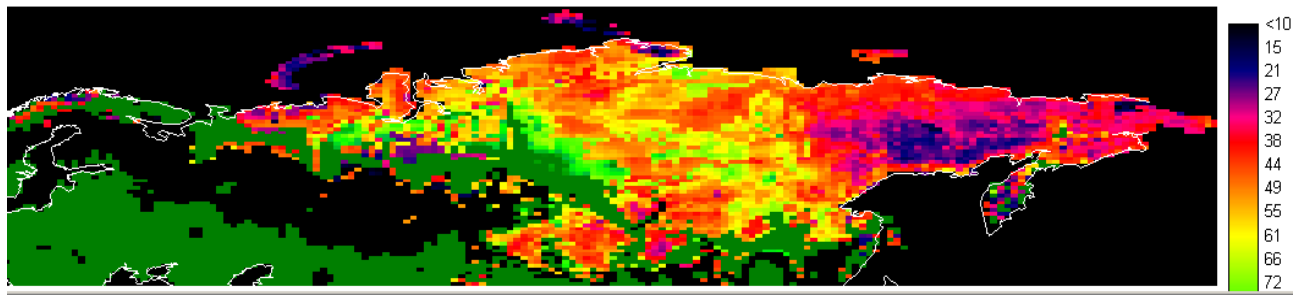

Рис. 3.7 Прогноз индекса геокриологических рисков на середину XXI в.

Расчет проведен с использованием оптимизированной климатической перспективной оценки по ансамблю моделей CMIP5.

В области наибольших рисков попадают Чукотка, бассейны верхнего течения Индигирки и Колымы, юго-восточная часть Якутии, значительная часть Западно-Сибирской равнины, побережье Карского моря, Новая Земля, а также часть криолитозоны с островным распространением ММГ на севере ЕЧР. В этих районах имеется развитая инфрраструктура, в частности газо- и нефтедобывающие комплексы, система трубопроводов Надым-Пур-Таз на северо-западе Сибири, Билибинская атомная станция и связанные с ней линии электропередач от поселка Черского на Колыме до города Певека на побережье Восточно-Сибирского моря. Деградация ММГ на побережье Карского моря может привести к значительному усилению береговой эрозии, в результате которой в настоящее время берег отступает ежегодно на 2-4 метра. Особую опасность представляет ослабление ММГ на Новой Земле в зонах расположения хранилищ радиоактивных отходов.

\subsection{5 Климатические риски для объектов инфраструктуры, связанные с динамикой ледников}

Объекты инфраструктуры, расположенные в гляциальной и перигляциальной зонах, подвержены воздействию

- гляциальных и гляциально-ливневых селей,

- гляциальных прорывных паводков,

- термокарстовых процессов в массивах мерзлоты и мертвых льдов,

- обвальных процессов с зонами отрыва в скальных породах, рыхлообломочных массивах и ледниках,

- снежных лавин,

- ледниковых и ледово-каменных лавин,

- лахаров (грязевых потоков) и гляцио-вулканогенных селей.

Потепление климата вызывает активизацию этих процессов,

вызывающих увеличение площадей зон поражения вследствие

- дегляциации территорий,

- вовлечения в обвальные, оползневые, термокарстовые и селевые процессы активизировавшихся участков мерзлотных массивов, 
- формирования новых озер и их прорывов,

- прорывов озер, длительное время не представлявших угрозы,

- увеличения дальности выброса снежных лавин, которые уничтожают даже 300-летние лесные массивы,

- вовлечения в обвальные процессы скальных массивов, которые ранее были скованы льдом, и увеличения дальности выброса каменных и ледово-каменных лавин,

- техногенного воздействия.

В результате активизации опасных процессов возникают новые угрозы объектам, ранее не подверженным их воздействию. Строительство новых объектов в опасных зонах сопряжено с проблемами, связанными с недооценкой возникающих новых угроз.

Созданные в XX в. карты опасностей и рисков не отражают современных угроз и зоны их поражения, а также масштабы возможных катастроф.

Вызов глобального потепления и связанных с ним опасных процессов объектам экономики и населению очень серьезен. Бороться с угрозами меняющейся природы чрезвычайно сложно. Недооценить и переоценить возникающие угрозы в одинаковой степени нежелательно.

Процессы, происходящие в высокогорной зоне, не увеличивают свою активность без конца. Наступает время, когда потенциал опасности исчерпывается в связи с тем, что прекращается действие фракторов, приводящих к катастрофам. В будущем может сложиться ситуация, когда уже осуществленные защитные мероприятия и строительство соответствующих сооружений, равно как и планируемые затраты, окажутся ненужными или неэффрективными.

При оценке угроз и рисков для объектов, расположенных в непосредственной близости от гляциально-перигляциальной зоны необходимо рассматривать варианты как увеличения рисков, связанных с расширением рекреационных территорий и объектов, так и уменьшения их.

Изучение условий формирования катастрофических селей позволило выявить важнейший механизм - прорывы внутриледниковых и подледниковых водоемов (рис. 3.8). Расходы гляциальных паводков 2000 и 2011 гг. многократно превысили расходы паводков ливневого генезиса.

Дальнейшее развитие гляциальной системы р. Кая-Арты-Су может привести к такому ее состоянию, при котором условий для формирования катастрофических гляциальных паводков не будет. Продолжение деградации ледников приведет к радикальному изменению системы гляциальных очагов, где очаги водных паводков, связанные ранее с блокировкой дренажной системы ледников и накоплением воды в леднике, прекратят свое существование. Для того чтобы подтвердить этот вывод и разработать концепцию защиты от селей на будущее, необходимо продолжение мониторинга ледниковой зоны бассейна реки Кая-Арты-Су, а также русловых и склоновых процессов. 


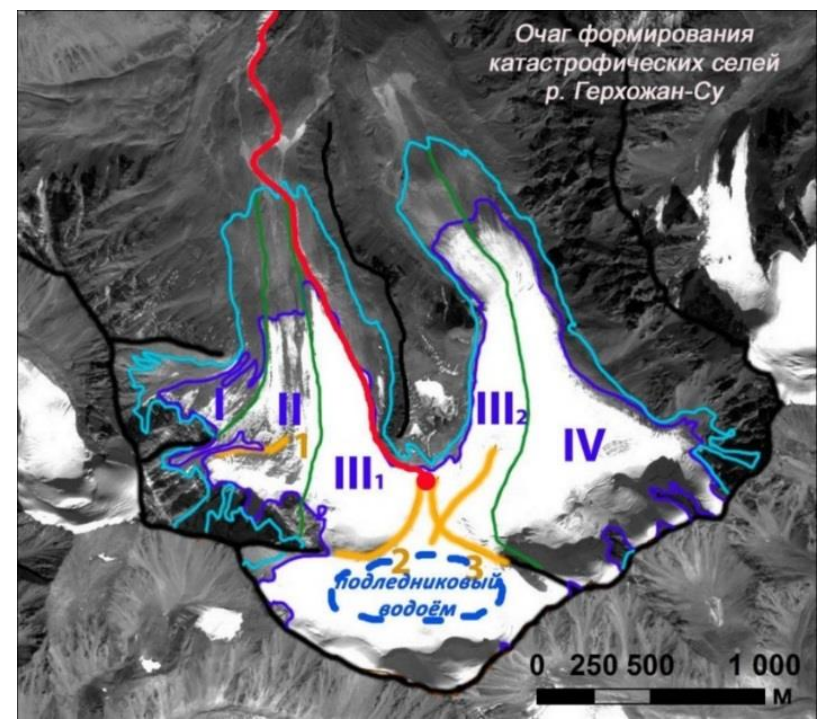

Рис. 3.8 Система потоков льда ледника Каяртыбаши (указаны римскими цифрами) и очаг водного паводка 2011 г., трансформировавшегося в сель. Арабские цифры и желтые линии - выступы коренного ложа (ригели).

Необходима разработка концепции развития самых высокогорных объектов рекреации - гостиниц, канатных дорог и горнолыжных трасс на склоне Эльбруса. Большая часть объектов расположена в зоне, где до настоящего времени снежный покров существовал практически круглый год, и все транспортные коммуникации обеспечивались снегоходным транспортом. С каждым годом ледники в этой зоне все дольше остаются без снежного покрова. Возможно, в ближайшем будущем наступит момент, когда ледники превратятся в мертвые льды и будут препятствовать транспортному сообщению с гостиницами (рис. 3.9).

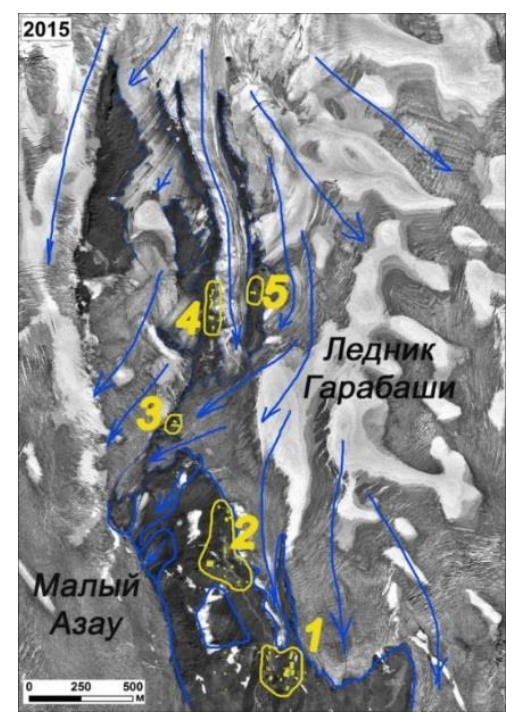

Рис. 3.9 Расположение гостиниц и объектов инфраструктуры (показаны желтым цветом) в районе ледников Малый Азау и Гарабаши на снимке Pleiades-1A/1B 23 августа 2015 г. 


\section{3 Сельское хозяйство}

Факторы уязвимости сельского хозяйства российских регионов, расположенных в разных природных и климатических зонах, заметно разнятся. Для северных и влажных регионов к факторам уязвимости можно отнести вторжение холодных воздушных масс с севера, избыточное увлажнение и заморозки, в более южных и сухих регионах - это волны тепла, засухи, пыльные бури, суховеи, ветровая и водная эрозия. ${ }^{103}$

Неблагоприятным следствием глобального потепления является повышение засушливости климата на значительной территории России. Увеличение частоты засух наблюдается не только в регионах с прогнозируемым снижением количества осадков, но и в областях, где количество осадков увеличивается вследствие изменения климата. ${ }^{104}$ В этих условиях на первое место выходит требование относительной устойчивости хозяйственных, т. е. заложенных в закрома, урожаев - небольшие колебания относительно среднего уровня неизбежны, но риски крупных недоборов продукции должны быть если не исключены, то, во всяком случае, сведены к минимуму.

Сельское хозяйство относится к тем отраслям экономики, которые наиболее чувствительны к изменениям климата. К опасным для сельского хозяйства явлениям относятся: засухи, суховеи, заморозки, переувлажнение почвы, градобития и некоторые другие, а также комплексы неблагоприятных гидрометеорологических явлений, вызывающих полегание посевов, резкое снижение их продуктивности, гибель и затрудняющих проведение полевых работ, особенно уборку урожая. $\mathrm{K}$ опасным относятся также гидрометеорологические явления холодного периода года, приводящие к вымерзанию, вымоканию и выпреванию озимых культур, а также к повреждению многолетних насаждений. ${ }^{105}$

В настоящем докладе основное внимание уделено рассмотрению климатических рисков в растениеводстве. При резко континентальном климате и огромной территории земледельческой зоны России климатическая обусловленность земледелия имеет решающее значение. Растениеводство как кормовая база определяет риски и в животноводстве. Косвенные риски в сфере животноводства, обусловленные изменениями климатических условий, могут быть связаны с нехваткой питьевой воды, болезнями и др., а к прямым рискам можно отнести перегрев животных при аномальных погодных условиях (аномально жаркая погода, суховеи). Животноводство в контексте климатической тематики в первую очередь рассматривается как источник парниковых газов (закиси азота и метана), т. е. относится к вопросам смягчения воздействия на климатическую систему.

\footnotetext{
103 Росгидромет, 2014.

104 Устойчивость земледелия и риски в условиях изменения климата (резюме коллективной монографии). СПб, 2009, 95 с.

${ }_{105}$ РД Росгидромета 52.88.699 Положение о порядке действий учреждений и организаций при угрозе возникновения и возникновении опасных природных явлений. М., Росгидромет, 2008.
} 
Следует особо отметить, что задачи, связанные с количественной оценкой рисков при производстве сельскохозяйственных культур (отдельные культуры, разные природно-климатические зоны и др.) на территории земледельческой зоны России, далеки от их полного и даже удовлетворительного решения и требуют дальнейших исследований.

\section{Прямые климатические риски в растениеводстве}

Применительно к производству сельскохозяйственных культур климатический риск можно определить как вероятность ожидаемых потерь урожайности, вытекающую из взаимодействия между неблагоприятными метеорологическими фракторами и уязвимостью реципиента (субъекта сельскохозяйственный район, область, край, республика). Вероятность оценивается как отношение числа лет с урожайностью ниже некоторого критического уровня к общему числу лет рассматриваемого периода. Для расчета оценок уязвимости может использоваться функция урожайности и биоклиматического потенциала. ${ }^{106}$

Валовый сбор зерновых и зернобобовых по России составил: в 2008 г. (предыдущий максимум) - 108 млн т, в 2016 г. (по предварительным оценкам максимальный за последние 20 лет) - 116 млн т и в 2010 г. - 61 млн т. Таким образом, недобор урожая, обусловленный засухой 2010 г., относительно максимальных валовых сборов в 2008 г. и 2016 гг. составляет 47-55 млн т (рис. 3.11). Агротехника и посевные площади сельскохозяйственных культур за этот период не могли существенно измениться, поэтому недобор зерна порядка 50-55 млн т (или 40-50 \% от действительного возможного урожая ${ }^{107}$ ) может служить верхней оценкой отклика урожайности на климатические изменения при современном уровне агротехнологий. Согласно А. М. Алпатьеву ${ }^{108}$, за критический уровень недобора урожайности может быть принято $40 \%$-е снижение урожайности относительно среднего за определенный ряд лет.

Расчет климатически обусловленной урожайности по динамической модели «Погода-Урожай» (табл. 3.3) выполнялся для 24 субъектов (область, край, республика), где средние посевные площади за период 1995-2015 гг., занятые яровой пшеницей, превышали 100 тыс. га. Посевные площади под яровой пшеницей к настоящему времени значительно сократились на этой территории по сравнению с базовым периодом 1961-1980 гг. При этом в целом по России за период 1995-2015 гг. посевные площади яровой пшеницы практически не изменились.

\footnotetext{
106 Павлова В.Н., Варчева С.Е., 2016: Анализ и оценка уязвимости и риска производства зерновых культур при современных изменениях климата в Калужском регионе. Труды регионального конкурса проектов фундаментальных научных исследований. Калужский государственный институт развития образования. Вып. 21, с. 246-251; Павлова В.Н., Варчева С.Е., 2017: Оценки степени уязвимости территории и климатического риска крупных неурожаев зерновых культур в зерносеющих регионах России. Метеорология и гидрология (в печати).

107 Принятый в агрометеорологии термин, предложенный Х.Г. Тоомингом (Тооминг Х.Г., 1984: Экологические принципы максимальной продуктивности посевов. Л.: Гидрометеоиздат, 263 с.)

${ }^{108}$ Алпатьев А.М., 1954: Влагооборот культурных растений. Л.: Гидрометеоиздат, 323 с.
} 


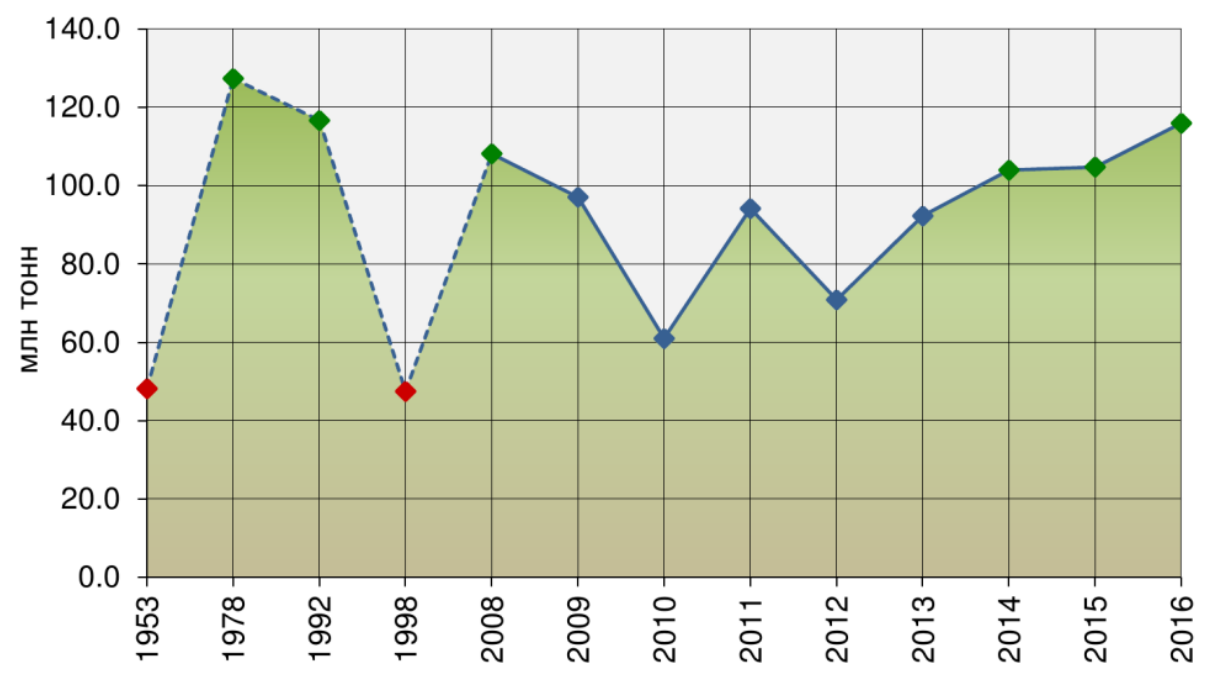

Рис. 3.11 Валовые сборы зерновых и зернобобовых культур в Российской Федерации, млн т. 109

Таблица 3.3 Посевные площади яровой пшеницы в основных ареалах ее возделывания и число случаев со значительным недобором $\left(N_{c r}\right)$ зерна по двадцатилетиям 1961-1980 и 1995-2015 гг.

\begin{tabular}{|c|c|c|c|c|c|c|c|}
\hline \multirow{2}{*}{$\begin{array}{c}\text { Субъект } \\
\text { Российской } \\
\text { Федерации: } \\
\text { край, область, } \\
\text { республика }\end{array}$} & \multicolumn{2}{|c|}{$\begin{array}{c}\text { Посевные } \\
\text { площади, тыс. га }\end{array}$} & \multirow{2}{*}{$\begin{array}{c}\text { Сокращение/ } \\
\text { увеличение } \\
\text { площадей } \\
\mathrm{S}_{95-15} / \mathrm{S}_{61-80}, \%\end{array}$} & \multicolumn{4}{|c|}{$\begin{array}{c}\text { Число неурожайных лет } \mathrm{N}_{\mathrm{cr}} \\
\text { с потерей урожайности } \\
20-40 \% \text { и более } 40 \%\end{array}$} \\
\hline & $\begin{array}{l}1995- \\
2015 \\
\text { гr. }\end{array}$ & $\begin{array}{l}1961- \\
1980 \\
\text { гr. }\end{array}$ & & $\begin{array}{c}20-40 \\
\%\end{array}$ & $\begin{array}{c}>40 \\
\%\end{array}$ & $\begin{array}{c}20-40 \\
\%\end{array}$ & $\begin{array}{c}>40 \\
\%\end{array}$ \\
\hline 1 & 2 & 3 & 4 & 5 & 6 & 7 & 8 \\
\hline & & & & \multicolumn{2}{|c|}{ 1961-1980 г2. } & \multicolumn{2}{|c|}{ 1995-2015 г2. } \\
\hline Алтайский & 2428 & 3943 & 62 & 4 & 0 & 3 & 2 \\
\hline Оренбургская & 1607 & 3066 & 52 & 3 & 2 & 3 & 6 \\
\hline Омская & 1472 & 1692 & 87 & 4 & 1 & 3 & 4 \\
\hline Новосибирская & 1211 & 1807 & 67 & 4 & 0 & 1 & 2 \\
\hline Курганская & 867 & 1389 & 62 & 1 & 5 & 2 & 5 \\
\hline Челябинская & 861 & 1260 & 68 & 3 & 1 & 1 & 6 \\
\hline Башкортостан & 804 & 1585 & 51 & 1 & 1 & 2 & 3 \\
\hline Красноярский & 706 & 1323 & 53 & 1 & 0 & 2 & 1 \\
\hline Татарстан & 546 & 825 & 66 & 3 & 2 & 4 & 3 \\
\hline Саратовская & 435 & 1896 & 23 & 3 & 2 & 3 & 4 \\
\hline Тюменская & 401 & 682 & 59 & 3 & 0 & 3 & 2 \\
\hline Кемеровская & 336 & 448 & 75 & 2 & 1 & 2 & 1 \\
\hline Иркутская & 279 & 609 & 46 & 0 & 0 & 2 & 0 \\
\hline Самарская & 237 & 921 & 26 & 4 & 2 & 0 & 6 \\
\hline Пермская & 189 & 332 & 57 & 2 & 2 & 3 & 0 \\
\hline Свердловская & 177 & 330 & 54 & 2 & 0 & 2 & 2 \\
\hline Читинская & 156 & 441 & 35 & 0 & 0 & 3 & 3 \\
\hline
\end{tabular}

${ }^{109}$ Росстат, 2016: http://www.gks.ru/wps/wcm/connect/rosstat.main/rosstat/ru/statistic/enterprise/economy . 


\begin{tabular}{l|c|c|c|c|c|c|c}
\hline \multicolumn{1}{c|}{$\mathbf{1}$} & $\mathbf{2}$ & $\mathbf{3}$ & $\mathbf{4}$ & $\mathbf{5}$ & $\mathbf{6}$ & $\mathbf{7}$ & $\mathbf{8}$ \\
\hline Томская & 147 & 175 & 84 & 2 & 0 & 1 & 1 \\
Волгоградская & 154 & 1297 & 12 & - & - & - & - \\
Ульяновская & 152 & 402 & 38 & - & - & - & - \\
Кировская & 144 & 134 & 107 & 2 & 0 & 3 & 0 \\
Пензенская & 125 & 342 & 37 & 5 & 4 & 2 & 2 \\
Нижегородская & 121 & 133 & 91 & 1 & 0 & 2 & 1 \\
Амурская & 108 & 421 & 26 & 0 & 0 & 3 & 0
\end{tabular}

Примечание.

1. Прочерки ( - ) обозначают, что расчеты не выполнялись из-за отсутствия метеорологических данных.

2. Красным цветом отмечено увеличение числа неурожаев в 1995-2015 гг. по сравнению с 1961-1980 гг., синим - уменьшение.

3. Расчеты выполнялись с помощью системы «Климат-Почва-Урожай». ${ }^{110}$ Технологическая составляющая исключена путем введения в модель параметров, фиксирующих уровень агротехники за заданный период (в данном случае за 20 лет). Период 1961-1980 гг. принят за «базовый», относительно которого выполнялся сравнительный анализ частоты неурожайных лет за последние два десятилетия. Показатель $N_{c r}$ определяется как число случаев с урожайностью ниже некоторого критического уровня $\left(Y_{c r}\right)$. Рассматриваются две градации недобора урожайности относительно средней величины урожайности за соответствующие два десятилетия: от 20 до 40 \% (значительный) и более $40 \%$.

Среди субъектов с посевными площадями свыше 700 тыс. га ее площади сократились практически вдвое: в Оренбургской области (52 \%), Республике Башкортостан (51\%) и Красноярском крае (53\%). В Волгоградской, Саратовской и Самарской областях, где яровой пшеницей было занято 9201900 тыс. га в 1961-1980 гг., средние посевные площади за последние 20 лет сократились до 12 \% в Волгоградской, 23 \% в Саратовской и 26 \% в Самарской областях. Процесс сокращения площадей связан не только с экономическими причинами, но в определенной мере объясняется изменением агрометеорологической ситуации в условиях происходящих изменений климата. ${ }^{111}$ Так, например, на юго-востоке Приволжского федерального округа, где сосредоточены значительные площади посевов яровой пшеницы, и в Волгоградской области в период 2001-2015 гг. по сравнению с 1986-2000 гг. условия увлажнения ухудшились, значения гидротермического коэффициента

110 Сиротенко О.Д., Абашина Е.В., Павлова В.Н., 1995: Чувствительность сельского хозяйства России к изменениям климата, химического состава атмосферы и плодородия почв. Метеорология и гидрология, № 4, с. 107-114; Сиротенко О.Д., 2007: Методы оценки изменений климата для сельского хозяйства и землепользования. Н.Новгород, 77 с.; Сиротенко О.Д., Груза Г.В., Ранькова Э.Я., Абашина Е.В., Павлова В.Н., 2007: Современные климатические изменения теплообеспеченности увлажненности агросферы на территории России. Метеорология и гидрология, № 8, с. 90-103; Сиротенко О.Д., Абашина Е.В., Павлова В.Н., 2009: Проблема оценки влияния изменений климата на продуктивность агросферы: модели, сценарии и результаты для сельского хозяйства России. Труды по прикладной ботанике, генетике и селекиии, вып. 166, с. 567-573.

${ }^{111}$ Росгидромет, 2017. 


\section{Г. Т. Селянинова ${ }^{112}$ (ГТК) уменьшились на 10-20\%, что отрицательно сказалось на урожайности зерновых культур. ${ }^{113}$}

Число неурожайных лет за период 1995-2015 гг. с превышением 40\%-го критического уровня снижения урожайности увеличилось в подгруппе субъектов с максимальными площадями: в Алтайском крае от 0 до 2, в Оренбургской области от 2 до 6 и в Омской области от 1 до 4. Если в Самарской и Саратовской областях в базовый период крупные недоборы случались дважды за двадцать лет, то за период 1994-2015 гг. - в четырех и шести случаях, соответственно. В целом за последние двадцать лет практически во всех рассмотренных субъектах частота или вероятность неурожайных лет с потерями выше 40 \% осталась либо практически без изменений, либо увеличилась. В градации потерь урожайности от 20 до 40 \% в 10 субъектах из 22 вероятность существенного снижения урожайности увеличилась, в пяти осталась неизменной и в семи субъектах уменьшилась.

Таким образом, сравнительных анализ числа лет с крупными потерями климатически обусловленной урожайности яровой пшеницы за периоды 1995-2015 и 1961-1980 гг. на большей части рассматриваемой территории выявил положительную динамику количества неурожайных лет этой культуры. Риск крупного недобора урожая яровой пшеницы увеличивается в основных регионах ее возделывания. Максимальные климатические риски значительных недоборов урожайности яровой пшеницы (20-30 \% или 4-6 случаев за 21 год) отмечаются в Оренбургской, Челябинской, Самарской, Саратовской, Омской и Курганской областях.

Многочисленные исследования показывают, что в Российской Федерации, как и во многих странах мира, наблюдается тенденция увеличения потерь в агропромышленном комплексе из-за усиливающихся воздействий опасных природных явлений. В связи с обширной территорией, большим разнообразием климатических и ландшафтных условий земледельческие районы России подвержены воздействию различных опасных метеорологических, агрометеорологических и гидрологических явлений. Из агрометеорологических опасных явлений наибольший ущерб зерновому хозяйству России наносят засухи, так как более 60 \% всех посевных площадей основных зерновых культур расположено в зонах недостаточного и неустойчивого увлажнения. Естественно, что в таких условиях угроза повреждений этих культур засухой в том или ином районе достаточно велика. Как известно, чаще всего эта угроза становится реальной в юго-восточных районах ЕЧР и сравнительно редко - в северных и западных.

Ущерб, наносимый сельскому хозяйству засухами, зависит от территории, охваченной ими, а также от интенсивности и продолжительности

\footnotetext{
${ }^{112}$ Селянинов Г.Т., 1966: Агроклиматическая карта мира. Л.: Гидрометеоиздат, 12 с.

113 Вильфанд Р.М., Страшная А.И., Береза О.В., 2016: О динамике агроклиматических показателей условий сева и зимовки и формировании урожая основных зерновых культур. Труды ГМЦ России, вып. 360 , c. $45-78$.
} 
периода засух. При локальных засухах зерновое хозяйство страны, как правило, не несет больших потерь. При обширных и интенсивных засухах ущерб, причиняемый ими, резко увеличивается, что вызывает необходимость четкого их отслеживания или мониторинга по определенным показателям или критериям. $^{114}$

В качестве критериев засух используются различные показатели, например, аномалии количества осадков (\% от климатической нормы) в сочетании с аномалией температуры воздуха, относительная влажность и дефицит влажности воздуха, запасы продуктивной влаги в почве или снижение урожайности относительно ее средней величины более чем на $20 \%{ }^{115}$ Распространены комплексные коэффициенты увлажнения (засушливости), представляющие собой в большинстве случаев отношение сумм осадков к испаряемости, где испаряемость учитывается косвенно по суммам температур или дефицита влажности воздуха. Среди таких показателей наиболее распространенным является гидротермический коэффициент Г. Т. Селянинова.

В работе ${ }^{116}$, где исследуются засухи в России, сформирована сводка сильных обширных засух продолжительностью не менее двух месяцев, которые охватывали три крупных района и более за период с 1891 по 2015 гг. (табл. 3.4). Обширной считалась засуха, которая была распространена в районе не менее чем на 30 \% территории. За период с 1946 по 2015 гг. для идентификации засух использовались как метеорологические данные, так и данные по урожайности зерновых культур с учетом их посевной площади, за более ранние годы использовались литературные источники.

Таблица 3.4 Районы, охваченные сильными и обширными засухами в России за период с 1891 по 2015 гг.

\begin{tabular}{|c|c|c|c|c|c|c|c|}
\hline 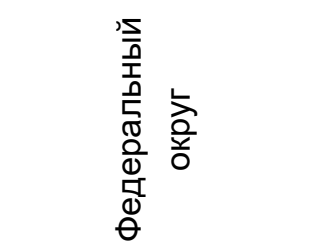 & 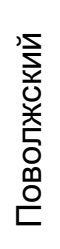 & 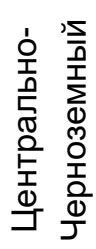 & 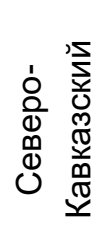 & 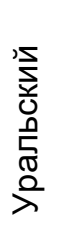 & 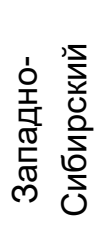 & 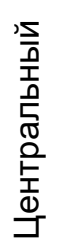 & 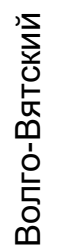 \\
\hline Число случаев & 33 & 26 & 24 & 24 & 16 & 12 & 13 \\
\hline Повторяемость, \% & 26 & 21 & 19 & 19 & 13 & 10 & 10 \\
\hline
\end{tabular}

В годы сильных и обширных засух прошлых лет снижение валовых сборов зерна в основных зернопроизводящих регионах достигало 40-50 \% и более по сравнению с годами, благоприятными по условиям увлажнения. За

\footnotetext{
114 Фролов А.В., Страшная А.И., 2011: О засухе 2010 года и ее влиянии на урожайность зерновых культур. Сб. докладов «Анализ условий аномальной погоды на территории России летом 2010 г.» М., Триада ЛТД, с. 22-31.

115 Алпатьев А.М., 1954: Влагооборот культурных растений. Л.: Гидрометеоиздат, 323 с.; Дроздов О.А., 1980: Засухи и динамика увлажнений. Л.: Гидрометеоиздат, 92 с.; Мещерская А.В., 1988: О показателе засух и урожайности зерновых культур. Метеорология и гидрология, № 2, с. 91-98; Раунер Ю.Л., 1981: Климат и урожайность зерновых культур. М.: Наука, 163 с.

${ }^{116}$ Страшная А.И., Максименкова Т.А., Чуб О.В., 2011: Агрометеорологические особенности засухи 2010 года в России по сравнению с засухами прошлых лет. Труды ГМЦ России, вып. 345, с. 194-214.
} 
последние 30 лет в годы с сильными и обширными засухами, в целом по Российской Федерации, валовые сборы зерна также уменьшались почти наполовину. Так, например, в сильные засухи 1981, 1995, 1998, 2010 и 2012 гг. валовые сборы составляли соответственно 73,8; 63,4; 47,9; 60,9; 70,9 млн т, тогда как в годы, благоприятные по условиям увлажнения (1993, 1997, 2002 , $2008,2014,2015)$ в основных районах они были, соответственно, 99,1; 88,6; 86,6; 108,2; 105,3; 104,8 млн т, а в 2016 г. по предварительным данным 116,0 млн т. Следует отметить, что в 1995 и 1998 гг. уменьшение валовых сборов было обусловлено не только засухой, но еще и сокращением посевных площадей под зерновыми культурами (по сравнению с 1981 г. почти на 12-15 млн га). Более показательной величиной для сравнительной оценки в таких случаях (при изменении посевных площадей) является урожайность. В указанные выше годы (1981, 1995, 1998, 2010 и 2012) средняя по Российской Федерации урожайность зерновых культур составла соответственно 10,0; 11,6; 9,4; 14,1 и 15,9 ц/га, а в благоприятные $(1993,1997,2002,2008,2014$ и 2015) 16,$3 ; 16,5 ; 18,6 ; 23,1 ; 22,8$ и 22,5 ц/га. ${ }^{117}$ Понятно, что ввиду столь резких колебаний урожайности и валовых сборов зерна правильная и своевременная оценка интенсивности засухи и ее возможных последствий (недобора урожая) в значительной степени может определять продовольственную безопасность как отдельных регионов, так и страны в целом, учитывая возможность выбора с большой заблаговременностью стратегии закупки зерна на рынках внутри страны или за ее пределами. Такая оценка необходима и для различных экономических расчетов, и для планирования деятельности сельскохозяйственных товаропроизводителей.

Достаточно объективной оценкой засухи для любой территории может служить причиняемый ею ущерб, который можно определить по величине снижения урожайности. Однако урожайность в конкретной природноклиматической зоне изменяется не только под воздействием погоды, но и в связи с изменениями, происходящими в культуре земледелия.

Для сравнительной оценки интенсивности засух и ущерба от них осуществлен выбор лет с локальными минимумами урожайности за период с 1951 по 2015 гг. Приведенные в табл. 3.5 оценки потерь урожайности от засух рассчитаны для современного уровня земледелия. Данные расчетов показывают, что засуха 2010 г. в ЕЧР привела к недобору порядка 50 \% урожая (валового сбора) яровой пшеницы, что превышает потери от засух 1972 и 1981 гг., составивших соответственно 43 и $49 \%$ от уровня урожая 2008 г. (табл. 3.5). Можно утверждать, что за последние 20 лет засуха 2010 г. оказалась наиболее значимой по расчетным потерям урожайности яровой пшеницы.

Крупномасштабная засуха 2010 г. привела к значительному снижению урожайности яровых зерновых культур практически на всей ЕЧР, особенно на юго-востоке территории (рис. 3.12). В 2010 г. расчетная климатически

\footnotetext{
${ }^{117}$ Страшная А.И., Максименкова Т.А., Чуб О.В., 2011: Агрометеорологические особенности засухи 2010 года в России по сравнению с засухами прошлых лет. Труды ГМЦ России, вып. 345, с. 194-214.
} 
обусловленная урожайность яровых зерновых культур была ниже соответствующей урожайности 2008 г. более чем на 80 \% в Самарской, Оренбургской, Пензенской, Саратовской областях и Республике Татарстан. Значительные потери урожайности зерновых культур, превышающие 60-70 \% по сравнению с 2008 г., наблюдались в Республике Башкортостан, Мордовии, Чувашии и Калмыкии, а также в Курской, Липецкой и Тамбовской областях, Краснодарском и Ставропольском краях.

Таблица 3.5 Оценка потерь (\%) урожайности яровой пшеницы в засушливые годы относительно 2008 г. «Система Климат-Почва-Урожай».

\begin{tabular}{l|c|c|c|c|c|c|c|c|c}
\hline \begin{tabular}{l} 
Федеральный \\
\multicolumn{1}{c|}{ округ }
\end{tabular} & \multicolumn{10}{|c}{ Год } \\
\cline { 2 - 9 } & $\mathbf{1 9 5 1}$ & $\mathbf{1 9 7 2}$ & $\mathbf{1 9 7 5}$ & $\mathbf{1 9 8 1}$ & $\mathbf{1 9 9 5}$ & $\mathbf{1 9 9 8}$ & $\mathbf{2 0 1 0}$ & $\mathbf{2 0 1 2}$ & $\mathbf{2 0 1 3}$ \\
\hline Центральный & $-16,1$ & $-45,9$ & $-36,1$ & $-53,3$ & $-25,6$ & $-34,2$ & $-50,5$ & $-19,9$ & $-35,1$ \\
Сев.-Западный & 0,5 & $-39,7$ & 2,0 & $-24,3$ & $-9,7$ & $-13,5$ & $-35,8$ & $-7,4$ & $-20,8$ \\
Приволжский & -22.0 & $-35,6$ & $-44,0$ & $-58,1$ & $-28,9$ & $-60,0$ & $-61,8$ & $-27,8$ & $-38,9$ \\
Южный & $-18,1$ & $-52,3$ & $-49,0$ & $-59,6$ & $-30,3$ & $-43,0$ & $-54,6$ & $-54,6$ & $-61,7$ \\
ЕчР & -13.9 & $-43,4$ & -31.8 & $-48,8$ & $-23,6$ & $-37,7$ & $-53,0$ & $-25,8$ & $-38,0$ \\
Уральский & 27,5 & 72,8 & $-7,5$ & $-5,2$ & 27,2 & $-28,5$ & $-11,8$ & $-15,6$ & 14,4 \\
Сибирский & 12,2 & 50,4 & 0,9 & 9,2 & 19,9 & $-8,5$ & 18,5 & $-18,6$ & 28,4 \\
Д.-Восточный & 47,9 & 60,5 & 39,5 & 54,6 & 36,5 & 44,4 & 10,9 & 8,3 & 25,0
\end{tabular}

Сопоставление контрастных по агрометеорологическим условиям, но хронологически близких лет, неурожайного 2010 г. и рекордных по урожайности 2008 и 2016 гг., дает возможность оценить диапазон влияния погодных условий на продуктивность сельского хозяйства России при мало изменявшемся уровне агротехники в большинстве зерносеющих регионов. Уменьшение валового сбора зерна на 50-55 млн т (более чем в два раза) может служить оценкой возможного диапазона воздействия межгодовой изменчивости климата на продуктивность сельского хозяйства России.

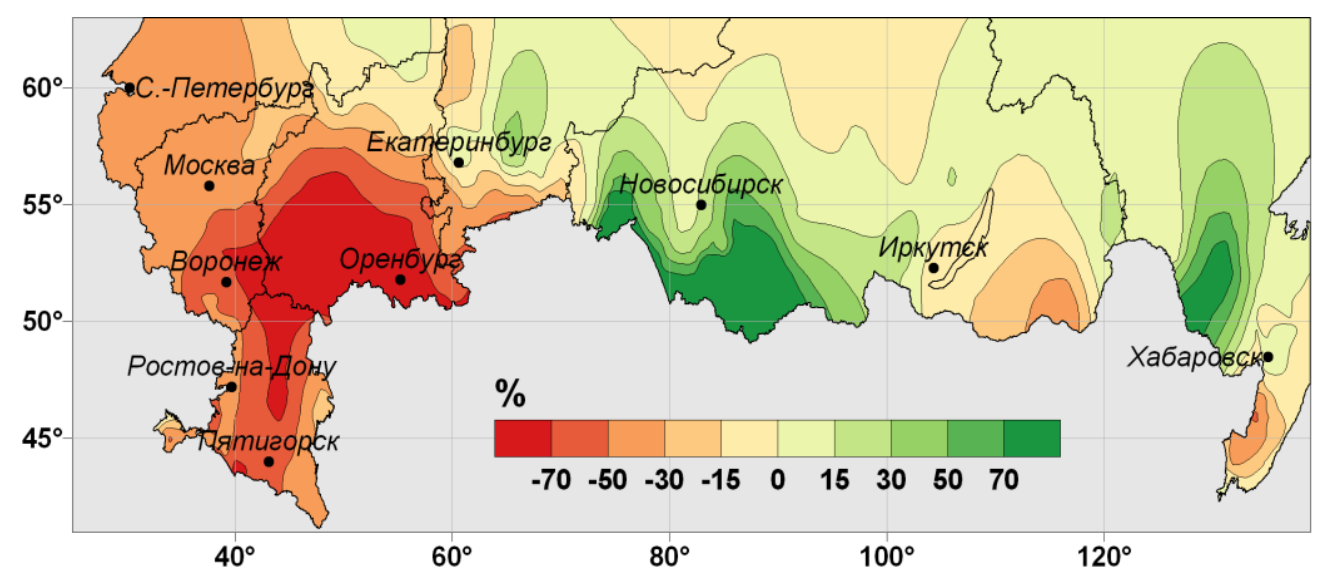

Рис. 3.12 Отклонения (\%) климатически обусловленной урожайности яровой пшеницы в 2010 г. от уровня урожайности 2008 г. Система «Климат-Почва-Урожай». 
Важнейшие для сельского хозяйства ожидаемые изменения климата сводятся к следующему:

- росту теплообеспеченности сельскохозяйственных культур и росту продолжительности вегетационного периода;

- повышению зимних температур воздуха, определяющих условия перезимовки сельскохозяйственных культур;

- изменению условий увлажнения, которые обуславливаются ростом количества осадков в холодный период года и уменьшением осадков в теплый период года.

В то время как в среднемировом масштабе изменения климата порождают тенденцию к снижению урожайности зерновых культур, на территории России наблюдается ее рост. Самыми высокими темпами (2,2-2,6 \% за 10 лет) росли урожаи зерновых в Приволжском и Южном федеральных округах. Повсеместно во всех регионах возделывания увеличивалась урожайность озимой пшеницы (в Приволжском и Южном федеральных округах на 2,8 и 2,0 \% за 10 лет). Отмечался климатически обусловленный рост урожайности подсолнечника и сахарной свеклы. Заметно возрастала урожайность кукурузы в Приволжском и Центральном федеральных округах, однако одновременно наблюдалось сокращение ее урожайности в Южном федеральном округе вследствие усиления засушливости в летний период. В Приволжском, Южном, Уральском, Сибирском и Дальневосточном федеральных округах зафиксирован климатически обусловленный рост урожайности зерновых культур со скоростью 1,6-2,6 \% за 10 лет. Исключение составляет Центральный федеральный округ, где наблюдались разнонаправленные изменения урожайности, обусловившие отрицательный климатически обусловленный тренд урожайности зерновых культур $\left(-0,3 \%\right.$ за 10 лет). ${ }^{118}$

Полученные в настоящее время оценки по многим сценариям изменений климата дают совпадающие в целом результаты - на территории нечерноземной зоны ожидается рост теплообеспеченности сельскохозяйственных культур, биоклиматического потенциала и запасов органического углерода в пахотных почвах. Как следствие этого возможен устойчивый рост продуктивности сельского хозяйства до середины XXI в.

Ожидаемые изменения климата и природной среды в первой половине XXI в. приведут как к положительному, так и к отрицательному воздействию на продуктивность сельскохозяйственных культур. Однако значительное положительное влияние на сельское хозяйство России они могут оказать только при условии заблаговременной адаптации на федеральном уровне аграрного сектора экономики к ожидаемым изменениям природной среды и климата.

\footnotetext{
${ }^{118}$ Павлова В.Н., Сиротенко О.Д., 2012: Наблюдаемые изменения климата и динамика продуктивности сельского хозяйства России. Труды Главной геофизической обсерватории им. А.И. Воейкова, вып. 565, c. $132-151$.
} 
При дальнейшем потеплении климата в России может усилиться неблагоприятное воздействие вредителей и возбудителей болезней сельскохозяйственных культур на валовые сборы и качество продукции растениеводства, так как эти организмы существенно зависят от климата. В первую очередь это связано со смещением изолиний сумм активных и эффективных температур воздуха и среднегодовых температур, ограничивающих их распространение, а также с увеличением зимних температур воздуха в Сибири и на Севере России. Сокращение районов с многолетней мерзлотой и увеличение толщины снежного покрова в Сибири способствует большей выживаемости различных сельскохозяйственных вредителей и патогенов в зимний период. ${ }^{119}$

При потеплении могут сместиться границы ареалов, возрасти численность, измениться число воспроизводимых поколений за сезон, расшириться круг растений-хозяев ${ }^{120}$ многих климатозависимых сельскохозяйственных вредителей и патогенов. Все это будет способствовать повышению их вредоносности и увеличению причиняемого ими ущерба сельскохозяйственному производству.

Очень часто совместное действие антропогенного фактора и климатических аномалий приводит к нарастанию численности саранчовых, нередко - к катастрофическому. В настоящий момент (начиная с 2008 г.) наблюдается очередной подъем их численности. В отдельных районах Астраханской, Волгоградской, Воронежской, Челябинской, Ростовской, Оренбургской областей, республиках Калмыкия, Башкортостан и Ставропольском крае объявлялись режимы угрозы чрезвычайной ситуации. Произошло существенное расширение ареала нестадных саранчовых на территории Сибири и Дальнего Востока. ${ }^{121}$

В последние годы стали происходить вспышки массового размножения мароккской саранчи, причем не только в привычных для нее регионах, но и там, где она раньше никогда не наблюдалась, - в отдельных районах Ставрополья и Калмыкии. ${ }^{122}$ Таким образом, возросли риски вспышек массового размножения мароккской саранчи на территории Северо-Кавказского, Южного и Приволжского Федеральных округов России. Существуют риски возникновения вспышек массового размножения и других видов вредных саранчовых итальянского пруса, азиатской саранчи и отдельных нестадных видов - на территории отдельных субъектов Приволжского, Уральского, Центрального, Дальневосточного федеральных округов.

\footnotetext{
${ }^{119}$ Росгидромет, 2014.

120 Т. е. растений, служащих источником питания, средой обитания и развития для вредных организмов.

${ }^{121}$ Росгидромет, 2014.

122 Саранчовые вредители, 2012. Фитосанитарный мониторинг. Защита растений. Официальный сайт ФГБу «Россельхознадзор», www.rosselhoscenter.ru/index.php/.../231-saranchovye-vrediteli; Обзор фитосанитарного состояния посевов сельскохозяйственных культур в Российской Федерации в 2012 году и прогноз развития вредных объектов в 2013 году. 2013. Ред. Д.Н. Говоров, А.В. Живых. М., 501 с.
} 
Колорадский картофельный жук по уровню его численности и вредоносности относится к числу супердоминантных видов насекомыхвредителей сельскохозяйственных растений. Он способен снизить урожай клубней картофреля на $30 \%$ и более. ${ }^{123}$ До настоящего времени ареал вредителя окончательно не сорормировался и продолжает расширяться, преимущественно в восточном и северо-восточном направлениях. Существуют риски распространения колорадского жука на территории тех регионов России, которые расположены вдоль прохождения северных, северо-восточных и восточных границ ареала вредителя. К этим территориям относятся республики Карелия, Коми, Архангельская область (Северо-Западный федеральный округ), Тюменская область (Уральский федеральный округ), Красноярская, Иркутская области, Республики Бурятия и Тыва, Забайкальский край (Сибирский федеральный округ), а также Амурская, Камчатская, Сахалинская области и Хабаровский край (Дальневосточный федеральный округ). ${ }^{124}$

При потеплении климата наблюдаются увеличение агрессивности и вредоносности отдельных представителей вредителей и возбудителей болезней сельскохозяйственных растений и изменение их экологических особенностей: смещение фаз развития на более ранние сроки, увеличение количества генераций за сезон на той же территории, смена пищевых предпочтений. В районах повышенного риска находятся территории вдоль северных, северо-восточных и восточных границ современных ареалов опасных сельскохозяйственных вредителей и патогенов. Вслед за потеплением климата в Сибири и в северных регионах России будет происходить расширение границ ареалов многих вредителей и возбудителей болезней сельскохозяйственных растений. Массовому размножению саранчовых на юге России будет благоприятствовать ожидаемое там увеличение интенсивности и количества засух.

Таким образом, ожидаемое изменение климата в XXI в. будет способствовать дальнейшему расширению границ ареалов и зон массового размножения различных вредителей и возбудителей болезней сельскохозяйственных растений, а также усилению их агрессивности и вредоносности.

\section{4 Водное хозяйство}

Риски в водном хозяйстве, вызванные изменениями климата, связаны, прежде всего, с изменениями речного стока - его снижением или увеличением в том или ином регионе. Снижение стока отражается непосредственно на объемах использования воды в различных отраслях экономики и водообеспеченности населения в регионах с дефицитом водных ресурсов;

\footnotetext{
123 Захаренко В.А., 2006. Рекомендации по предотвращению рисков чрезвычайных ситуаций биогенного характера, вызываемых вредными организмами. М., РАСХН, 110 с.; Павлюшин В.А., Сухорученко Г.И., Фасулати С.Р., Вилкова Н.А. 2009. Колорадский жук: распространение, экологическая пластичность, вредоносность, методы контроля. Приложение к журналу: Защита и карантин растений, № 3, 32 с.

124 Росгидромет, 2014.
} 
увеличение речного стока ведет к росту вероятности опасных гидрологических явлений а, следовательно, и к увеличению экономических ущербов.

\section{Водные ресурсы}

Среднемноголетние возобновляемые водные ресурсы страны (1936-2016 гг.) оцениваются в 4350 км³/год, в том числе из сопредельных государств на территорию России в среднем поступает немногим более 200 км³/год. На одного жителя нашей страны приходится около 30 тыс. м³/год общих ресурсов речного стока. Однако распределение ресурсов поверхностных вод крайне неравномерно по территории. Так в ЕЧР, где сосредоточено $80 \%$ населения страны, водные ресурсы составляют всего $21 \%$ общих водных ресурсов. В центральной и южной частях ЕЧР обеспеченность водными ресурсами в десятки раз меньше по сравнению с азиатской частью страны. В азиатской части сток только четырех крупнейших рек (Енисей, Лена, Обь и Амур) составляет 48 \% всего объема речного стока страны.

Водные проблемы регионов с низкой обеспеченностью усугубляются загрязненностью поверхностных вод в результате сбросов неочищенных и недостаточно очищенных промышленных и бытовых сточных вод, а также поверхностных вод с сельскохозяйственных угодий.

Водные ресурсы испытывают значительные межгодовые изменения. Важнейшей особенностью происходящих изменений является большая чувствительность территории России к изменениям глобального климата по сравнению с Северным полушарием и Земным шаром в целом. За период 1976-2016 гг. коэффицциент линейного тренда осредненной по территории России среднегодовой температуры составил $0,45{ }^{0} \mathrm{C} / 10$ лет, что в 2,5 раза превышает скорость потепления в целом для Земного шара. ${ }^{125} \mathrm{Ha}$ фоне современного потепления водные ресурсы страны были несколько выше, чем ранее. Так в среднем за период 1981-2016 гг. ресурсы речного стока страны составили $4480 \mathrm{~km}^{3} /$ год, что на $220 \mathrm{~km} 3 /$ год больше, чем в 1936-1980 гг. В значительной степени это было обусловлено повышенным стоком рек бассейна Северного Ледовитого океана.

Вместе с тем, в конце прошлого - начале текущего столетия на ряде рек наблюдалось длительное маловодье. Так, в бассейне р. Дон в течение последних 10 лет годовой сток был ниже нормы, а в 2015-2016 гг. снизился до значений, близких к минимальным за весь период наблюдений (1891-2016 гг.). В результате водохранилище Цимлянской ГЭС не наполнилось до необходимых отметок, что привело резкому снижению объемов грузопассажирских перевозок на Нижнем Дону, ухудшению экологического состояния реки и заставило ограничить водопотребление всех категорий пользователей.

Экстремальное по длительности маловодье наблюдается на реках бассейна оз. Байкал. Годовой сток р. Селенга, дающий около 60 \% притока речных вод в озеро в период с 1999 по 2016 гг., за исключением 2013 г., был меньше нормы, что, естественно, привело к снижению уровня Байкала и

\footnotetext{
125 Доклад об особенностях климата на территории Российской Федерации в 2016 году. - М., 2017, 70 с.; http://climatechange.igce.ru/.
} 
сокращению стока р. Ангары. Эта маловодная фраза явилась причиной возникновения целого комплекса водохозяйственных и экологических проблем, что потребовало приостановления действия постановления Правительства Российской Федерации от 26 марта 2001 г. № 234 «О предельных значениях уровня воды в озере Байкал при осуществлении хозяйственной и иной деятельности».

Определенные проблемы с гарантированным водообеспечением отдельных отраслей экономики возникли в бассейне Волги, особенно в его верхней части, в маловодные 2014 и 2015 гг. Однако анализ данных по гидрометрическим постам, имеющим наиболее продолжительные ряды наблюдений (137 лет), указывает на отсутствие каких-либо направленных тенденций в многолетних изменениях водных ресурсов рек бассейна Волги.

Вместе с тем, следует отметить факт формирования в последние годы экстремальных (максимальных и минимальных) за многолетний период водных ресурсов в бассейнах ряда крупнейших рек и в пределах отдельных регионов страны, что может свидетельствовать об увеличении их изменчивости. Например, годовой сток Енисея в 2011 г. был наибольшим $\left(732\right.$ км $\left.^{3}\right)$, а в 2016 г. - самым низким за период инструментальных наблюдений (483 км³), а Амура, соответственно, - в $2013\left(464 \mathrm{kм}^{3}\right)$ и 2008 (184 км³) годах. При этом межгодовая амплитуда годовых объемов стока составила для Енисея 249 км³, а для Амура - 300 км³ $^{3}$

Климатические изменения оказывают очень значительное влияние и на внутригодовое распределение стока. В течение последних 40 лет на реках страны отмечается увеличение стока в зимний период года. При этом, что крайне важно, самые большие изменения происходят на той части ЕЧР, которая наименее обеспечена водными ресурсами, где увеличение водности рек в холодный сезон достигает 50-120\%. Здесь выявлены значимые положительные тренды зимнего стока, при этом существенно увеличилась его изменчивость. Столь значительное повышение стока, наблюдающееся в течение нескольких десятилетий, свидетельствует о том, что условия его формирования существенно изменились под воздействием климата. Этот вывод подтверждается результатами анализа данных наблюдений на специализированной сети Росгидромета (воднобалансовые и болотные станции), а также фризико-математического моделирования процессов миграции и инфильтрации влаги в промерзающих и оттаивающих почвах. Установлено, что сток рек в течение зимнего периода возрастает, а запасы воды в снежном покрове к началу весны уменьшаются, что создает условия для снижения стока весеннего половодья. Так, на реках бассейна Балтийского моря (за исключением северной и северо-восточной его частей), Волги, Дона, Днепра в последние десятилетия весенний сток уменьшился на 10-30\%.

Увеличение летне-осеннего стока отмечается также на значительной части территории России, причем наиболее отчетливо этот процесс проявился на реках южной части лесной зоны, а также в лесостепной и степной зонах ЕЧР.

Установленные направленности изменений водных ресурсов по территории России, выявленные тенденции последних десятилетий в использовании воды основными потребителями - промышленностью, сельским 
и коммунальным хозяйствами, существующая динамика численности населения в субъектах Российской Федерации, а также перспективные планы экономического развития страны позволили оценить возможные риски в водном хозяйстве, связанные с изменениями климата на территории России.

\section{Водопотребление}

Водопотребление или использование воды зависит, главным образом, от социально-экономической ситуации в стране. Начиная с середины 80-х годов прошлого столетия, когда водопотребление достигало максимальных значений 110-115 км³/год, оно неуклонно снижалось и в 2016 г. составило 54,7 км 3 год. $^{126}$ Даже предполагая, что в среднесрочной перспективе рост водопотребления произойдет за счет развития водоемких отраслей промышленности и орошения в сельском хозяйстве, можно ожидать постепенного роста и достижения показателей водопотребления на различные нужды не более, чем до уровня 2000 года, наиболее благополучного периода между двумя кризисами 90-х годов прошлого столетия, и конца 2000-х, когда объем используемой воды составлял $61,3 \mathrm{~km}^{3} /$ год. При этом необходимо ориентироваться на стратегии тех отраслей, которые будут являться приоритетами в развитии экономики, особенно во вновь осваиваемых регионах страны. Это, прежде всего, энергетическая отрасль, расходующая до 80 \% объема промышленного водопотребления, и агропромышленный комплекс, в частности, орошаемое земледелие, т. е. те отрасли, продукцию которых при современном технологическом уровне не удается производить с малыми затратами воды и которые предполагается активно развивать в регионах, богатых водными ресурсами. Согласно Энергетической стратегии России на период до 2030 г. ${ }^{127}$ к 2020 году производство электроэнергии на ТЭС и АЭС должно возрасти по сравнению с современным периодом на 70 \% и составить 1485 млрд кВт•ч, а рост забора воды в соответствии с Водной стратегией ${ }^{128}$ за этот период

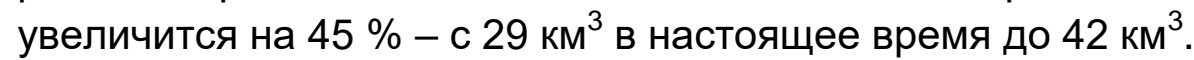

В сельском хозяйстве самый крупный водопотребитель - орошаемое земледелие. В соответствии с ФЦП «Развитие комплексных мелиораций и повышение продуктивности мелиорируемых земель» 129 наибольшее увеличение орошения запланировано в Сибири и на Дальнем Востоке - в бассейне рек Оби, Енисея и Амура, где намечается в перспективе довести площадь орошаемых земель до 800 тыс. га, что почти в 3 раза больше, чем в настоящее время. Значительный прирост орошаемых площадей планируется в бассейне р. Волги, особенно на территории Средней и Нижней Волги, а также в бассейне р. Камы.

В бассейне Дона намечается увеличение площадей орошаемых земель в Воронежской и Липецкой областях, полностью расположенных в бассейне

\footnotetext{
126 Основные показатели охраны окружающей среды. Статистический бюллетень. М., 2017.

127 Энергетическая стратегия России на период до 2030 года. 2009.

128 Водная стратегия Российской Федерации до 2020. 2011.

129 Федеральная целевая программа «Развитие комплексных мелиораций и повышение продуктивности мелиорируемых земель», утвержденная постановлением Правительства РФ 12.10.2013.
} 
Дона, а также в других областях (Белгородской, Курской, Тамбовской, Пензенской и Волгоградской), которые только частично относятся к бассейну.

На юге России дальнейшее увеличение орошаемых площадей практически не предполагается ввиду ограниченных водных ресурсов. Это означает, что в бассейнах рек Кубань, Терек и Сулак не следует ожидать значительного роста площадей орошаемых земель и, следовательно, изменение объемов водопотребления в этих бассейнах будет связано преимущественно с показателями фактически поливаемых земель.

При такой схеме расширения орошаемых земель на юге России возможны риски возникновения дефицита воды в бассейнах рек Дона и Кубани, особенно на территории Белгородской, Курской и Тамбовской областей и Краснодарского края, которые в настоящее время имеют ограниченные водные ресурсы.

Для всех остальных рек рост сельскохозяйственного водопотребления не приведет к появлению проблем в использовании водных ресурсов.

При любом развитии экономики - инерционном или прогрессивном климатические изменения не окажут влияния на структуру суммарного водопотребления по двум причинам. Первая - в планах экономического развития страны изначально заложена предпосылка достижения прежних показателей в экономике при сокращении удельного расхода воды за счет внедрения новых технологий производства и схем водоснабжения в промышленности и сельском хозяйстве.

Вторая причина - относительно стабильный объем коммунального водопотребления за многолетний период (1980-2015 гг.) и прогнозируемая очень мало меняющаяся по сравнению с настоящим временем численность населения. При условии роста уровня жизни населения и, следовательно, увеличения норм водопотребления на человека, коммунальное водопотребление изменится незначительно за счет модернизированных систем водоснабжения и водоотведения, которые снизят потери воды при транспортировке, а установка приборов учета будет стимулировать экономию расхода воды в коммунальном хозяйстве. При этом сохранится практически постоянное за многолетний период соотношение объемов промышленного, сельскохозяйственного и коммунального водопотребления, соответственно 66,14 и $20 \%{ }^{130}$

\section{Водообеспеченность}

В настоящее время на ЕЧР водообеспеченность населения находится В пределах 0,1 $\div 16$ тыс. мчел., т. е. от катастрофически низкой (на некоторых участках р. Северский Донец) до высокой (бассейны рек Невы, Нарвы, Западной Двины и ряд участков р. Волги).

На юге ЕЧР водообеспеченность всех речных водосборов является низкой и составляет в целом для Дона - 2,5, Кубани - около 4,0, Терека - 4,5, Сунжи - 1,8 тыс. м $^{3} /$ чел.

\footnotetext{
${ }^{130}$ Водные ресурсы России и их использование. 2008. СПб. 598 с.
} 
Серьезные проблемы водообеспечения имеют место и в достаточно увлажненных регионах, имеющих развитую экономику и высокую плотность населения - бассейны рек Волги, Оки, Клязьмы, Суры и Урала.

В маловодные годы все перечисленные водосборы, естественно, имеют еще более низкую водообеспеченность, а такие водохозяйственные участки как р. Дон - Цимлянская ГЭС, ст-ца Раздорская, р. Кубань - устье, р. Сунжа г. Грозный, р. Ока - города Муром и Горбатов, р. Клязьма - г. Владимир, р. Урал - г. Верхнеуральск, переходят в категорию катастрофически низкой водообеспеченности - менее 1 тыс. мัчел. в год

Важно отметить, что территории этих бассейнов, имеющие острые проблемы водообеспечения, особенно в маловодные годы, являются наиболее густонаселенными и экономически развитыми регионами нашей страны; общая площадь этих регионов составляет 14,7 \% территории России.

Водообеспеченность водосборов северных и сибирских рек очень высока. Значения реальной водообеспеченности находятся в пределах от 80 тыс. м³/чел. (Северная Двина - устье) до 1350 тыс. м³/чел. (р. Камчатка с. Долиновка). Исключение составляют бассейны, ограниченные створами р. Обь - г. Колпашево, р. Томь - г. Томск, р. Иртыш - г. Омск, где водообеспеченность определяется на границе средней и высокой (более 10 тыс. м $^{3} /$ чел в год).

Представленная неравномерная по территории России ситуация с водообеспеченностью показывает очень высокую вероятность климатообусловленных рисков, связанных с дальнейшим снижением водообеспеченности в тех субъектах Российской Федерации, в которых и в настоящее время имеются проблемы дефицита воды. Это прежде всего субъекты, входящие в бассейны рек Дона, Кубани, частично рек Волги и Урала - Белгородская, Брянская, Воронежская, Курская, Липецкая, Ростовская, Московская (с городом Москвой), Орловская, Тамбовская, Тульская, Оренбургская, Пензенская, Курганская, Свердловская, Челябинская области, Краснодарский и Ставропольский края, Республики Калмыкия, Дагестан, Ингушетия, Кабардино-Балкария, Чеченская, Башкортостан и Мордовия, Крымский фредеральный округ. Эти субъекты составляют перечень территорий с низкой водообеспеченностью, рассчитанной на уровень 2015 года с учетом средних многолетних суммарных (местный сток и приток) водных ресурсов.

Оценки возможных изменений речного стока, полученные по ансамблю из 24 моделей для умеренного сценария потепления глобального климата ${ }^{131}$, позволяют определить регионы с высокой степенью климатообусловленных рисков. В соответствии с выполненными прогнозными оценками дефици воды ожидается в бассейнах Дона и Кубани. Водообеспеченность в пределах этих бассейнов составляет не более 1,0 тыс. ${ }^{3}$ на человека. Такая водообеспеченность оценивается как катастрофически низкая. Учитывая прогнозные изменения стока в этих бассейнах, водообеспеченность может

\footnotetext{
${ }^{131}$ Георгиевский В. Ю. (2015). Водные ресурсы рек Российской Федерации / Пленарный доклад. Труды IY Всероссийской научной конференции. М., 15-18 сентября 2015 г.
} 
очень незначительно повыситься до 2-2,5 тыс. м $^{3}$ на человека, т. е. до категории очень низкой водообеспеченности.

Низкая водообеспеченность прогнозируется в бассейнах Терека, Средней и Нижней Волги, а также р. Урал. Крайне острая ситуация будет наблюдаться в пределах участка р. Волги - Чебоксарский гидроузел, где водообеспеченность при прогнозных вариантах приближается к водообеспеченности в маловодные годы.

В бассейнах рек Кама, Белая и Иртыш прогнозируется средняя водообеспеченность, за исключением верхнего течения Иртыша, где при прогнозируемом незначительном понижении водных ресурсов следует ожидать обострения проблем водообеспеченности, особенно в маловодные периоды.

На остальных реках Сибири и Дальнего Востока развитие промышленности и сельского хозяйства не ограничено водопотреблением, и водообеспеченность на несколько порядков выше, чем на территории основных рек ЕЧР.

\section{Опасные гидрологические явления}

Серьезную озабоченность вызывает наблюдающееся в последние десятилетия увеличение количества опасных гидрологических явлений на реках России, наносящих существенный ущерб населению и отраслям экономики. Особую опасность представляют дождевые паводки, интенсивность и повторяемость которых в ряде регионов (Северный Кавказ, Дальневосточное Приморье) увеличивается.

Во время катастрофического летнего паводка 2013 г. в бассейне Амура на многих водомерных постах уровни и расходы воды намного превысили наблюдавшиеся ранее максимумы за весь период наблюдений (по статистике такая ситуация повторяется на Нижнем Амуре один раз в 200-250 лет), а ущерб экономики страны составил 527 млрд руб.

На реках Черноморского побережья Кавказа и бассейна Кубани в последние десятилетия также прошли катастрофические паводки, сформировавшиеся в результате выпадения экстремальных осадков, при которых максимальные расходы воды, значительно превысили ранее наблюденные. Для рек этого региона характерным является значительное увеличение изменчивости максимальных расходов воды.

Большое значение для предотвращения вероятных рисков имеет оценка возможных изменений максимальных расходов воды редкой повторяемости в бассейнах рек, где расположены крупные водохранилища. Специалистами Росгидромета выполнена детальная региональная оценка возможных изменений характеристик водного режима основных рек Российской Федерации до 2050 года и фракторов, их определяющих. ${ }^{132}$ Результаты моделирования показывают, что наряду с увеличением годового притока к водохранилищам, расположенным на северо-востоке и Дальнем Востоке страны, и их

\footnotetext{
${ }^{132}$ Shkolnik I., Pavlova T., Efimov S., et al. Future changes in peak river flows across northern Eurasia as inferred from an ensemble of regional climate projections under the IPCC RCP8.5 scenario. - Climate Dynamics, 2017; doi: 10.1007/s00382-017-3600-6.
} 
гидроэнергетического потенциала здесь следует ожидать существенного увеличения максимальных расходов приточности с потенциальной угрозой опасности для гидротехнических сооружений. В бассейнах этих водохранилищ увеличатся риски опасных наводнений.

В перспективе к середине XXI в. экстремальность осадков в летний период в горных районах Кавказа, в Сибири и на Дальнем Востоке может увеличиться, что приведет к увеличению частоты и высоты дождевых и снегодождевых паводков.

Необходимо отметить, что в результате наблюдающегося увеличения межгодовой изменчивости стока, особенно сезонного, возможны как аномально многоводные, так и аномально маловодные годы и сезоны. Материальный ущерб от маловодий иногда сопоставим с ущербом от наводнений, так как они осложняют работу водозаборов, нарушают водоснабжение населенных пунктов и предприятий, уменьшают выработку гидроэлектроэнергии, затрудняют речное судоходство, ухудшают качество воды.

\section{5 Лесное хозяйство}

Лес как один из основных природных ресурсов, наряду с земельными, водными, минерально-сырьевыми, является национальным богатством государства. Леса, расположенные на территории Российской Федерации, представляют собой один из важнейших возобновляемых природных ресурсов, составляя более четверти мировых запасов древесной биомассы. В 2015 г. лесные площади и земли под лесными насаждениями занимали 897,0 млн га. Основная доля лесообразующих пород приходится на ценные хвойные: сосна, ель, лиственница, кедр.

Лесной комплекс России исторически занимает важное место в структуре экономики страны. В настоящее время он находится на седьмом месте по объемам производимой продукции и на четвертом - по объемам экспорта товаров после экспорта газа, нефти, черных и цветных металлов.

На функционирование лесного комплекса оказывают влияние антропогенные и природные факторы. В значительной мере «здоровье» и эволюция лесных экосистем определяется состоянием климата. От климатических условий зависит производительность лесов и разнообразие лесной фрлоры и фауны; направленность и динамика нежелательных сукцессий ${ }^{133}$; гидрологический режим лесов и рек; устойчивость лесных биогеоценозов ${ }^{134}$ к разрушающим природным и антропогенным факторам.

\footnotetext{
${ }^{133}$ Сукцессия - последовательная необратимая смена биоценозов, преемственно возникающих на одной и той же территории в результате влияния природных факторов (в том числе внутренних сил) или воздействия человека. Биоценоз - это исторически сложившаяся совокупность животных, растений, грибов и микроорганизмов, населяющих относительно однородное жизненное пространство (определенный участок суши или акватории) и связанных между собой окружающей их средой.

134 Биогеоцено́з - система, включающая сообщество живых организмов и тесно связанную с ним совокупность абиотических факторов среды в пределах одной территории, связанные между собой круговоротом веществ и потоком энергии (природная экосистема).
} 
Наиболее значимыми для лесного хозяйства климатическими показателями являются ${ }^{135}$ :

- радиационный баланс;

- количество твердых и жидких осадков;

- сумма активных температур;

- продолжительность вегетации, т. е. периода с температурой выше $+10^{\circ} \mathrm{C}$;

- индекс континентальности (функция широты, годовой и суточной амплитуды температуры воздуха, дефицита влажности в самый сухой месяц);

- число дней с сильным ветром;

- индексы пожароопасности, отражающие баланс иссушающих и увлажняющих фракторов для лесных экосистем;

- число дней с низкой температурой воздуха (ниже $-30^{\circ} \mathrm{C}$ ).

Постепенное увеличение средних многолетних значений первых четырех показателей в целом положительно влияет на лесные ресурсы умеренного климатического пояса. Однако понятно, что для каждого растения существует свой диапазон оптимальных величин этих показателей. Границы распространения древесных пород определяются крайними значениями количества тепла и влаги, а их оптимальные величины обусловливают высокое качество и продуктивность древостоев. Достаточные тепло- и влагообеспеченность для растений одинаково важны. При этом в зависимости от климатических условий лимитирующим фрактором может быть лишь один из них. Так, в пределах северной и средней тайги рост древесных пород определяется недостатком тепла при избытке влаги. В зоне лесостепи достаточно тепла, но не хватает влаги, а для зоны смешанных лесов характерно достаточное количество и тепла и влаги. Влияние на древостой любого климатического фактора происходит в комплексе с другими факторами и оценивается определенными показателями. В России, как и во всем мире, наибольшее хозяйственно-экономическое значение имеют хвойные леса. Поэтому при оценке пригодности конкретных регионов для лесного хозяйства по параметрам климата обычно ориентируются на некоторые оптимальные значения, характерные для зон, продуктивность естественных хвойных насаждений в которых максимальна. Примерами комплексных показателей, отражающих соотношение тепла и влаги, являются радиационный индекс сухости Будыко ${ }^{136}$ и коэффрициент увлажнения Высоцкого-Иванова. ${ }^{137}$

\footnotetext{
135 Энциклопедия климатических ресурсов Российской Федерации. Под ред. Н. В. Кобышевой. СПб: Гидрометеоиздат. 2005. 319 с.

136 Радиационный индекс сухости Будыко - отношение годового радиационного баланса земной поверхности к сумме теплоты, необходимой для испарения годовой суммы осадков на анализируемой территории. Данный индекс служит основой для дифференциации географических зон. При значениях индекса менее единицы климат рассматривается как влажный, от единицы до трех - недостаточно влажный, более трех - сухой.
} 
Оптимальные или близкие к ним значения указанных индексов наблюдаются в зонах южной тайги и смешанных лесов.

Возрастание значений последних четырех из вышеперечисленных показателей, характеризующих интенсивность неблагоприятных и опасных климатических условий, увеличивает риски для воспроизводства лесных ресурсов.

Наблюдаемые и ожидаемые в будущем климатические изменения влияют на величину всех этих показателей, а значит, вероятно, и на условия воспроизводства леса, очень сложным и неоднозначным образом. Некоторые изменения климата могут оказывать непосредственное воздействие на лесные экосистемы. Например, более теплый климат вызывает удлинение периода вегетации у древесных растений, что при достаточном увлажнении способствует увеличению их продуктивности и накоплению биомассы. Следовательно, существует теоретическая возможность перемещения некоторых растительных зон в северном направлении, а также вверх по склонам гор. Однако климатические изменения, способствующие увеличению продуктивности древесных растений, могут одновременно иметь побочные эффректы, например, в виде уменьшения биоразнообразия лесных экосистем.

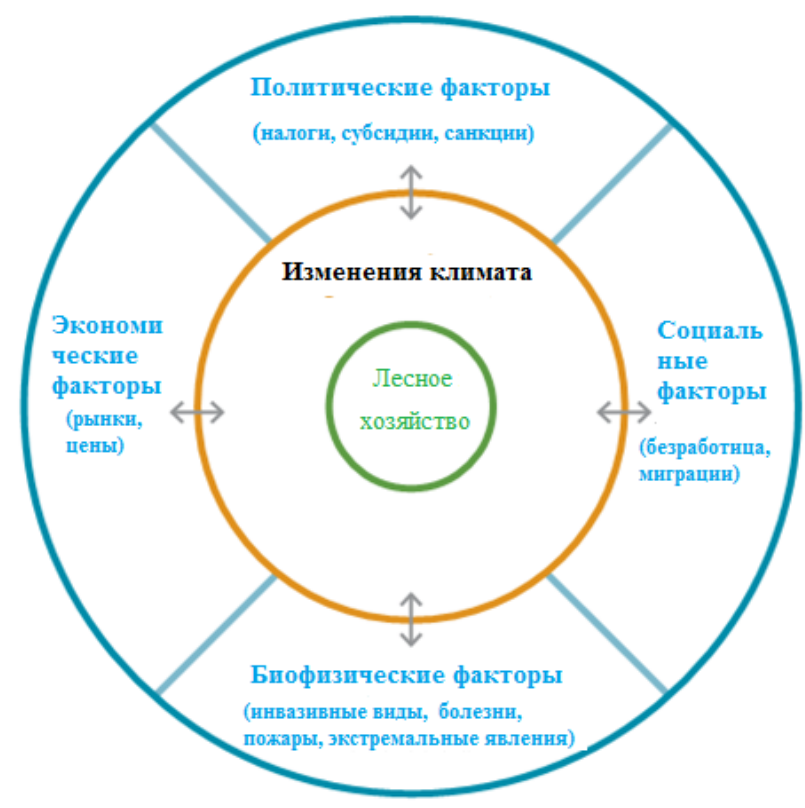

Рис. 3.13 Комплекс природных и социально-экономических последствий изменения климата для лесного хозяйства.

Другие эффректы представляют собой косвенные последствия изменения климатических условий (повторяемости и интенсивности лесных пожаров, экстремальных погодных явлений, распространения болезней и вредителей леса) или зависят от экономических и социальных факторов, связанных с изменением климата, таких как безработица, миграция населения, изменения

\footnotetext{
${ }^{137}$ Коэффициент увлажнения Высоцкого-Иванова - отношение суммы осадков за месяц (год) к месячной (годовой) испаряемости. Если коэффициент увлажнения около единицы - увлажнение достаточное, менее единицы - недостаточное, более единицы - избыточное.
} 
на рынках (например, увеличение спроса на биотопливо, призванного в ряде регионов постепенно заменить ископаемое топливо).

Комплекс природных и социально-экономических последствий изменения климата для лесного хозяйства схематически представлен на рис. $3.13 .{ }^{138}$

Таблица 3.7 Площадь погибших лесных насаждений ${ }^{*}$ (тыс. га/год) ${ }^{139}$

\begin{tabular}{|c|c|c|c|c|c|c|c|}
\hline $\begin{array}{c}\text { Причины гибели лесных } \\
\text { насаждений }\end{array}$ & 2000 & 2005 & 2010 & 2011 & 2012 & 2013 & $2014^{* *}$ \\
\hline ВСЕГО & 777,5 & 988,2 & 804,9 & 418,6 & 378,7 & 624,4 & 511,6 \\
\hline $\begin{array}{l}\text { в том числе: } \\
\text { от лесных пожаров } \\
\text { от воздействия }\end{array}$ & 709,7 & 465,5 & 625,6 & 250,4 & 243,0 & 503,0 & 380,5 \\
\hline $\begin{array}{l}\text { неблагоприятных погодных } \\
\text { условий }\end{array}$ & 38,2 & 461,9 & 126,7 & 101,7 & 69,3 & 38,7 & 44,1 \\
\hline от антропогенных факторов & 2,0 & 5,3 & 16,1 & 3,1 & 3,9 & 3,5 & 5,5 \\
\hline $\begin{array}{l}\text { от воздействия вредных } \\
\text { организмов - всего } \\
\text { в том числе: }\end{array}$ & 27,7 & 55,5 & 36,4 & 63,3 & 62,4 & 79,2 & 81,5 \\
\hline $\begin{array}{l}\text { от повреждения вредными } \\
\text { насекомыми }\end{array}$ & 20,5 & 33,6 & 9,3 & 30,5 & 30,7 & 42,5 & 44,5 \\
\hline $\begin{array}{l}\text { от повреждения дикими } \\
\text { животными }\end{array}$ & 1,5 & 0,3 & 0,2 & 0,1 & 0,0 & 0,2 & 0,1 \\
\hline $\begin{array}{l}\text { от иных групп вредных } \\
\text { организмов }\end{array}$ & 5,8 & 21,6 & 26,9 & 32,8 & 31,6 & 36,5 & 36,9 \\
\hline $\begin{array}{l}\text { из них погибло хвойных лесных } \\
\text { насаждений - всего } \\
\text { в том числе: }\end{array}$ & 345,6 & 953,4 & 609,1 & 330,7 & 299,2 & 571,4 & 468,8 \\
\hline $\begin{array}{l}\text { от лесных пожаров } \\
\text { от воздействия }\end{array}$ & 290,7 & 445,8 & 474,0 & 197,2 & 195,5 & 469,8 & 356,6 \\
\hline $\begin{array}{l}\text { неблагоприятных погодных } \\
\text { условий }\end{array}$ & 27,9 & 452,1 & 87,2 & 74,3 & 51,3 & 28,6 & 31,4 \\
\hline от антропогенных фракторов & 1,6 & 4,7 & 16,1 & 3,0 & 3,8 & 3,4 & 5,4 \\
\hline $\begin{array}{l}\text { от воздействия вредных } \\
\text { организмов - всего } \\
\text { в том числе: }\end{array}$ & 25,4 & 50,8 & 31,7 & 56,2 & 48,5 & 69,7 & 75,4 \\
\hline $\begin{array}{l}\text { от повреждения вредными } \\
\text { насекомыми }\end{array}$ & 20,4 & 33,5 & 8,9 & 30,3 & 29,9 & 41,8 & 44,4 \\
\hline $\begin{array}{l}\text { от повреждения дикими } \\
\text { животными }\end{array}$ & 1,0 & 0,2 & 0,2 & 0,0 & 0,0 & 0,2 & 0,1 \\
\hline $\begin{array}{l}\text { от иных групп вредных } \\
\text { организмов }\end{array}$ & 4,1 & 17,2 & 22,6 & 25,8 & 18,5 & 27,7 & 30,9 \\
\hline
\end{tabular}

* С 2012 г. - включая оценки индивидуальных предпринимателей.

* На момент завершения подготовки настоящего доклада официальные данные, представленные на сайте Росстата, заканчивались 2014 г.

*** К антропогенным фракторам здесь относятся рубки главного пользования, аэротехногенное загрязнение, воздействие АЭС и других радиационных объектов, строительная и горнопромышленная деятельность, использование минеральных удобрений и пестицидов, гидротехнические сооружения, рекреационная нагрузка, степень совершенства нормативноправовой базы. Частично сюда относятся и пожары.

${ }^{138}$ Food and Agriculture Organization of the United Nations, 2013: Climate change guidelines for forest managers. FAO Forestry Paper № 172, Rome, 110 p.

${ }_{139}$ По данным Росстата: http://www.gks.ru/bgd/regl/b15_38/Main.htm. 
В настоящее время наиболее значимые погодно-климатические риски для лесного хозяйства обусловлены лесными пожарами, воздействием экстремальных погодных явлений, вредителей и болезней леса. Важными факторами, влияющими на состояние лесных экосистем, являются также возможные сдвиги природных зон и уменьшение биоразнообразия.

В период с 2000 по 2014 гг. в России ежегодно погибало в среднем около 600 тыс. га лесных насаждений (табл. 3.7). Из них на 70 \% площади леса погибли из-за пожаров, на 20 \% из-за экстремальных условий погоды (ураганного ветра, ледяного дождя и т. д.), на $10 \%$ - из-за воздействия вредных насекомых и болезней. Однако эти соотношения значительно варьируют от года к году в зависимости от погодных условий.

\section{Утрата биоразнообразия и сдвиг природных зон}

За последние десятилетия изменения в состоянии растительности в мире наблюдались на всех уровнях ее организации. На 5-10 \% увеличилась глобальная относительная скорость фотосинтеза в результате увеличения содержания $\mathrm{CO}_{2}$ в атмосфере. Зарегистрировано удлинение вегетационного периода в среднем на 0,029 сут. в год для Северного полушария и на 0,04 сут. в год для Евразии. Первичная продуктивность растений в 1982-2000 гг. в Северной Евразии увеличивалась со скоростью $1,17 \%$ в год ${ }^{140}$.

По мнению ряда исследователей изменение климата одновременно влечет опасность значительной утраты биоразнообразия, циклов воспроизводства животных и растений и/или миграции животных, продолжительности вегетационного периода, распределения видов и размеров популяций и даже вымирания видов во многих лесных районах по причине приближения к тепловой границе пригодной области распространения. ${ }^{141}$ Это касается вытеснения одних древесных пород другими, зачастую менее ценными, снижение чистой продуктивности экосистем и биомов, доминирование «сорняковых» видов.

Вследствие климатических изменений зоны распространения многих видов передвинутся с прежних мест в северном направлении или вверх на возвышенности. Скорость изменения существующих лесных экосистем и замена их на новые сообщества растений и животных будет зависеть от частоты, интенсивности, масштабов распространения и районов нарушений, вызванных климатическими и неклиматическими причинами.

Согласно оценкам ${ }^{142}$ из всех лесных регионов планеты наибольшие изменения будут происходить в бореальных и умеренных районах Евразии и Северной Америки. Ожидается, что климатические зоны будут смещаться со

\footnotetext{
${ }^{140}$ Росгидромет, 2014.

${ }^{141}$ Королева Т.С., Константинов А.В., Шунькина Е.А.. Угрозы и социально-экономические последствия изменения климата для лесного сектора. Труды Санкт-Петербургского научно-исследовательского института лесного хозяйства, № 3, 2015, с. 55-71.

${ }^{142}$ МГЭИК, 2014a.
} 
скоростью 5 км в год, в результате чего бореальные леса займут новые территории на севере, но исчезнут или будут вытеснены на южных своих границах. Для России процессы трансформации растительных сообществ начнутся на 70 \% площадей сосняков и 50 \% - ельников. Менее чувствительны к потеплению смешанные леса и дубравы (трансформации стартуют на $20 \%$ площади), а самыми устойчивыми, вероятно, будут лиственничные леса Восточной Сибири (5 \% трансформаций). По прогнозам МГЭИК, к 2100 г. могут исчезнуть 30 \% сосновых и еловых лесов. Сокращения сроков холодного времени года, повышение температуры воздуха и рост воздействия пожаров могут привести к деградации многолетней мерзлоты, что обусловит трансформацию лесных почв и создаст лесорастительные условия, которые не имеют пока аналогов. При этом на повышениях возникнут засушливые условия, которые будут препятствовать как развитию там мхов, так и подроста ели. Увеличится глубина сезонного протаивания, в среднем на 20-30 \%, а в отдельных районах Западной Сибири - до 50 \%.

Представленные оценки согласуются с уже выявленными изменениями границ природных зон в различных регионах России. Так, в бассейне р. Хатанги (Таймыр) за последние 45 лет произошло увеличение сомкнутости лиственничников и их продвижение в тундру со скоростью 3-10 м/год. ${ }^{143}$ На Полярном Урале в этот период происходило интенсивное расселение древесной и кустарниковой растительности в горные тундры, в результате чего зафиксированы поднятие верхней границы леса и увеличение степени облесенности территорий. Увеличились густота, сомкнутость и продуктивность древостоев. Обзор данных показывает, что расширение лесной растительности в зонах ее экотона ${ }^{144}$ с тундрой имело панконтинентальный характер. Это явление наблюдается как в горах, так и на равнинах Северной Евразии. Сопоставление фотографрий начала XX в. с современными показывает, что на многих ныне облесенных участках ранее преобладали тундровые экосистемы. Однако распространение леса в южной части зоны тундры может замедлиться вследствие неблагоприятного воздействия сильных ветров в этом регионе. ${ }^{145}$

\section{$\underline{\text { Лесные пожары }}$}

По данным Федеральной службы государственной статистики (Росстат), ежегодно в России регистрируется от 10 тыс. до 35 тыс. лесных пожаров, охватывающих площади от 500 тыс. до 2,500 млн га. Всего с начала 1992 и до конца 2014 г. В России произошло 589768 лесных пожаров. По данным Федерального агентства лесного хозяйства, в среднем размер ущерба от лесных пожаров в год составляет около 20 млрд руб., из них от 3 до 7 млрд ущерб лесному хозяйству (потери древесины). Обычно возгорания лесов в

\footnotetext{
143 Болотов И.Н., Сурсо М.В., Филиппов Б.Ю., Гофаров М.Ю., Тараканов А.М., 2012: Изменения древостоев в изолированных лесных островах на востоке Большеземельской тундры за последние 100 лет в условиях меняющегося климата, Лесной журнал, № 5 с. 30-37.

144 Зона резкого перехода между биомами.

145 Олсон Р., 2011: Бореальные леса и изменение климата, Устойчивое лесопользование, № 3(28), c. $27-38$.
} 
России начинаются в апреле и длятся до октября. Возникновение и развитие лесных пожаров возможно только при длительной сухой погоде, но возгорание происходит в более чем 90 \% случаев по вине человека.

Одним из потенциальных долговременных последствий лесных пожаров является образование более гомогенных лесных ландшафтов, где доминируют лиственные породы. Так, в средних по увлажнению условиях около 40 \% сосновых гарей восстанавливается березой и осиной. ${ }^{146}$ Причина гибели деревьев - не только воздействие высоких температур, но и последующее заселение их вредителями. Изменение климата и условий произрастания может сделать невозможным возвращение растительности в исходное состояние. Риск возникновения лесных пожаров также усиливается из-за неконтролируемого расширения сельскохозяйственных угодий за счет покрытых лесом участков земли и в результате увеличения длительности сезона активного использования лесов в рекреационных и туристических целях.

На характер и степень повреждения древостоя пожарами влияет ряд факторов: вид пожара, тип леса, породный состав, возраст, полнота насаждения, крутизна склона, погодные условия и т. д.

В соответствии с оценками МГЭИК ${ }^{147}$, в отдельных регионах Евразии, главным образом на юге, риск пожароопасности к середине XXI в. может увеличиться троекратно по сравнению с концом XX в. Наряду с ростом среднего летнего уровня пожароопасности проявляется увеличение длительности пожароопасного периода с тенденцией смещения пика пожароопасности к середине лета.

Определяющим фрактором риска пожароопасности наряду с ростом температуры является изменение режима увлажнения. В частности, из-за сокращения интенсивных осадков к середине XXI в. прогнозируется сильное увеличение индекса пожароопасности Нестерова ${ }^{148}$ на юго-востоке и в центре АЧР. ${ }^{149}$ В условиях агрессивного сценария (RCP8.5) антропогенного воздействия на климатическую систему на всей ЕЧР, в Западной и частично в Восточной Сибири к концу XXI в. ожидается увеличение пожароопасного периода на 10-30 суток, а на некоторых участках - и на 50 суток. $^{150}$ При умеренном сценарии (RCP4.5) воздействия на климат в тех же регионах ожидается увеличение пожароопасного периода на 10-20 суток.

\footnotetext{
146 Иванова Г.А., Конрад С., Макрае Д.Д. и др., 2014: Воздействие пожаров на компоненты экосистемы среднетаежных сосняков Сибири. Новосибирск. Наука, 229 с.

${ }_{147}^{14}$ МГЭИК, 2014а.

148 Комплексный показатель пожарной опасности Нестерова $($ КПО увлажняющих факторов соотношением: $K П O_{H}=\Sigma_{n}\left(T-T_{d}\right) \times T_{d}$, где $\mathrm{T}-$ температура воздуха в 12 часов, $\mathrm{T}_{\mathrm{d}}-$ точки росы в 12 часов, $\mathrm{n}$ - число дней после последнего дождя. За факт выпадения осадков принимаются любые значения, начиная с 3 мм за 24 ч. Данный показатель пожарной опасности может изменяться от одного до нескольких тысяч градусов, а в периоды устойчивой сухой и жаркой погоды превышать 10000 . Для характеристики степени пожарной опасности весь диапазон значений делится на пять интервалов классов.

149 Катцов В.М., Мелешко В.П., Надежина Е.Д., Павлова Т.В., Школьник И.М., 2011: Оценка климатических воздействий на природные системы России в середине XXI века, Проблемы экологического мониторинга и моделирования экосистем, т. 24. с. 271-294.

${ }^{150}$ Росгидромет, 2014.
} 


\section{Экстремальные погодные явления}

В настоящее время погодно-климатические риски для лесного хозяйства в значительной мере обусловлены изменением частоты и интенсивности неблагоприятных и опасных погодных явлений. К ним относятся аномально высокие и низкие температуры воздуха и почвы, экстремальные суточные и годовые амплитуды температуры, засухи, ураганные ветры, вызывающие массовый ветровал и бурелом, ливни, во время которых происходит либо смыв отдельных участков леса, либо усыхание деревьев в результате длительного затопления, а также сильные снегопады, град, поздние весенние заморозки и др. Массовое повреждение деревьев, их ослабление и частичная гибель могут вызываться и обильно выпавшим мокрым снегом (снеголом) или обледенением.

Последствия таких явлений для лесных экосистем носят комплексный и долговременный характер. ${ }^{151}$ Так, последствия ветровалов не сводятся только к потере товарной древесины. Массовый ветровал обусловливает нарушения всей лесной экосистемы (почвенного покрова, древостоя, всех ярусов растительности, фрауны и т. д.), а для их устранения требуются десятилетия.

Воздействие экстремальных погодных явлений может значительно ослабить древостой и уменьшить его сопротивляемость вредителям и болезням. Так, например, морозобоины и ожоги коры могут явиться причиной развития инфекционных некрозов и раковых заболеваний стволов, или из-за механических повреждений в рану может попасть возбудитель инфекционной болезни. ${ }^{152}$ Таким образом, воздействие вредных насекомых и болезней на лес в значительной мере провоцируется экстремальными погодными условиями.

Особенно губительны опасные и неблагоприятные погодные явления для молодых и гомогенных лесов. Однако, по мнению некоторых исследователей, в девственных первобытных лесах ветровалы и пожары могут играть позитивную роль омолаживающего фрактора. При этом структура таких лесов столетиями остается разнообразной и стабильной.

\section{Болезни и вредители леса}

Анализ динамики санитарного состояния лесов свидетельствует о росте ущерба от вредителей и болезней, а также об ухудшении состояния насаждений в 1996-2000 гг. ${ }^{153}$, которое продолжалось и в начале XXI в. В целом по России за последние 20 лет $\mathrm{XX}$ века ежегодно регистрируемая площадь очагов вредителей и болезней увеличилась в 2,2 раза по сравнению со средней многолетней (3 млн га). Вспышки численности вредителей часто связаны с тем, что при высоких летних температурах насекомые успевают

\footnotetext{
151 Королева Т.С., Константинов А.В., Шунькина Е.А., 2015: Угрозы и социально-экономические последствия изменения климата для лесного сектора. Tруды Санкт-Петербургского научноисследовательского института лесного хозяйства, № 3, с. 55-71.

152 Росгидромет, 2014.

153 Лямцев Н.И., 2004: Статистическая информация по защите леса в Европейской России и методы ее анализа, Лесохозяйственная информащчи, № 12, с. 6-18.
} 
пройти полный жизненный цикл за один год, а не за два, как при обычных погодных условиях.

Процесс изменения санитарного состояния лесов имеет и колебательный характер. Период колебаний составляет около 22-25 лет и характеризует периодичность возникновения очагов вредных организмов на больших площадях, т. е. пандемических вспышек массового размножения. Такие очаги были в 1976-1978 и в 2000-2003 гг. (табл. 3.8).

Таблица 3.8 Площадь очагов вредных организмов в лесах ${ }^{*} 154$ (на конец года; тыс. га)

\begin{tabular}{l|c|c|c|c|c|c|c}
\hline $\begin{array}{l}\text { Площадь, пораженная } \\
\text { вредными организмами }\end{array}$ & 2000 & 2005 & 2010 & 2011 & 2012 & 2013 & $2014^{* *}$ \\
\hline ВСЕГО & $\mathbf{8 5 4 9 , 7}$ & $\mathbf{5 1 4 2 , 6}$ & $\mathbf{3 9 1 0 , 8}$ & $\mathbf{2 5 0 2 , 6}$ & $\mathbf{2 6 2 0 , 6}$ & $\mathbf{3 3 1 0 , 5}$ & $\mathbf{4 1 3 7 , 5}$ \\
в том числе: & & & & & & & \\
хвоегрызущими & 6542,2 & 353,3 & 348,0 & 335,9 & 371,0 & 453,5 & 489,2 \\
листогрызущими & 708,3 & 1325,9 & 689,7 & 664,2 & 722,8 & 1347,1 & 2234,2 \\
иными группами вредных & 1299,2 & 3463,4 & 2873,1 & 1502,5 & 1526,9 & 1509,9 & 1414,2 \\
организмов & & & & &
\end{tabular}

* С 2012 г. - включая оценки индивидуальных предпринимателей.

* На момент завершения подготовки настоящего доклада официальные данные, представленные на сайте Росстата, заканчивались 2014 г.

Ежегодная площадь насаждений, погибших от вредителей и болезней, в среднем составляет от 5 до 15 \% (табл. 3.7) общей площади погибших лесов. Большая часть погибших древостоев (88 \%) находится в Сибири и на Дальнем Востоке и представлена преимущественно хвойными лесами. Максимальная интенсивность усыхания лесов, рассчитанная как отношение площади погибших лесов к покрытой лесом площади, зафиксирована в Южном федеральном округе и лесах Республики Калмыкия. Высокие показатели интенсивности усыхания отмечены в Архангельской, Московской, Читинской областях, Чукотском АО и Приморском крае.

В условиях более теплого климата ожидается увеличение частоты и интенсивности вспышек численности насекомых. ${ }^{155}$ Очевидно, потепление способствует появлению новых и аномальному распространению традиционных вредителей и микроорганизмов, появлению чужеродных видов в регионах, где они раньше не встречались. К существенному увеличению интенсивности поражения лесов вредителями приводит совокупное действие трех фракторов: рост климатической приспособляемости вредоносных видов, перемещение вредителей на новые места обитания, в том числе вследствие расширения торговли лесом, и способность вредителей адаптироваться благодаря широкому выбору деревьев-носителей. Помимо усиления этих факторов риска, тяжесть последствий от появления новых вредителей усугубляет то обстоятельство, что интродуцированные вредители зачастую

\footnotetext{
${ }^{154}$ По данным Росстата: http://www.gks.ru/bgd/regl/b15_38/Main.htm.

155 Олсон Р., 2011: Бореальные леса и изменение климата, Устойчивое лесопользование, № 3(28), c. $27-38$.
} 
приживаются там, где отсутствует обычный набор естественных врагов, сдерживающих их распространение. При этом под угрозу попадает генетическое разнообразие лесной популяции фрлоры и фауны.

Изменение климата также может сказаться на увеличении численности насекомых, питающихся древесной растительностью, через нарушение связи паразит-хозяин. Исследования показывают ослабление связи хозяин-паразит при потеплении климата, вызванное тем, что при изменении сроков прохождения насекомым-хозяином жизненного цикла, паразитам сложнее находить особи хозяина. Учитывая важную роль паразитов в регулировании численности насекомых, питающихся древесной растительностью, и в малонарушенных, и в управляемых экосистемах при изменении климата следует ожидать более частых и более интенсивных вспышек численности насекомых, питающихся растительностью.

В настоящее время предположение о том, что наиболее общими причинами массовой гибели лесов являются климатические изменения глобального характера, является практически безальтернативной гипотезой.

Резюмируя вышеизложенное, следует подчеркнуть, что, по мнению большинства исследователей, климатические изменения оказывают неоднозначное воздействие на лесные ресурсы России. С одной стороны, повышение средних многолетних температур создает предпосылки для расширения ареалов древесной растительности в северных и северовосточных регионах страны. Однако долговременное постепенное потепление, хотя и является одним из факторов, теоретически влияющих на продуктивность древостоев, не проявляется повсеместно в оценках продуктивности, построенных на данных измерений. Слабый сигнал часто не выделяется на фоне значительной межгодовой изменчивости. Негативные последствия изменения и изменчивости климата для лесного хозяйства проявляются в периодической эскалации вредителей и болезней леса, увеличении числа и площадей лесных пожаров, возрастании интенсивности и частоты погодных аномалий. Согласно оценкам климатических моделей, экстремальность климата в течение XXI в. будет возрастать. Следовательно, вероятно увеличение потерь леса от указанных причин.

Для снижения растущих климатических рисков в лесном хозяйстве Российской Федерации необходимы детальная оценка региональных особенностей изменения климата и лесных экосистем в различных природных зонах, усовершенствованные методы и технологии регионального прогноза климатических условий, а также эффективная и своевременная ликвидация очагов пожаров, болезней и вредных насекомых (в связи с последними особое внимание следует уделить разработке и внедрению биологических методов борьбы).

Для устойчивого развития лесного сектора следует выполнить тщательный совместный анализ как природных, так и антропогенных факторов, влияющих на его эффрективность. Как показывает практика, в большинстве случаев эти фракторы действуют не изолированно, а в виде определенных 
взаимосвязанных компонентов. При этом действие антропогенных фракторов часто усиливает отрицательное влияние природных. Например, повышенная рекреационная нагрузка на лес создает условия для возникновения лесных пожаров и снижает биологическую устойчивость лесных экосистем к вредителям и болезням. В зонах постоянного действия токсических выбросов постепенно меняется видовой состав растительности и животного мира. Из древесных пород в первую очередь повреждаются и погибают хвойные. Из-за преждевременного отмирания хвои меняется микроклимат в насаждении, что сказывается на изменении видового состава травянистой растительности. Начинают развиваться травы, способствующие размножению полевых мышей, систематически повреждающих лесные культуры и т. д. Токсические выбросы также приводят к нарушению или даже полному прекращению плодоношения у большинства древесных пород, что отрицательно сказывается на видовом составе птиц. Появляются устойчивые к действию токсических выбросов виды вредителей леса. В результате образуются деградированные и биологически неустойчивые лесные экосистемы. Адаптационная способность таких сообществ оказывается недостаточной, чтобы успешно развиваться в условиях климатических изменений.

Значимыми рискообразующими фракторами являются также несовершенство нормативно-правовой базы в лесном секторе после принятия в 2006 г. нового Лесного кодекса, недостаточное финансирование отрасли, и, как следствие, недостаток персонала и высокая степень износа основных средств. Bce эти причины не позволяют в полной мере реализовать возможности лесного хозяйства страны и перейти к устойчивому управлению лесами, обеспечивающему многоцелевое, неистощительное, экономически эффрективное лесопользование с учетом изменяющихся климатических и природных условий.

\section{6 Морская деятельность}

Основными видами морской деятельности являются судоходство, портовые операции, разведка, добыча и транспортировка энергоресурсов и рыболовство, которые являются реципиентами воздействия изменений климата на акваториях морей и побережий Российской Федерации.

\section{Судоходство}

Наиболее существенные климатические риски для судоходства в неарктических морях России связаны со штормовым волнением, ограничением видимости, колебаниями уровня моря в отмелой зоне и ледовыми условиями. Штормовое волнение уменьшает скорость судна, причем степень этого уменьшения зависит от водоизмещения судна. Так, при водоизмещении 15 тыс. тонн волны высотой 2,5 м уменьшают скорость хода приблизительно на $10 \%$, а волны высотой 5 м - на 18 \%. При этом на южных морях России, в частности, на Черном море повторяемость высоты волн свыше 2,5 м не 
превышает в среднем за год 3-5 \%, а на Белом и Японском морях эти повторяемости составляют 5-8 \%. ${ }^{156}$ С учетом повторяемости высоты волн и вызванной ими степени уменьшения скорости судна, риски для судоходства, связанные с потерей ходового времени за счет ветрового волнения в неарктических морях России в настоящее время оцениваются в 0,3-0,5 \%.

Ограничения видимости связаны, преимущественно, с туманом. В этих случаях, особенно в прибрежной зоне и районах интенсивного судоходства, суда вынуждены останавливаться или существенно замедлять ход, что приводит к потери судового времени. Средняя повторяемость туманов (исходя из среднего числа дней в году с туманом) на прибрежных акваториях неарктических морей России весьма различна и колеблется от 2-8 \% для Черного и Азовского морей и 3-6 \% в районе Сахалина до 8-9 \% в южной и до 22 \% в северной части Белого моря. Средняя продолжительность туманов составляет 3-6 часов. ${ }^{157}$

Колебания уровня моря в прибрежной зоне вызваны сгонно-нагонными явлениями, обусловленными сильными продолжительными ветрами. Для судоходства наиболее опасны сгонные явления в отмелой зоне, когда уровень моря может в течение нескольких часов уменьшиться на величину от несколько десятков сантиметров до 1,0-1,5 м, что, в свою очередь, способно привести к невозможности прохода судов по морским каналам.

\section{Портовые операции}

При погрузочно-разгрузочных работах ограничения накладываются на скорость ветра, воздействующую на портовые краны и переносимые ими грузы. Средняя повторяемость сильных ветров (более $15 \mathrm{~m} / \mathrm{c}$ ) колеблется от 0,5% в Севастополе и 1 \% в Архангельске до 16 \% в прибрежных районах Японского моря. ${ }^{158}$ В случае сильных ветров погрузочно-разгрузочные работы либо замедляются, либо останавливаются, что приводит к увеличению времени обработки судна в порту.

Другим фактором воздействия на портовые операции является ограничение видимости до 50 м и менее, что происходит при сильных туманах и ливневом снеге. Однако повторяемость туманов со столь сильно ограниченной видимостью в прибрежных районах составляет лишь небольшой процент от общего числа.

\footnotetext{
${ }^{156}$ Гидрометеорология и гидрохимия морей СCCP. Тома I-VI, VIII-X. Вып.1. Гидрометеорологические условия. Гидрометеоиздат, 1989-1991 г.; Гидрометеорология и гидрохимия морей СССР. Tома I-VI, VIII-X. Вып. 2. Гидрохимические условия и океанологические основы формирования биологической продуктивности. Гидрометеоиздат, 1989-1991 г.; Guide to the Applications of marine Climatology. WMO-№ 781, Secretatiat of the World Meteorological Organization, Geneva, Switzerland, 1994.

157 Гидрометеорология и гидрохимия морей СCCP. Тома I-VI, VIII-X. Вып.1. Гидрометеорологические условия. Гидрометеоиздат, 1989-1991 г.; Гидрометеорология и гидрохимия морей СССР. Tома I-VI, VIII-X. Вып. 2. Гидрохимические условия и океанологические основы формирования биологической продуктивности. Гидрометеоиздат, 1989-1991 г.; Guide to the Applications of marine Climatology. WMO-№ 781, Secretatiat of the World Meteorological Organization, Geneva, Switzerland, 1994.

158 Гидрометеорология и гидрохимия морей СССР. Тома I-VI, VIII-X. Вып. 1. Гидрометеорологические условия. Гидрометеоиздат, 1989-1991 г.
} 
В последние десятилетия с увеличением размеров судов, особенно танкеров, появился еще один фрактор воздействия на портовые операции сильные течения в узостях на входе в порт. Дело в том, что чем больше длина судна, тем в большей степени оно подвержено воздействию поперечных к курсу составляющих морских течений, что приводит к сносу судна с линии пути. В условиях открытого моря такое воздействие течений не существенно, но при входе судна в порт, в условиях ограниченного пространства для маневра, оно представляет опасность и требует не только более высокой квалификации экипажа, но и увеличения дистанции между судами, а, значит, и времени, необходимого для входа судна в порт и выхода из него, что увеличивает период нахождения судна в порту или на рейде в ожидании разрешения на вход. К сожалению, количественная оценка повторяемости неблагоприятных направлений течений в настоящее время затруднена из-за отсутствия режимных данных о течениях в конкретных районах.

В районах с песчаным, легко размываемым дном увеличение повторяемости штормов и ветрового волнения увеличит заносимость морских каналов на подходах к портам, что потребует выполнения дополнительного объема дноуглубительных работ для поддержания работоспособности порта.

Во многих случаях, для изменения характеристик ветрового волнения и сгонно-нагонных явлений достаточно, чтобы изменилось преобладающее направление сильных ветров (даже без изменения их скорости), поскольку это способно изменить длину разбега ветровой волны (чем больше разбег, тем выше волны) и величину перпендикулярной к линии берега составляющей ветра (чем она больше, тем интенсивнее сгонно-нагонные явления). Однако, в отличие от увеличения скорости ветра, изменение его преобладающего направления при изменении климата может стать как неблагоприятным, так и благоприятным фрактором для судоходства и портовых операций (т. е. оно может как увеличивать климатические риски, так и уменьшать их), в зависимости от угла между направлением ветра и линией берега, а также конфигурации волнозащитных гидротехнических сооружений в портах относительно преобладающего направления распространения сильного волнения.

Ожидаемый и уже происходящий подъем уровня моря благоприятен для судоходства, поскольку, при прочих равных условиях, обеспечивает увеличение навигационных глубин без необходимости выполнения дноуглубительных работ. Однако для портового хозяйства увеличение среднего уровня моря создаст дополнительные трудности, поскольку потребует реконструкции (увеличения высоты) причальных стенок и, особенно, волнозащитных сооружений акваторий портов.

Еще одним фрактором является изменение солености морских вод в прибрежных районах, что чревато изменением осадки судов - при уменьшении солености осадка увеличивается (из-за того, что более пресная вода обладает меньшей плотностью), а при увеличении солености - уменьшается. Однако это явление и характер его воздействия также будет в значительной мере 
локальными. Так, порты, находящиеся в устьях крупных рек, при увеличении их стока в результате изменения климата будут испытывать уменьшение солености на своей акватории и, как следствие, потребность в увеличении навигационных глубин. С другой стороны, порты, находящиеся вдали от устьев рек, могут не испытывать такого негативного воздействия.

\section{Морская разведка, добыча и транспортировка энергоресурсов}

Морская разведка и добыча энергоресурсов осуществляется, как правило, со специальных нефтяных платфрорм, имеющих разную конструкцию, в зависимости, в том числе, от глубины места и других фризико-географических и климатических условий. Платформы могут быть стационарными (стоящими основанием на дне) или мобильными (к последним относятся плавающие разведочные буровые платформы с временной опорой на дно). Факторами воздействия являются ветровое волнение, колебание высоты уровня моря, ветер (в том числе совместно с температурой и влажностью), а также ледяные поля и обледенение.

Ветровое волнение и колебания высоты уровня моря входят в число факторов, учитываемых при проектировании нефтяных платформ. При этом в расчеты конструкции закладываются максимальный, а в случае мобильных платформ, и минимальный, уровень моря и максимальные высоты ветровых волн (или их максимальная энергия) за расчетный период эксплуатации платформы. Обычно в этих целях используются значения максимальной высоты волн и уровня моря, возможные один раз в 50 или 100 лет. Характерные значения максимальной высоты ветровых волн, возможные один раз в 50 лет на омывающих Российскую Федерацию неарктических морях составляют от 5-6 м на Черном море до более 10 м на Японском море.

Ветровое волнение воздействует не только на морские платформы, но и береговую инфраструктуру (нефте- и газохранилища, нефтяные терминалы и т. п.), а также на донные нефте- и газопроводы. Воздействие на береговую инфраструктуру происходит в результате разрушения берегов и морского дна штормовыми волнами, а в случае с морскими трубопроводами - ледяными образованиями, основания которых лежит на дне (стамухи).

В зимний период по мере потепления климата и таяния льда ожидается увеличение площади свободной от льда поверхности моря, что увеличит вероятность штормов и повышенных волновых нагрузок на платформы в зимние месяцы.

Скорость ветра учитывается при проектировании платформы для расчета ветровой нагрузки, но повторяемость сильных ветров (более $15 \mathrm{~m} / \mathrm{c}$ и особенно более $25 \mathrm{~m} / \mathrm{c}$ ) важна также для оценки климатических рисков ограничения или полного прекращения работы платорормы ради обеспечения безопасности персонала, работающего вне помещения. При этом в случае низких температур и высокой влажности предельная скорость ветра, при 
которой допускается работа персонала вне помещения, как правило, уменьшается.

Сильные ветры также ограничивают работу вертолетов, обслуживающих морские платформы, однако для каждого типа воздушных судов установлена своя предельная скорость ветра для взлета и посадки. В случаях, когда транспортировка добытой нефти на берег осуществляется наливными судами, сильный ветер и связанное с ним волнение осложняют процесс перекачки нефти на судно, а при слишком сильных ветрах, перекачка прекращается в интересах обеспечения безопасности платформы и предотвращения попадания нефти в морскую среду.

Ограниченная видимость влияет на работу нефтяных платформ путем воздействия на работу вертолетов, а также на операции по подходу нефтеналивных судов к платформе.

Погодно-климатические фракторы воздействия на транспортировку энергоресурсов по морю аналогичны факторам воздействия на судоходство, с той разницей, что при аварии нефтеналивного судна ущерб наносится не только судну, экипажу и судовладельцу, но и окружающей среде.

\section{Рыболовство}

Погодно-климатические факторы воздействуют на рыболовство двояко путем воздействия на объем рыбных ресурсов и на процесс лова.

Воздействие на рыбные ресурсы связано с влиянием температуры, солености, кислотности $\mathrm{pH}$ и содержания кислорода в морской воде на процессы размножения и нагула рыб, их миграцию. Для каждого вида рыб имеются свои пределы толерантности параметров морской среды, при выходе за которые рыбы гибнут или мигрируют в районы с более благоприятными условиями. Даже в случаях, когда изменения характеристик морской среды не выходят за пределы толерантности вида, такие изменения могут влиять на ежегодную урожайность. ${ }^{159}$

К сожалению, в настоящее время моделирование изменения гидрологогидрохимического режима омывающих Россию морей под влиянием будущих изменений метеорологического режима находится в стадии зарождения. Поэтому сейчас можно говорить лишь о тенденциях изменения гидрологического режима на основе выявленных трендов соответствующих характеристик и экспертных оценок возможного влияния их на климатические риски для отдельных видов морской деятельности. При этом сколько-нибудь достоверные количественные оценки изменения климатических рисков для морской деятельности под влиянием изменения климата пока вряд ли возможны.

Расчеты по специализированным моделям «климат - состояние морской среды - рыбное поголовье» показывают, что изменение климата приведет к

\footnotetext{
${ }^{159}$ Гидрометеорология и гидрохимия морей ССCP. Тома I-VI, VIII-X. Вып. 2. Гидрохимические условия и океанологические основы формирования биологической продуктивности. Гидрометеоиздат, 1989-1991 $\Gamma$.
} 
миграции рыбы в районы с более благоприятными условиями, а частично - к уменьшению поголовья при резком изменении состояния окружающей среды. ${ }^{160}$ В результате произойдет изменение традиционных районов лова и размеров уловов, а также возникнет необходимость перераспределения квот вылова между странами с крупным рыболовным флотом.

На процесс лова оказывают влияние прежде всего ветер и связанное с ним ветровое волнение. В частности, руководствами по безопасности для советских, а затем и российских рыболовных судов установлено, что по достижении скорости ветра 15 м/с и высоте волны 4 м средние рыболовные траулеры прекращают работу или не выходят из порта, а средние и большие морозильные рыболовные траулеры ограничивают работу, причем прекращается перегрузка улова на суда-обработчики рыбы. При скорости ветра 17 м/с и высоте волн около 6 м все типы судов прекращают лов рыбы. ${ }^{161}$ Ожидаемое увеличение повторяемости циклонов и связанных с ними штормовых ветров и ветрового волнения осложнит работу рыболовецких судов, увеличит суммарное время вынужденных перерывов в работе, вызванных штормовой погодой и тем самым уменьшит рентабельность рыболовства.

\section{Ущербы}

Очевидно, что опасное явление способно принести ущерб морской деятельности только в том случае, если на акватории или прибрежной территории, подверженных его воздействию, находятся какие-либо экономические или социальные объекты (транспортные и рыболовные суда, объекты портовой, нефтедобывающей и иной инфраструктуры, населенные пункты, сельскохозяйственные угодья и т. п.). Экономический ущерб характеризуется денежным выражением негативных последствий опасных событий, явлений и процессов. Однако все виды ущерба тесно связаны друг с другом, при этом социальный, экологический и моральный ущербы также могут иметь денежное выражение. ${ }^{162}$

Ущерб подразделяется на прямой и косвенный.

Например, прямой экономический ущерб от затопления включает ${ }^{163}$ :

\footnotetext{
${ }^{160}$ Poloczanska E.S., Hoegh-Guldberg O., Cheungm, Pörtner H.-O., Burrows M., 2014: Cross-chapter box on observed global responses of marine biogeography, abundance, and phenology to climate change. In: Climate Change 2014: Impacts, Adaptation, and Vulnerability. Part A: Global and Sectoral Aspects. Contribution of Working Group II to the Fifth Assessment Report of the Intergovernmental Panel on Climate Change [Field, C.B., V.R. Barros, D.J. Dokken, K.J. Mach, M.D. Mastrandrea, T.E. Bilir, M. Chatterjee, K.L. Ebi, Y.O. Estrada, R.C. Genova, B. Girma, E.S. Kissel, A.N. Levy, S. MacCracken, P.R. Mastrandrea, and L.L. White (eds.)]. Cambridge University Press, Cambridge, United Kingdom and New York, NY, USA, p. 123-127.

${ }^{161}$ Guide to the Applications of marine Climatology. WMO-№ 781, Secretatiat of the World Meteorological Organization, Geneva, Switzerland, 1994.

162 Рогозин А.А., 1993: Оценка и картографирование опасности и риска от природных и техно-природных процессов (история и метеорология). Проблемы безопасности при чрезвычайных ситуациях, № 3, с. 1641; Бахирева Л.В., Кофф Г.Л. и др., 1989: Оценка геологического и геохимического риска в схемах охраны культурно-исторических зон (на примере Московского региона). Инженерная геология, № 6, c. $137-147$.

163 Отчет ФГБУ «ГГИ» о НИР по теме 1.3.4.2: Разработка экономически целесообразных адаптационных стратегий для технических систем с учетом природных и социально-экономических особенностей регионов к изменению и изменчивости климата, направленная на минимизацию климатических рисков.
} 
- потери от повреждений основных производственных и непроизводственных фондов (разрушение сооружений, оборудования, подъездных путей, и т. д.);

- потери оборотных фрондов на объектах (горюче-смазочные материалы, грузы в порту и т. д.);

- потери выпускаемой продукции за период прекращения производственного цикла (перевалки грузов в порту);

- д дополнительные затраты на проведение эвакуации имущества;

- эвакуация персонала;

- потери личной собственности граждан.

К косвенным ущербам относят материальные потери, вследствие нарушения хозяйственных связей в экономике - сокращения производства, расходов на освоение новых земель взамен выбывших из оборота при затоплении, затрат на медицинское обслуживание, убытков в форме непроизведенной промышленной и сельскохозяйственной продукции, невыполненных транспортных перевозок (в случае затопления территории портов, дорожно-подъездной сети) и т. д.

Например, в результате подъема уровня моря может быть разрушен производственный объект, потери продукции которого являются основой для развития каскада косвенных потерь. Этот каскад образуется в связи со сложным характером межотраслевых потоков промежуточной продукции в экономике, направленных на выпуск конечной продукции. Существует процесс последовательного наслоения косвенных потерь, имеющий вид «ветвящегося дерева». Например, потери электроэнергии при разрушении крупной электростанции сказываются на недовыпуске продукции в других отраслях экономики, включая прекращение портовых операций. В свою очередь, это обстоятельство отрицательно влияет на последующие межотраслевые потоки.

Сведения об ущербе, обусловленном тем или иным неблагоприятным или опасном явлением, как правило, отсутствуют. Публикуются разрозненные данные об ущербах, связанных с экстремальными, поражающими явлениями, в первую очередь - сильными наводнениями и штормами в прибрежных районах.

Особое значение имеет экологический ущерб, возникающий, например, когда сильные ветер и ветровое волнение приводят к кораблекрушению нефтеналивных судов и разливу нефтепродуктов в море. Наиболее известным примером служит разлив мазута при аварии танкера Волгонефрть-139 в Керченском проливе в ноябре 2007 г. Только затраты на очистку берегов и прибрежных акваторий от мазута и утилизацию возникающих при этом отходов (песка с примесью мазута) составили около 213 млн руб. ${ }^{164}$ На основе действующей методики Росприроднадзор оценил фрактический ущерб для окружающей среды в 6 млрд руб.

Раздел ФГБУ «ГГИ»: Методика расчета рисков и оценки ущерба от увеличения количества осадков и наводнений (промежуточный за 2011 г.), СПб, 2011 г.

${ }^{164}$ Oil spill accident in the Kerch Strait in November 2007. Edited by Alexander Korshenko, Yuriy Ilyin, Violeta Velikova. Black Sea Commission Publications 2011, Moscow, Nauka, 288 p. 
Для оценки вероятного ущерба используются различные расчетные методы, которые, однако, также далеко не всегда обеспечены необходимыми оценками стоимости различных фондов. Так, на основе методики МЧС России и Госгортехнадзора Российской Федерации по оценке ущерба от затопления при наводнениях на реках ${ }^{165}$, введенной в действие в 2003 г., была разработана методика оценки ущерба, вызванного затоплением в результате подъема уровня моря и штормовых нагонов. Согласно этой методике ущерб основным фондам зависит от предполагаемой степени разрушения (утраты остаточной балансовой стоимости), которая принимается по зонам затопления. Критерии разделения зоны затопления на зоны сильных, средних и слабых разрушений для основных фондов допускается принимать по специальному руководящему документу. ${ }^{166}$ Степень разрушения зависит от степени затопления территории объекта, которая определяется уровнем вод при затоплении. Исходные данные принимаются по фрактической информации, предоставленной субъектами Российской Федерации для наихудших условий затопления.

Для объектов морской деятельности, воздействие погодноклиматических факторов на которые приводит к приостановке их деятельности (в частности, портовые операции при тумане и усилении ветра и лов рыбы при усилении ветра) может оцениваться в относительных единицах, а именно в процентах стоимости портовых операций и невыловленной рыбы, соответственно. Очевидно, что в случае предположения круглосуточной работы объекта, такая оценка в относительных единицах численно совпадает с вероятностью наступления неблагоприятных условий (сильного ветра при ловле рыбы или суммы вероятностей сильного ветра и тумана при портовых операциях).

Оценка ожидаемого ущерба при наступлении неблагоприятного явления используется при расчете экономического риска морской деятельности, представляющего собой произведение вероятности наступления неблагоприятного явления на величину ожидаемого ущерба. Как следствие, при оценке экономического риска следует принимать во внимание даже маловероятные события (с вероятностью $1 \%$ и менее), но потенциально имеющие значительные последствия (высокую величину ожидаемого ущерба). ${ }^{167}$

\footnotetext{
${ }^{165}$ РД 03-626-03. Методика определения размера вреда, который может быть причинен жизни, здоровью физических лиц, имуществу физических и юридических лиц в результате аварии гидротехнического сооружения (утв. приказом МЧС РФ и Госгортехнадзора РФ от 15 августа 2003 г. № 482/175a) (согл. письмом Минэкономразвития РФ от 14 марта 2003 г. № МЦ-234/23).

${ }_{166}$ РД 03-626-03. Методика определения размера вреда, который может быть причинен жизни, здоровью физических лиц, имуществу физических и юридических лиц в результате аварии гидротехнического сооружения (утв. приказом МЧС РФ и Госгортехнадзора РФ от 15 августа 2003 г. № 482/175a) (согл. письмом Минэкономразвития РФ от 14 марта 2003 г. № МЦ-234/23), табл.П.3.1.

${ }^{167}$ Edenhofer O., Pichs-Madruga R., Sokona Y., et al., 2014: Technical Summary. In: Climate Change 2014: Mitigation of Climate Change. Contribution of Working Group III to the Fifth Assessment Report of the Intergovernmental Panel on Climate Change [Edenhofer, O., R. Pichs-Madruga, Y. Sokona, et al. (eds.)]. Cambridge University Press, Cambridge, United Kingdom and New York, NY, USA.
} 
Наблюдаемые в настоящее время изменения глобального климата протекают с наибольшей интенсивностью в арктическом регионе. Арктика характеризуется крайней уязвимостью к изменениям климата, что ведет к серьезным экологическим, социальным и экономическим последствиям. При этом ввиду разнообразия природно-климатических и социально-экономических условий ожидаемые последствия будут существенно различаться в разных регионах Арктики.

Морская деятельность в Арктике, стимулируемая климатическими изменениями и, в частности, таянием льдов, включает в себя:

- поиск, разведку и освоение месторождений нефти и газа на шельфе Арктики;

- морские грузоперевозки;

- лов рыбы и иных морепродуктов;

- морской арктический туризм;

- научные исследования;

- другие виды морской деятельности.

Применительно к арктической морской деятельности к числу основных рисков относятся следующие ${ }^{168}$ : технические, погодные, операционные (производственные), экологические, репутационные и риски, связанные с охраной труда (риски для здоровья и безопасности работников и подрядчиков).

Технические риски обусловлены:

- низкими температурами, оказывающими влияние на свойства различных материалов;

- наличием айсбергов, морского льда, порождающего дополнительные нагрузки на оборудование, особенно при волнении моря;

- морским брызговым обледенением судов, нефтегазовой инфраструктуры, различного оборудования, обеспечивающего безопасность жизнедеятельности;

- обледенением вследствие выпадения атмосферных осадков.

Погодные риски обусловлены, с одной стороны, низкими температурами, сильными ветрами, обильными снегопадами, туманами и сильной дымкой, ухудшающими видимость, а с другой, недостаточно качественным гидрометеорологическим обеспечением, что связано с недостатком необходимой гидрометеорологической информации и недостаточной точностью прогнозов погоды и ледовой обстановки.

Операционные (производственные) риски связаны с удаленностью мест операционной деятельности и отсутствием необходимой инфраструктуры, ограниченным спутниковым покрытием (выше 70-й параллели), что существенно влияет на связь и работу глобальной навигационной системы.

\footnotetext{
${ }^{168}$ Assessment of international standards for safe exploration, production and transportation of oil and gas in the Barents Sea. DNV-GL, 2012. 136 p.
} 
В результате могут возникать проблемы при принятии решений и экстренном реагировании на возникшие нештатные ситуации.

Риски охраны труда связаны с тяжелыми условиями работы, обусловленными низкими температурами, штормовыми ветрами, снегопадами, обледенением. Полярная ночь усугубляет риски охраны труда, поскольку, вопервых, персоналу приходится работать в условиях темноты, а, во-вторых, работа поисково-спасательных служб в условиях полярной ночи существенно затруднена.

Экологические риски обусловлены возрастающими грузоперевозками и разработкой нефтяных и газовых месторождений, приводящими к неконтролируемым утечкам гидрокарбонов в окружающую среду, вызывая ее загрязнение и разрушение естественной среды обитания видов. Заметим, что арктические экосистемы имеют очень малую скорость самовосстановления.

Репутационные риски обусловлены авариями и несчастными случаями, привлекающими внимание общественности и государственных надзорных органов, что наносит урон репутации компании, работающей в арктическом регионе.

Сложные природно-климатические условия в арктических морях и на арктическом шельфе создают высокие природные риски для безопасности морского судоходства, для инфраструктуры, обеспечивающей разработку природных ресурсов, увеличивают стоимость проектов, в том числе вследствие обеспечения экологической безопасности.

К опасным гидрометеорологическим явлениям и аномалиям, которые могут вызвать аварии и катастрофы, относятся сильный (штормовой) ветер, низкая температура воздуха, обледенение, плохая видимость, морское волнение, штормовые нагоны и сгоны у берегов. Серьезные риски обусловлены сильными ледовыми сжатиями судов и навалами льда на морские и береговые сооружения.

Изменения климата в той или иной степени сказываются на различных компонентах природной среды, вызывая, в частности, изменения экстремальных значений характеристик состояния атмосферы, морского льда и водной среды в арктических морях, влияющих на экологическую безопасность. Поэтому важной задачей является оценка вероятности экстремальных значений и ее эволюции под влиянием изменений климата.

Экстремально низкие температуры воздуха на акватории арктических морей увеличивают риск таких опасных явлений как обледенение судов и добывающих платформ на морском шельфе, способствуют интенсивному ледообразованию, создающему опасные ситуации при необычно раннем замерзании моря и быстром увеличении толщины льда.

Морская деятельность, подверженная погодным и климатическим рискам, в свою очередь, является источником возникновения экологических 
рисков. ${ }^{169}$ Разработка и транспортировка углеводородного сырья создает риски аварий, при этом суровые климатические и погодные условия, а также удалённость месторождений от существующей развитой инфраструктуры очень сильно затрудняют ответные действия и выполнение рекультивационных работ. Имеющиеся технологии сбора нефти с поверхности в условиях высоких волн и суровых погодных условий оказываются малоэффективными. Особо сложной проблемой являются разливы нефти на лед и подо льдом. Угроза крупного разлива - еще один серьезнейший риск, связанный с арктическими перевозками. Ущерб от разливов напрямую зависит от его местоположения и времени.

Помимо экологических рисков морская деятельность генерирует риски, которые в последнее время также стали относить к категории климатических. Выбросы двигательных установок, фракельное сжигание попутного газа, утечки метана в процессе добычи и транспортировки углеводородов сопровождаются выбросами парниковых газов и летучих органических соединений. Объемы неконтролируемых выбросов парниковых газов при глубоководном бурении намного превосходят те, что имеют место при разработке месторождений на суше и при малой глубине моря в силу существенно больших энергетических затрат. К тому же, чем дальше от берега находится буровая установка, тем больше затраты на перевозку побочных продуктов для последующей утилизации. Поэтому факельное сжигание попутного газа на буровой установке - общепринятая мировая практика.

Загрязнение льда нефтью приводит к убыстрению его таяния. В результате любой разлив нефти в Арктике будет способствовать быстрому расширению пространства открытой воды. Открытая вода, в свою очередь, разогревается солнечными лучами в несколько раз быстрее, чем поверхность снега и льда. В этих случаях нефтеразработки в арктических морях, покрытых льдом, будут сопровождаться ускорением сокращения ледовитости.

Окружающая среда Арктики характеризуется сезонными колебаниями уязвимости, возрастающей в летние месяцы, поскольку в летний сезон производственная деятельность интенсифицируется. Однако имеются регионы, которые особо уязвимы в зимний период из-за того, что в этих регионах происходит нерест рыбы и зимовка птиц.

\section{4. Управление климатическими рисками как основа адаптации к изменению климата}

Существуют различные определения понятия «управление климатическими рисками». В частности, целевая группа по управлению климатическими рисками Комиссии по климатологии ВМО определила его как системный и скоординированный процесс, в котором климатическая

\footnotetext{
169 Мещерин И.В., 2008: Управление рисками при реализации крупных морских газотранспортных Проектов. Проблемы анализа риска, т. 5, № 4. С. 14-29; Lindoe P.H., M. Baram, O. Renn (Eds.), 2015: Risk governance of offshore oil and gas operations. Cambridge: Cambridge University Press. 452 p.
} 
инфрормация используется для снижения рисков, связанных с изменчивостью и изменением климата, и реализации возможностей для повышения устойчивости социальных, экономических и экологических систем. ${ }^{170}$

Первым шагом в этом процессе является анализ рисков. Анализ климатических рисков - это исследование, направленное на выявление различных видов риска, их количественное определение и прогноз их взаимодействия с антропогенной средой. Данный анализ выполняется в несколько этапов: идентификации риска, количественной оценки риска и прогноза риска.

Итерационный характер процессов управления климатическими рисками можно также представить в виде цикла (рис. 4.1) - от сбора и анализа информации следует двигаться к оценке современных и будущих рисков, затем наступает этап разработки адаптации и мониторинг ее результатов. На основе вновь полученных климатических и социально-экономических данных предполагается выход на следующий виток управления рисками.

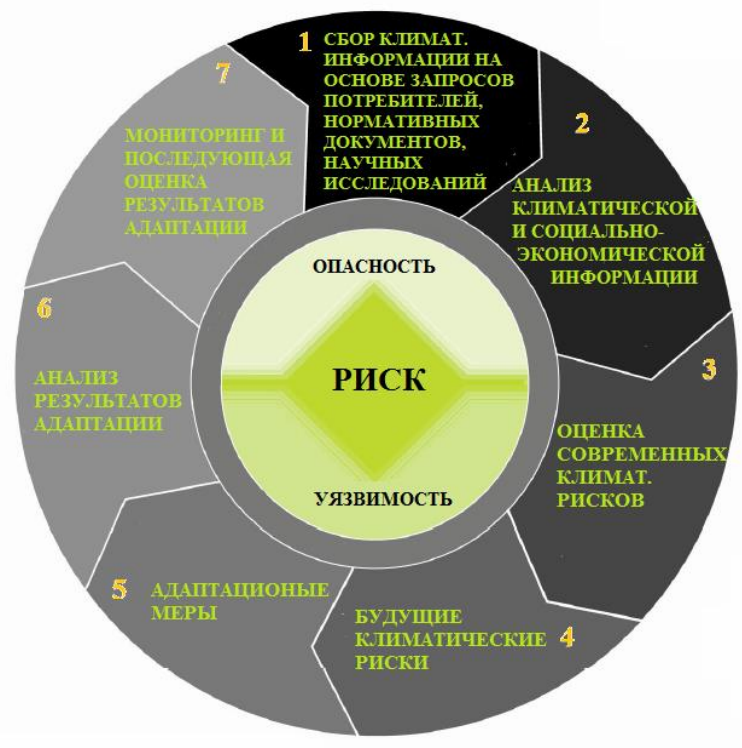

Рис. 4.1 Итеративный подход к управлению рисками и разработке адаптации.

Понятно, что каждый этап предполагает тесное взаимодействие с потребителями климатической информации и лицами, принимающими решения.

Разработке количественных оценок риска должна предшествовать идентификация риска. Идентификация климатического риска - достаточно сложный процесс, так как требует знаний в областях применения климатической информации. Такие знания позволяют определить весь спектр

\footnotetext{
${ }^{170}$ Martínez R., Hemming D., Malone L. Improving Climate Risk Management at Local Level - Techniques, Case Studies, Good Practices and Guidance for World Meteorological Organization Members (Chapter 21). InTech: Risk Management - Current Issues and challenges (Edited by Nerija Banaitiene, 584 p., 12 September 2012).
} 
возможных не только первичных, но и вторичных последствий опасных климатических условий.

В некоторых случаях угрожающим фрактором при оценке климатического риска может служить не само опасное явление (ОЯ), а создаваемое им природное или техногенное событие (или распределение событий), которое, в свою очередь, воздействует на тот или иной реципиент. При этом рекомендуется рассматривать и вторичный риск исходного ОЯ, т. е. последствия ОЯ в качестве угрожающего фрактора риска. Следует также заметить, что при идентификации рисков в понятие «риск» часто вкладывают различный смысл. Например, ураган влечет за собой разрушения, при которых гибнут люди. Можно говорить о риске урагана, о риске разрушений и о риске гибели людей от урагана. Так как риск является функцией угрожающего фрактора и ущерба, допустимы, по-видимому, все фрормулировки, однако в каждом конкретном случае необходимо четко определить, о каком риске идет речь.

Анализируя факторы риска, необходимо определить все возможные реципиенты риска. Согласно наиболее общей классификации, используемой при анализе климатических рисков, реципиенты делятся на три основные группы: природные, социальные и технические. ${ }^{171}$ Дополнительно выделяются подгруппы: например, социо-природные (города), природно-техногенные (ветро-, гелиоустановки и т. п.) реципиенты.

Реципиентом (предметом, находящимся под воздействием ОЯ, неблагоприятных условий погоды (НУП), аномальных климатических условий (АКУ)) могут служить:

- объект, система объектов (объектом может быть человек);

- процесс, комплексный процесс;

- территория (страны, региона, области, города, поселения),

- отрасль экономики.

Показатели реципиентов не являются типовыми, но в каждом конкретном случае зависят от вида реципиента и решаемой задачи. Если реципиентом является объект, описывается его назначение и особенности устройства; реципиент-процесс характеризуется назначением и временем протекания; для реципиента-отрасли указывается ее инфраструктура; для реципиентатерритории необходимо очертить границы реципиента (объекта, системы объектов, района действия процесса, территории).

\section{Мониторинг фракторов риска}

Мониторинг гидрометеорологических условий занимает важное место в комплексе мероприятий, направленных на прогноз рисков. Необходим не только метеорологический (климатический) мониторинг, но и мониторинг уязвимости реципиента (технический мониторинг), включающий все

171 Акимов В.А., Лесных В.В., Радаев Н.Н., 2004: Основы анализа и управления риском в природной и техногенной сферах. М.: Деловой экспресс. 352 с. 
составляющие уязвимости: подверженность, чувствительность, потенциал адаптивности. Ведь с течением времени изменяются свойства реципиента. Здания и сооружения стареют, исчерпывается срок их эксплуатации и соответственно становится другой их реакция на воздействия метеорологических явлений. В результате мониторинга определяются тренды характеристик метеорологических величин, поведение экстремумов и специализированных климатических показателей, а также характер и степень изменения реципиентов риска. В условиях нестационарного климата адекватные оценки трендов становятся особенно актуальными, т. к. наблюдаемые климатические изменения могут вносить коррективы в расчетные характеристики метеорологических величин.

В России мониторинг климатической составляющей входит в Единую государственную систему экологического мониторинга. За функционирование данной системы отвечает Министерство природных ресурсов. Слежению за метеорологическими процессами, т. е. ОЯ и НУП, которые по силе, масштабу распространения или продолжительности оказывают катастрофическое влияние на здоровье и жизнедеятельность населения, естественно, уделяется особое внимание.

Для целей мониторинга экстремальных значений климатических параметров, наиболее важных для конкретных отраслей экономики и социальной сферы, Комиссией по климатологии ВМО был разработан программный продукт ClimPACT ${ }^{172}$, позволяющий оперативно оценить изменения во времени экстремальных значений климатических параметров, наиболее значимых для конкретных отраслей экономики и социальной сореры. ${ }^{173}$

Мониторинг других составляющих риска - подверженности и уязвимости реципиентов - в настоящее время не ведется систематически. Для его выполнения климатологи должны тесно сотрудничать со специалистами в соответствующих отраслях экономики.

И метеорологический, и технический мониторинги могут быть глобальными, региональными, национальными и местными. Надо учитывать, что, когда глобальные и региональные тренды характеристик опасных явлений имеют разную направленность, следует уделять большее внимание глобальным трендам, так как региональные тренды менее надежны из-за

\footnotetext{
${ }^{172}$ Alexander L., Yang H., Perkins S. (2013). ClimPact. Indices and software. World Climate Programme. New South Wales University of Technology. 51 p.

${ }^{173}$ Комплекс специализированных климатических индексов, рассчитываемых с помощью СlimРАСТ, усовершенствован в соответствии с целями Глобальной рамочной основы для климатического обслуживания (ГРОКО), т.к. одной из основных её задач является создание климатической продукции, максимально учитывающей нужды потребителей при решении различных прикладных задач. Первоначально климатические индексы предназначались для оценки влияния изменения и изменчивости климата на здравоохранение, водные ресурсы и сельское хозяйство. В дальнейшем, на 16-й сессии Комиссии по климатологии в 2014 г. было принято решение расширить сферу применения ClimPACT и для других климатозависимых секторов, в частности, для энергетического Программа ClimPACT может быть также привлечена для оценок будущих изменений индексов влияния на основе результатов климатического моделирования
} 
большого количества неопределенностей. Изменения повторяемости и интенсивности неблагоприятных явлений наиболее значимы на региональном и глобальном уровнях, а изменения подверженности и уязвимости инфраструктуры и социальной сферы - на местном и национальном уровнях.

Очевидно, что наиболее ощутимые воздействия на объекты инфраструктуры можно ожидать в тех районах, где наблюдается увеличение подверженности и уязвимости этих объектов (увеличение числа старых зданий, в которых не производился капитальный ремонт; частые нарушения строительных норм при возведении новых зданий; рост населения; появление опасных объектов, например, атомных станций и т. д.) при одновременном росте количества НУП в данном районе (увеличение повторяемости оттепелей и заморозков, занормативных снеговых нагрузок и т. д.).

\section{Ожидаемые климатические риски}

Ожидаемые климатические риски рассчитываются по результатам моделирования будущего климата и информации о стратегиях социальноэкономического развития тех или иных районов или отраслей экономики.

Имеется обширная литература по описанию сценариев и модельных оценок изменений климата в XXI в. ${ }^{174}$ Наряду с глобальными моделями для получения более детализированной в пространстве информации о будущем климате в регионах России могут применяться региональные климатические модели. ${ }^{175}$

В ряде случаев из-за недостаточного (для количественного описания будущих изменений специализированных климатических показателей и их комплексов, а также ОЯ и НУП) пространственно-временного разрешения результатов прямых модельных расчетов приходится прибегать к косвенным. По имеющемуся климатическому материалу (данным наблюдений) устанавливаются связи требуемых специализированных характеристик с базовыми показателями. ${ }^{176}$ При этом предполагается (и это сильное допущение), что эти связи сохранятся и в будущем.

\section{Медленные климатические изменения}

На Канкунской конференции по изменению климата $(2010)^{177}$ было принято решение относить к медленным климатическим изменениям подъем уровня моря, рост температуры воздуха, повышение кислотности океанских вод, таяние материкового льда, засоление почв, деградацию лесов и земельных угодий, уменьшение биоразнообразия, опустынивание. По своей природе эти изменения значительно отличаются от экстремальных

\footnotetext{
${ }^{174}$ Росгидромет, 2014;

175 Катцов, В.М., Школьник И.М., Ефимов С.В., 2017: Перспективные оценки изменений климата в российских регионах: детализация в физическом и вероятностном пространствах. Метеорология $u$ гидрология. № 7, с. 68-80.

176 Кобышева Н.В., Наровлянский Г.Я., 1978: Климатологическая обработка метеорологической информации. Л.: Гидрометеоиздат. 296 с.

$177 \mathrm{http}: / /$ unfccc.int/meetings/cancun_nov_2010/meeting/6266.php .
} 
климатических явлений и имеют долгосрочные и широкомасштабные последствия. При этом медленные изменения могут оказывать ощутимое влияние на частоту, интенсивность, пространственное распределение и длительность экстремальных явлений. Важным является тот фракт, что в долгосрочной перспективе постепенные изменения могут затронуть значительно большее число людей, чем экстремальные явления.

Учитывая сложный характер медленно текущих климатических изменений и не до конца ясные механизмы взаимосвязи между ними, необходимо выработать особые подходы к оценке и управлению рисками, обусловленными этими процессами. Одним из основных является интегрированный подход, сочетающий кратковременное и долговременное планирование действий по уменьшению негативных последствий климатических изменений. При этом необходимо оценивать совместное действие медленно текущих климатических изменений и экстремальных погодных явлений на рассматриваемые объекты. Примером такого подхода может быть проект CliPLivE (Climate Proof Living Environment - Климатически устойчивая среда обитания), который выполнялся в 2007-2013 гг. гидрометслужбами России и Финляндии. ${ }^{178}$ Исследования были направлены на анализ комплексного воздействия повышения уровня моря и усиливающихся штормов на эрозионные процессы на побережье Балтийского моря. Оценка комплексного риска для береговой инфраструктуры основывалась на матрице риска, включающей информацию о геологической, климатической и экологической составляющих риска для городской среды. В результате были определены и нанесены на карту четыре уровня комплексного риска для жилых массивов, промышленных предприятий, транспортной инфраструктуры, водоснабжения, лесного хозяйства и т. д. Полученная картина будет служить основой для оценки будущего пространственного распределения величины природного риска для городской среды.

\section{Оценка климатического риска}

В большей части работ, посвященных климатическим рискам, возникающим под воздействием ОЯ ${ }^{179}$, представлены в основном качественные оценки климатических рисков (от «весьма низкого» до «весьма высокого»).

Для расчета техногенных рисков в литературе начала XXI в. $^{180}$ используются аналитические методы. Аналогичные разработки стали

\footnotetext{
${ }^{178}$ http://cliplive.infoeco.ru/index.php?id=4

179 Русин И.Н., 2003: Стихийные бедствия и возможности их прогноза. Учебное пособие. СПб: РГГМУ, 138 с.; Карлин Л.Н., Абрамов В.М., 2006: Управление энвиронментальными и экологическими рисками. СПб: РГГМУ, 332 с.; Адаптация к изменению климата в странах Европы и Центральной Азии (ЕЦА). Информационный бюллетень Всемирного Банка, июнь, 2009, вып. 5, 5 с.; Атлас природных и техногенных опасностей и рисков чрезвычайных ситуаций. Российская Федерация (под общ. ред. С.К.Шойгу). М., 2011: Феория. 720 с.

${ }^{180}$ Акимов В.А., Лапин В.Л., Панов В.И., Пучков В.А., Тамаков В.И., Фалеев М.И., 2002: Надежность технических систем и техногенный риск. Учебное пособие. М.: ЗАО ФИД «Деловой экспресс», 368 с.
} 
появляться и для климатических рисков. ${ }^{181}$ Например, в основу косвенного метода расчета экономического риска от опасных явлений, может быть положена математическая интерпретация риска как произведения вероятности природного явления на уязвимость некоторого объекта, подвергающегося воздействию этого явления. ${ }^{182}$ Уязвимость технических систем может быть выражена через ущерб (фактические потери реципиента). Однако доступные данные об ущербе часто не полны или искажены, а иногда полностью отсутствуют. Поэтому приходится прибегать к косвенным методам, а имеющуюся статистику использовать лишь для контроля порядка возможных потерь.

Очевидно, что угроза причинения ущерба и возникновения бедствия возникает тогда, когда реципиент может подвергнуться воздействию ОЯ, НУП и АКУ. Подверженность реципиента следует рассматривать в пространственном и временном аспекте. Объект воздействия может с той или иной вероятностью оказаться в зоне воздействия ОЯ или вне ее. Поэтому при оценке риска поражения объекта некоторым метеорологическим ОЯ целесообразно сопоставлять площади, охваченные ОЯ, и площадь объекта в пределах рассматриваемой территории действия ОЯ. Данный фрактор отражает вероятность нахождения объекта в зоне действия ОЯ. Наряду с пространственным фактором степень угрозы зависит и от длительности воздействия данного ОЯ. Необходимо также учитывать, что с течением времени степень угрозы может меняться. Так, например, степень подверженности городов угрозе пропорциональна их росту вдоль побережий и другим изменениям инфраструктуры.

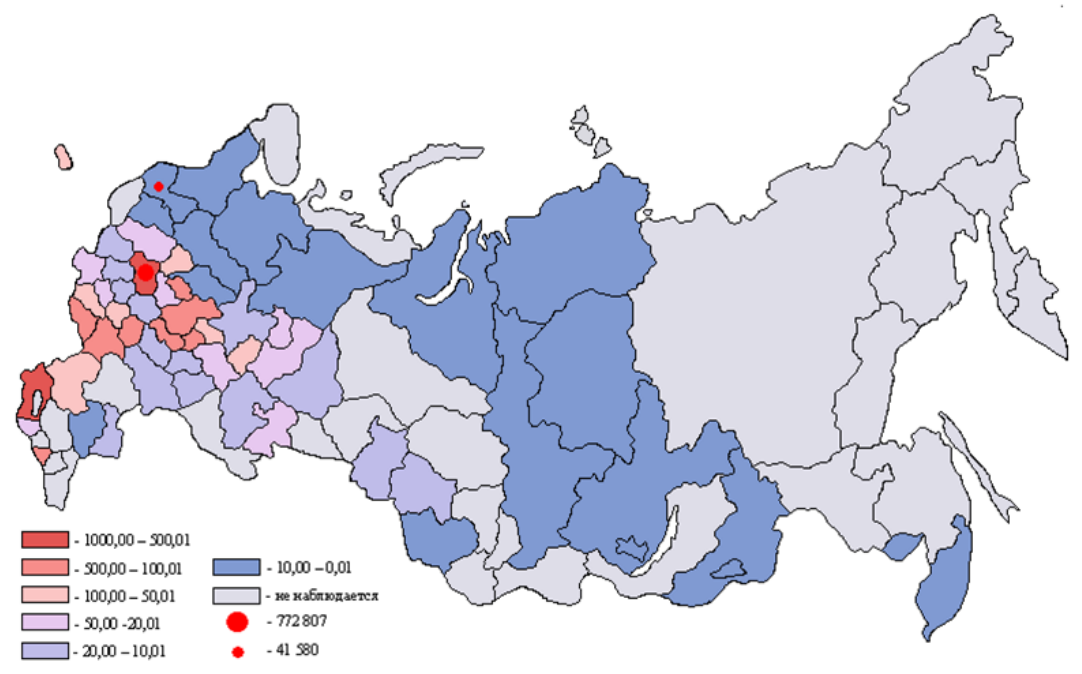

Рис. 4.2 Экономический риск, связанный со смерчами (тыс. руб. в ценах 2010 г.).

\footnotetext{
181 Кобышева Н.В., Кобышев Е.Н., 2001: Районирование территории России по степени опасности смерчей. В кн.: Природные опасности России. Т. 5. Гидрометеорологические опасности, с. 165-167.

182 Кобышева Н.В., 2015: Методика экономического обоснования адаптационных мероприятий, связанных с изменением и изменчивостью климата. Труды Главной геофизической обсерватории им. А.И. Воейкова, вып. 574, с. 5-38.
} 
Исходя из указанных соображений, был разработан косвенный метод расчета уязвимости территории к опасным явлениям ${ }^{183}$, основанный на зависимости уязвимости от степени развития территории, подвергшейся бедствию. Чем более развита экономика, тем больше населения проживает на этой территории и тем больший ущерб возникает при прохождении через нее ОЯ. Уязвимость также зависит от географических $и$ климатических особенностей территории, формирующих определенные характеристики ОЯ. Примером применения этой методики является оценка экономического риска от смерчей для территории России (рис. 4.2).

\section{Оценка допустимости риска}

Когда риск так или иначе определен, для принятия дальнейших действий необходимо оценить его допустимость. Одним из вариантов решения этой задачи является методика, основанная на концепции приемлемого (допустимого) риска. Впервые она была разработана в Нидерландах и начала применяться в практической деятельности на государственном уровне с 1989 г. Для России рекомендован вариант оценки риска ${ }^{184}$, представленный на рис. 4.3. Диаграмма позволяет соотнести число людей, погибших в результате ОЯ, и повторяемость этих явлений. Согласно данному подходу весь спектр значений риска разбивают на 3 области:

- недопустимого (чрезмерного) риска;

- приемлемого риска;

- пренебрежимо малого риска.

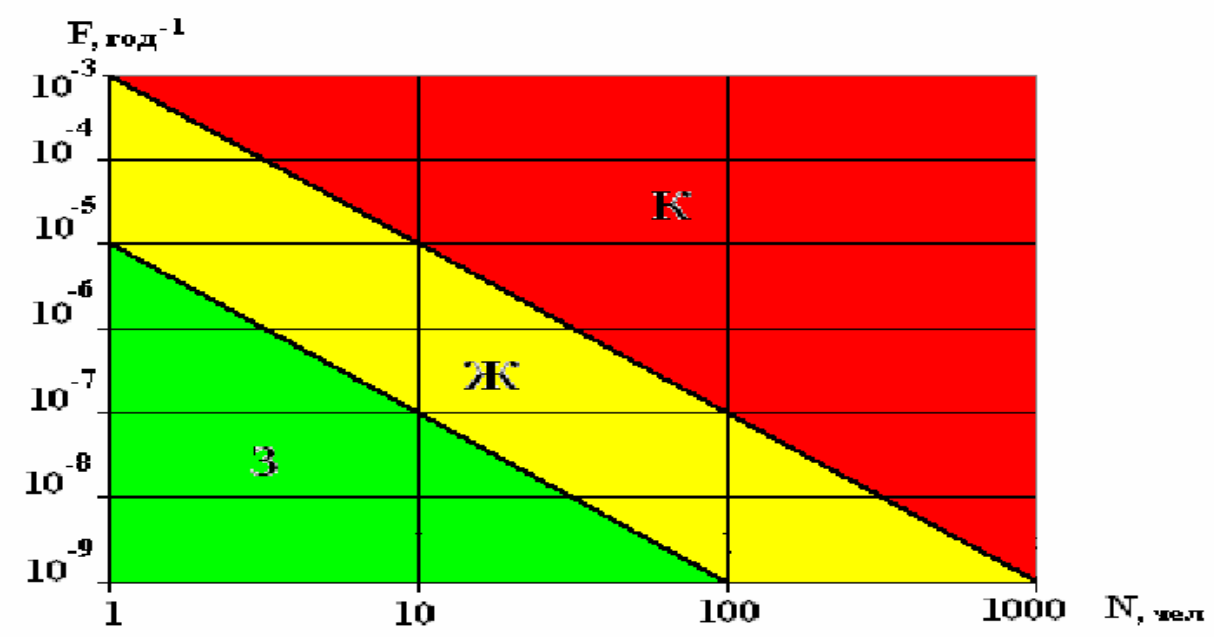

Рис. 4.3 Оценка допустимости риска.

F - частота бедствий; N - число погибших; К (красный) - область чрезмерных рисков; ж (желтый) - область приемлемых рисков; 3 (зеленый) - область пренебрежимо малых рисков.

\footnotetext{
${ }^{183}$ Кобышева Н.В., Акентьева Е.М., Галюк Л.П., 2015: Климатические риски и адаптация к изменениям и изменчивости климата в технической сфере. СПб: «Издательство Кириллица», 214 с.

184 Быков А.А., Акимов В.А., Фалеев М.И., 2004: Нормативно-экономические модели управления рисками. Деловой экспресс, т. 1, № 2, с. 125-137.
} 
При попадании в область чрезмерного риска, любая деятельность, характеризующаяся уровнем риска из этой области, недопустима, даже если она выгодна для общества в целом. В области приемлемого риска принятие решения о допустимости риска является предметом контроля для регулирующего органа в направлении некоторого уменьшения риска. Вопрос об адаптации решается на основе экономических расчетов.

Значения приемлемого риска зависят от комплекса природных, социально-экономических и политических факторов, поэтому в разных странах они различны. В России предельно допустимым уровнем индивидуального риска для человека принято значение в диапазоне $10^{-5}-10^{-4}$, а пренебрежимо малым - $10^{-7}-10^{-6}$. Допустимые значения риска могут различаться в зависимости от объекта. Так, например, для уже существующих зданий и сооружений допустимая величина риска составляет $10^{-4}$, для проектируемых объектов $-10^{-5}$, для атомных электростанций $-10^{-7}$.

В области пренебрежимо малого риска любая деятельность является приемлемой и не требует каких-либо дополнительных усилий по адаптации.

Окончательное решение о критериях допустимости величины риска в данной отрасли или на данной территории должны принимать соответствующие регулирующие органы.

\section{Комплексные риски}

В ряде случаев на реципиента воздействует совокупность опасных процессов (ОЯ, НУП и АКУ), что создает комплексный риск. С другой стороны, иногда даже при воздействии одного опасного явления можно говорить о комплексном риске (например, подъем уровня моря может вызывать одновременно разрушение берега, засоление подземных вод, заболачивание территории и т. д.). Поэтому при анализе рисков для конкретной территории необходимо рассматривать весь комплекс воздействующих факторов и комплекс реципиентов риска. Примером оценки комплексного риска может быть вышеупомянутой проект CliPLivE ${ }^{185}$, в котором климатическая составляющая включала как изменение уровня моря, так и усиление штормов в холодный период года.

Рассматривая методику оценки комплексных рисков, следует подчеркнуть, что климатический риск, создаваемый несколькими ОЯ, часто не является суммой рисков этих ОЯ. Комплексный риск определяется на основе многомерных распределений, составляющих комплекс ОЯ или комплекс последствий. При этом анализируются условные вероятности комплексируемых ОЯ. Этому предшествует исследование физической картины совместного воздействия нескольких возможных ОЯ. Например, если требуется оценить риск недостаточного отопления («недотопа») здания (больницы, детского сада), то помимо температуры следует учитывать также влияние ветра, о чем свидетельствует анализ воздействия метеорологических фракторов на

\footnotetext{
${ }^{185}$ http://cliplive.infoeco.ru/index.php?id=4
} 
отопительный процесс. С этой целью следует составить матрицу двумерного распределения комплекса температуры и ветра, а также матрицу эффрективной температуры. Их совместный анализ показывает, что наибольший охлаждающий эффрект создает не самая низкая температура воздуха и не самый сильный ветер, а сочетание некоторых промежуточных значений температуры и ветра. Данное сочетание можно считать критическим. Вероятностное отклонение от него можно рассматривать как риск «недотопа» (или избыточного отопления - «перетопа»).

Следует также иметь в виду, что для многих ОЯ дополнительную серьезную угрозу представляет так называемый «вторичный» риск. Так, например, вторичный риск сильного дождя связан с последующими наводнениями, размывами насыпей железных и автомобильных дорог и т. д.

При окончательной оценке рисков и принятии решения об адаптации вторичный риск также необходимо идентифицировать и принять в расчет, т. е. использовать системный подход к анализу рисков.

Примером оценки погодно-климатических рисков в региональном масштабе является карта-схема, построенная для территории России (рис. 4.4). При оценке рисков для населения принимались во внимание как характеристики опасных явлений, создающих наибольшую угрозу для жизни и благосостояния населения России по данным МЧС (наводнения, ураганные ветры, лесные пожары), так и социально-экономические показатели (демографическая структура населения, уровень доходов, качество систем раннего предупреждения и т. д.).

Как видно на схеме, наибольшую угрозу для создания ВРП представляют погодно-климатические риски В ЕЧР, прежде всего, в Центральном Федеральном округе, где относительно большая повторяемость и интенсивность опасных явлений сочетаются с наиболее развитой и эфффективной экономикой, а также высокой плотностью населения. Значительные риски для социальной сферы отмечаются в центральных и южных регионах европейской России, а также на юге Сибири и Дальнего Востока.

Управление климатическими рисками в контексте разработки адаптационных стратегий

Эффрективное управление климатическими рисками, базирующееся на результатах их количественной оценки, является одним из основных компонентов при разработке адаптационных мер к нестабильности климата. Можно выделить следующие основные стратегии адаптации к современному и будущему климату:

1) жесткие стратегии - развитие инфраструктуры, более устойчивой к климатическим воздействиям;

2) мягкие стратегии - совершенствование институтов и систем управления: подготовка учреждений по координации откликов на климатические вызовы и поддержке комплексных решений; учет достижений в 
соответствующих областях для разработки современных технических решений; соответствующие финансирование и страхование.

Страхование в настоящее время является одним из основных направлений в управлении рисками. Различные системы страхования являются эффективной мерой передачи и распределения риска, т. к. значительно облегчают процессы восстановления объектов экономики и социальной сферы на территории, подвергшейся воздействию опасного гидрометеорологического явления. Во многих странах мира интенсивно развивается страхование погодных рисков в сельском хозяйстве, в туристическом и жилищном секторах, в здравоохранении и т. д. Так, например, в настоящий момент наблюдается рост осведомленности и интереса к инструментам управления погодными рисками, предлагаемым дочерней компанией AGCS Allianz Risk Transfer (ART), позволяющим компаниям хеджировать данные риски так же, как риски, связанные с колебаниями процентных ставок или курсов обмена валюты. Управление погодными рисками дает компаниям возможность создания индивидуальных стратегий по реагированию на конкретные погодные переменные, способные повлиять на их бизнес. Данные продукты используют независимые погодные данные и привязаны к действительным отклонениям от заранее оговоренных погодных показателей; при выполнении определенных критериев происходит выплата. Очень важно, что в отличие от традиционных страховых продуктов для получения выплаты страхователь не должен обязательно понести физический ущерб. Данные риски измеряются по таким переменным показателям, как температура, атмосферные осадки, солнечная погода и ветер; поэтому при достижении ими определенных заранее заданных уровней автоматически происходит быстрая выплата.

Однако в России система страхования рисков такого типа не развита изза недостаточной материальной базы страховых компаний и значительной неопределенности в оценках погодно-климатических рисков. В связи с этим вопросы объективного анализа рисков приобретают особое значение, т. к. кроме очевидного экономического эффекта оценка погодно-климатического риска, выполненная для страховых компаний, часто служит для привлечения внимания к потенциальной опасности, помогает повысить осведомленность общества и дает новые возможности для управления рисками. Следует, однако, подчеркнуть, что страхование (включая микрострахование) не является универсальным средством для всех типов потерь и ущерба в результате климатических изменений. Варианты страхования могут поддерживать адаптацию и устойчивость к экстремальным погодным условиям, но, как правило, не подходят для многих медленно протекающих климатических изменений.

Исследования показали сложность проблемы климатических рисков и адаптации к изменениям климата. До настоящего времени не решен ряд вопросов фризики воздействия и последствий возникновения опасных климатических условий на объекты хозяйствования. Экономически не обоснованы принципы принятия решений по адаптационным мероприятиям и ряд других серьезных вопросов 


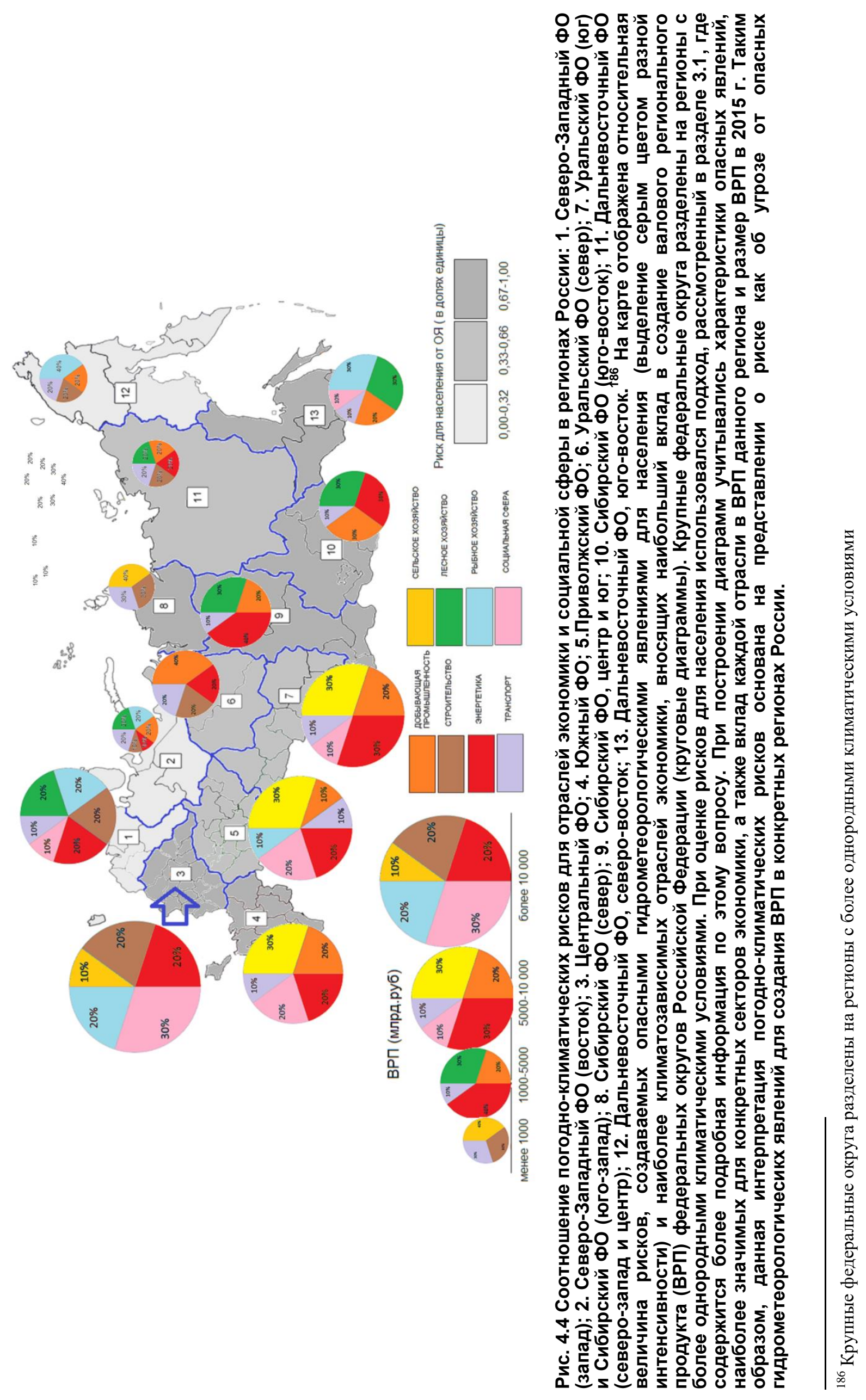




\section{Заключение}

Адаптационный потенциал России, обусловленный размерами ее территории и особенностями современного климата и его ожидаемых изменений, позволяет с некоторым оптимизмом относиться к возможностям приспособления нашей страны (в том числе - упреждающего) к сравнительно «медленным» изменениям климата и связанными с ними глобальным водному и продовольственному кризисам. Однако фрактическую остроту «дефицита» адаптации в России, прежде всего, к экстремальным погодно-климатическим воздействиям, достаточно очевидно продемонстрировали волна тепла 2010 г. на европейской части страны, наводнения в Крымске в 2012 г. и на Амуре в 2013, 2015 и 2016 гг.

Следует подчеркнуть, что к росту ущербов приводят не только погодноклиматические фракторы, но и возрастающая уязвимость инфраструктуры. Это объясняется высокой степенью ее износа, частым несоблюдением строительных норм и правил, освоением территорий, находящихся в зоне повышенного погодно-климатического риска.

Тенденция увеличения разрыва между фрактической и потребной адаптационной способностью или снижения эффеективности адаптации экономики нашей страны к упомянутым изменениям указывает на безотлагательность разработки адаптационных стратегий для регионов и отраслей экономики, не говоря уже о Национальном плане адаптации к наблюдаемым и ожидаемым изменениям климата. ${ }^{187}$ Эти действия предусмотрены и Климатической доктриной Российской Федерации ${ }^{188}$, разработанной Росгидрометом и подписанной Президентом Российской Федерации в 2009 г.

Ключевым инструментом эффективной адаптации является наука. Разработка планов адаптации должна осуществляться с использованием современных методов, позволяющих учитывать неопределенности сценариев климатических изменений, включая изменения статистики опасных погодноклиматических явлений, и соответствующих воздействий (нужно оценивать не только погодно-климатические риски, но и риски, связанные с принятием ошибочных решений).

Задержки в принятии и исполнении государственных решений (в том числе и в отношении разработки планов упреждающей адаптации к изменениям климата) в условиях роста повторяемости опасных погодно-климатических явлений, на которые приходится большая часть чрезвычайных ситуаций, уже в недалеком будущем означают существенное возрастание риска масштабных потерь.

\footnotetext{
187 Катцов В.М., Порфирьев Б.Н., 2017: Адаптация России к изменению климата: концепция национального плана. Труды Главной геофизической обсерватории им. А. И. Воейкова, вып. 586, С. 7-20. ${ }^{188} \mathrm{http}: / /$ kremlin.ru/events/president/news/6365
} 
При этом роль национальной гидрометслужбы при разработке и реализации адаптационных планов всех уровней является одной из решающих. Наблюдения за климатической системой, развитие климатических моделей, прогнозы и перспективные оценки изменений климата и климатических воздействий, а также связанные с ними аспекты управления, обработки и интерпретации данных наблюдений и моделирования представляют собой основу планирования адаптации и последующего мониторинга ее эффрективности. Альтернативы гидрометслужбе в национальной системе адаптации к изменениям и изменчивости климата не существует. 


\section{Основные понятия и определения}

Адаптационный потенциал - способность системы приспосабливаться или быть приспособленной к внешнему воздействию (в частности, к изменению климата или его последствиям, включая экстремальные проявления), с тем, чтобы уменьшить потенциальный ущерб и использовать имеющиеся возможности для извлечения выгод.

Адаптация - процесс приспособления природных, антропогенных или смешанных природно-антропогенных систем, людей и их сообществ, субъектов экономики в ответ на фрактические или ожидаемые воздействия (в частности, климатические), которое позволяет уменьшить вред или использовать благоприятные возможности. Адаптация зависит от чувствительности, уязвимости и меняющейся во времени приспособляемости систем к этим изменениям.

Гидрометеорологическая безопасность - состояние защищенности жизненно важных интересов личности, общества и государства от воздействия опасных природных явлений, изменений климата (Федеральный закон «О гидрометеорологической службе», ст. 1).

Дефицит адаптации - мера недостаточной способности системы противостоять неблагоприятным или использовать благоприятные последствия воздействий (в частности, климатических) в настоящем и/или будущем.

Климатический риск - вероятность (в течение определенного периода времени) существенных нарушений в нормальном функционировании природных, технических и социальных систем вследствие климатического воздействия (в результате изменений или колебаний климата).

Неблагоприятное условие погоды (НУП) - условие погоды, оказывающее негативное воздействие на хозяйственную деятельность, но по своей интенсивности, продолжительности и охвату не достигшее критериев опасного метеорологического явления, установленных в перечне опасных гидрометеорологических явлений, утвержденном Росгидрометом (РД 52.04.5632002 Инструкция. Критерии опасных гидрометеорологических явлений и порядок подачи штормовых сообщений. http://gostfile.ru/gost_pr/rd/rd_52_04_5632002/index.html).

Нематериальный риск - вероятность угроз, для оценки масштаба которых невозможно, либо недостаточно применять стоимостные показатели (например, социальная напряженность, угрозы национальной безопасности и др.)

Опасное гидрометеорологическое явление (ОЯ) - явление, которое по интенсивности развития, продолжительности или моменту возникновения представляет угрозу жизни и здоровью граждан, а также может нанести значительный материальный ущерб. Критерии опасного метеорологического явления установлены в перечне опасных гидрометеорологических явлений, утвержденном Росгидрометом (РД 52.04.563-2002 Инструкция. Критерии 
опасных гидрометеорологических явлений и порядок подачи штормовых сообщений. http://gostfile.ru/gost_pr/rd/rd_52_04_563-2002/index.html).

Распределение рисков - регулирование распределения гражданской ответственности за предотвращение и / или возмещение ущерба, один из способов управления рисками

Реципиент - объект (система объектов), подверженный воздействию (в частности, климатическому).

Управление климатическими рисками - системный и скоординированный процесс принятия и выполнения управленческих решений, в котором климатическая информация используется для снижения климатических рисков и реализации возможностей для повышения устойчивости социальных, экономических и экологических систем.

Уязвимость $к$ изменению климата - степень, в которой объекты (системы) восприимчивы к неблагоприятным последствиям изменения климата и не могут справляться с этими последствиями. Уязвимость является функцией характера, величины и скорости климатических воздействий, которым подвергается данная система, а также ее чувствительности и адаптационного потенциала.

Чувствительность к изменению климата - степень, в которой свойства объекта (системы) изменяются как негативным, так и благоприятным образом в результате климатических воздействий. 
Основные используемые в докладе сокращения

ААНИИ - Арктический и Антарктический научно-исследовательский институт Росгидромета

АЧР - Азиатская часть России

ВМО - Всемирная метеорологическая организация

ВНИИГМИ-МЦД - Всероссийский научно-исследовательский институт гидрометеорологической информации - Мировой центр данных Росгидромета

ГГИ - Государственный гидрологический институт Росгидромета

ГГО - Главная геофизическая обсерватория им. А. И. Воейкова Росгидромета

ГОИН - Государственный океанографический институт им. Н. Н. Зубова Росгидромета

ГРОКО - Глобальная рамочная основа для климатического обслуживания

ЕЧР - Европейская часть России

МГЭИК - Межправительственная группа экспертов по изменению климата

ММГ - многолетнемерзлые грунты

НУП - неблагоприятное условие погоды

ОЯ - опасное (гидрометеорологическое) явление

РКМ - региональная климатическая модель

СНиП - строительные нормы и правила

CMIP - Coupled Model Intercomparison Project

NSIDC - National Snow and Ice Data Center

RCP - Representative concentration pathway

UNISDR - United Nations International Strategy for Disaster Reduction - (Бюро $\mathrm{OOH}$ по снижению риска стихийных бедствий) http://www.unisdr.org/files/7817_UNISDRTerminologyRussian.pdf 


\section{ДОКЛАД \\ О КЛИМАТИЧЕСКИХ РИСКАХ \\ НА ТЕРРИТОРИИ РОССИЙСКОЙ ФЕДЕРАЦИИ}

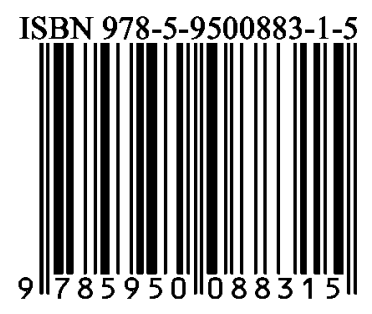

Подписано в печать 28.11.2017 г.

Формат $60 \times 841 \frac{1}{8}$. Гарнитура Times New Roman. Бумага офсетная.

Усл. печ. л. 12,32. Тираж 150 экз. Заказ № 13/28117.

Отпечатано в соответствии с предоставленными материалами в ООО «Амирит», 410004, г. Саратов, ул. Чернышевского, 88.

Тел.: 8-800-700-86-33 | (845-2) 24-86-33

E-mail: zakaz@amirit.ru

Сайт: amirit.ru 